\title{
AN ASSESSMENT OF WETLAND IMPACTS AND COMPENSATORY MITIGATION IN THE CUYAHOGA RIVER WATERSHED, OHIO, USA
}

\author{
A Thesis \\ Presented in Partial Fulfillment of the Requirements for the \\ Degree Master of Science in the \\ Graduate School of The Ohio State University
}

By

Chad Isaac Kettlewell, B.S.

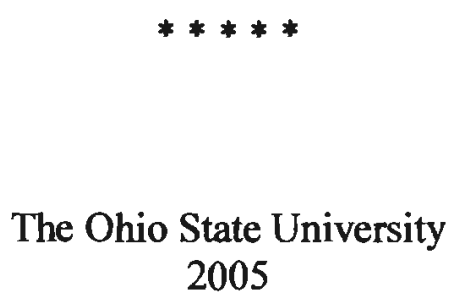

2005

Master's Examination Committee:

Dr. Virginie Bouchard, Adviser

Dr. Steven Gordon

Dr. Dale White

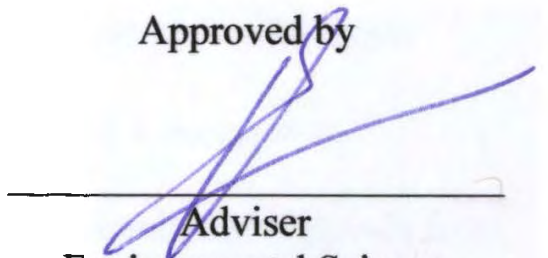

Environmental Science 


\section{ABSTRACT}

Current federal and state regulations allow wetlands to be destroyed as long as impacts are mitigated through restoration, creation, enhancement, or preservation of additional wetlands. In this research, we explore how effective these regulations are and if any cumulative changes to wetland and landscape structure are occurring as a result of wetland policy. A watershed-based assessment of wetland impacts and compensatory mitigation was conducted for the Cuyahoga River watershed in northeastern Ohio, USA. Twenty-three Section 401 certifications and Ohio Isolated Wetland permits were evaluated with regards to permit compliance, wetland structure, and landscape context. Although there was a net gain in wetland area as a result of the 23 permits, the Cuyahoga River watershed experienced a net loss of wetlands due to the exportation of mitigation. The majority of projects $(67 \%)$ that restored or created wetlands independently (not at a mitigation bank) were not successful at meeting permit requirements. The comparison of impacted and mitigation wetland vegetation types revealed an increase in emergent and open water wetland area and a decrease in scrub/shrub and forested wetlands. There was a decrease in the number of wetlands from impacted wetlands (134) to mitigation wetlands (65). Impacted wetlands were also significantly smaller than replacement wetlands $(p=0.027, d f=74, t=2.26)$. Landscape composition was variable for the 9 mitigation projects that were evaluated, varying from 
17-75\% natural land uses and from $18-82 \%$ human land uses.

Results indicate that an improvement in compliance with permit requirements is necessary. Current wetland policy allows for the exportation of wetlands for mitigation purposes which can result in the loss of wetland function from some hydrologic units. The consideration of wetland structure needs to be incorporated into the regulatory process in order to avoid a shift in wetland types that are present. Instead of reviewing projects on a site-by-site basis, a landscape approach should be taken in order to avoid the loss of upland-wetland heterogeneity and the placement of wetlands in harsh landscapes which could potentially threaten wetland function. 
For Mom and Dad

Thanks for everything you've done to make all of this possible 


\section{ACKNOWLEDGMENTS}

I would like to thank my advisor, Virginie Bouchard, for her endless knowledge, support, and patience.

I thank Steven Gordon and Dale White for their assistance with planning, development, and revision of this research and thesis.

I am grateful to Mick Micacchion, John Mack, and Laura Fay from The Ohio Environmental Protection Agency for their support and the opportunity to conduct this research.

I am indebted to Deni Porej for the use of data from a previous report to the Ohio Environmental Protection Agency as well as continued support and friendship.

I would also like to thank many others from The Ohio Environmental Protection Agency for their varied contributions: Randy Bournique, Jeff Boyles, Pete Clingan, Art Coleman, Brian Gara, Michelle Hammond, Dan Osterfeld, Mike Smith, Dave White, and Barb Wooldridge.

I owe thanks to all of those who helped me with fieldwork, planning, and revision, especially Chris Anderson, Janice Gilbert, Kyle Herrman, Katie Hossler, Kelly Powell, Abby Rokosch, Erin Rothman, and Kyle Snowdon.

This research was supported by the United States Environmental Protection Agency grant number CD97576201-0 and the Ohio Environmental Protection Agency. 


\section{VITA}

June 8, 1981 Born - Zanesville, Ohio, USA 2003 B.S. Natural Resources, The Ohio State University $2003-2005$ Graduate Research and Teaching Associate, The Ohio State University

\section{FIELD OF STUDY}

Major Field: Environmental Science 


\section{TABLE OF CONTENTS}

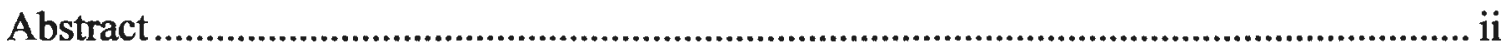

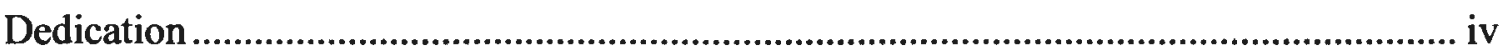

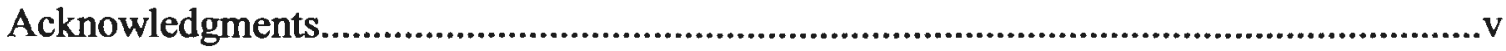

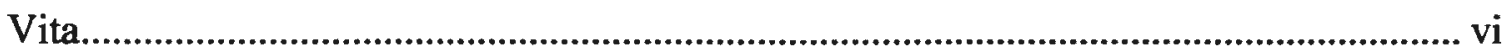

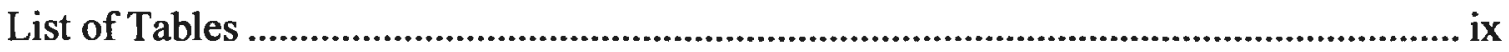

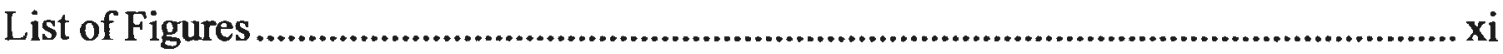

Chapters:

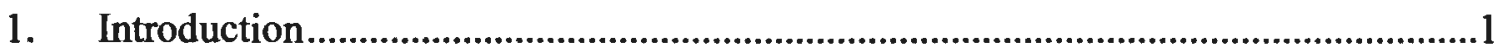

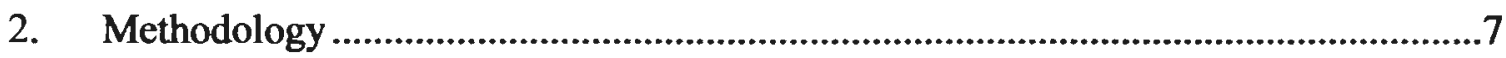

2.1 Wetland and Permit Assessment..................................................................

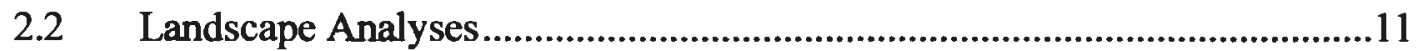

2.2.1 Wetland Spatial Configuration ....................................................14

2.2.2 Composition of Surrounding Landscapes........................................16

2.2.3 Amphibian Potential ...................................................................18

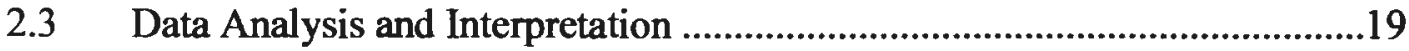

$2.4 \quad$ Wetland Restoration Potential ................................................................20

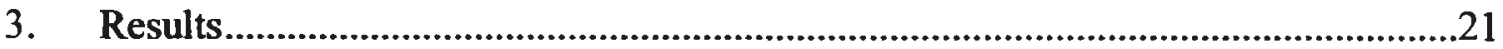

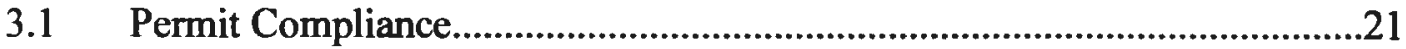

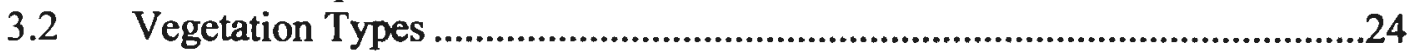

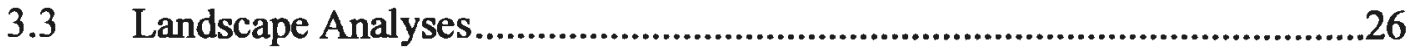

3.3.1 Generic Versus Actual Landscapes ...........................................26

3.3.2 Wetland Spatial Configuration ....................................................27

3.3.3 Composition of Surrounding Landscapes.....................................28

3.3.4 Amphibian Potential .......................................................................32

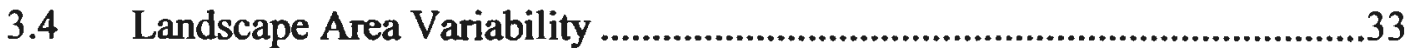




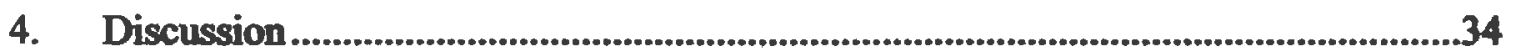

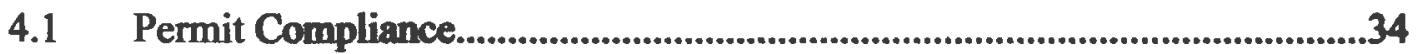

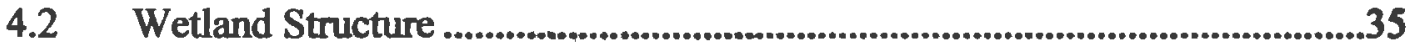

4.3 Composition of Surrounding Landscapes ...........................................................37

4.4 Amphibian Potential ........................................................................................ 38

4.5 Restoration Potential ...........................................................................................39

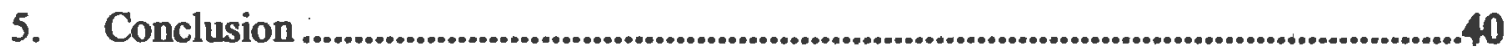

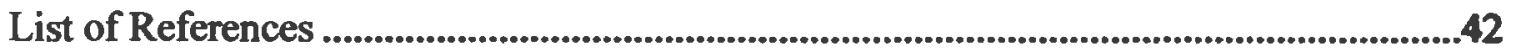

Appendix A - Project Locations......................................................................................47

Appendix B - Project Analyses and Special Considerations .............................................49

Appendix C - Analysis of Generic Landscapes Using FRAGSTATS ...............................53

Appendix D - Landscape Metric Equations ......._.............................................................58

Appendix E - Land Use Classes and Digitization Protocol ..................................................61

Appendix F - Landscape Areas .................................................................................................63

Appendix G - Landscape Use Maps...........................................................................66

Appendix H - Pearson's Correlations for Landscape Indices .........................................75

Appendix I - Pearson's Correlations for Landscape Area...................................................81

Appendix J - Permit Compliance ..........................................................................................83

Appendix K - Wetland Structure Data .................................................................................88

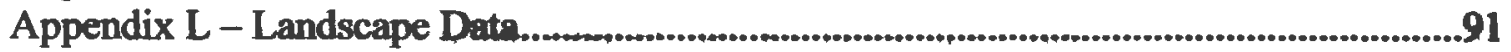

Appendix M - Restoration Potential Data ..................................................................................102 


\section{LIST OF TABLES}

Table

Page

2.1 Landscape metrics that were used for each amphibian potential scenario

3.1 Vegetation types by wetland area for impacted and mitigation wetlands .25

3.2 Land uses percentages for each project 29

3.3 Results for amphibian habitat potential analysis 32

A.1 Latitude and longitude coordinates for impacted and mitigation wetlands for each project .48

B.1 Analyses that were conducted for each project 50

B.2 Special circumstances that were noted during delineation of mitigation wetlands and calculation of permit compliance

E.1 Descriptions of land use classes used for landscape analysis

F.1 Area of landscapes for impacted wetlands $(1000 \mathrm{~m})$ 64

F.2 Area of landscapes for mitigation wetlands (300 m) 64

F.3 Area of landscapes for mitigation wetlands $(1000 \mathrm{~m})$..........................................65

H.1 Pearson's correlations (r) for $300 \mathrm{~m}$ land use percentages ....................................76

H.2 Pearson's correlations (r) for $1000 \mathrm{~m}$ land use percentages .................................77

H.3 Pearson's correlations ( $r$ ) for $300 \mathrm{~m}$ landscape metrics by land use class.............78

I.1 Pearson's correlations (r) for landscape sizes (ha) and all landscape metrics .82

J.1 Data for wetland impacts and mitigation used for calculation of permit compliance and net gain/loss of wetland area. .84 
K.1 Area of vegetation types for wetland impacts and mitigation for all projects that created or restored mitigation wetlands independently

K.2 Size (ha) of impacted wetlands

K.3 Size (ha) of mitigation wetlands ..........................................................................89

K.4 Number of impacted and mitigation wetlands for each project.............................90

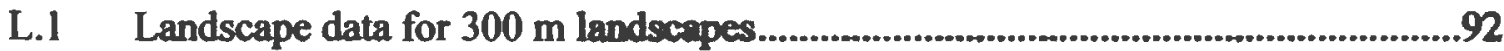

L.2 Landscape data for $1000 \mathrm{~m}$ landscapes................................................................97

L.3 Percent of human, natural, and surface water land uses on mitigation Landscapes.

M.1 Compliance (\% deviation from required mitigation) and restoration potential data 


\section{LIST OF FIGURES}

Figure

Page

2.1 Map of study area and locations of impacted and mitigation wetlands associated with the 23 Section 401 and Ohio Isolated Wetland permits .8

$2.21000 \mathrm{~m}$ land use map for project \#6.

3.1 Area of wetlands that were mitigated in the Cuyahoga River watershed and wetland area that was exported from the watershed .23

3.2 Percent deviation from the required mitigation wetland area..............................23

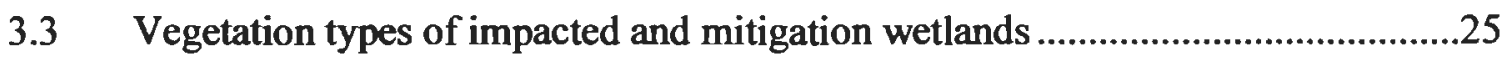

3.4 Size-ranked display of all impacted and mitigation wetlands .............................28

3.5 Combined land use percentages for $300 \mathrm{~m}$ landscapes........................................30

3.6 Combined land use percentages for $1000 \mathrm{~m}$ landscapes........................................31

C.1 Generic landscapes that were used to test the behavior of FRAGSTATS metrics for general landscape composition and amphibian potential analysis

C.2 Results for four different landscape metrics using the generic landscapes shown in Figure C.1.

C.3 Generic landscapes that were used to test FRAGSTATS metrics for wetland spatial configuration analysis

C.4 Results for four different landscape metrics using the generic landscapes shown in Figure C.3

G.1 $1000 \mathrm{~m}$ land use map for project \#1

G.2 $1000 \mathrm{~m}$ land use map for project \#2 ............................................................68

G.3 $1000 \mathrm{~m}$ land use map for project \#3 
G.4 $1000 \mathrm{~m}$ land use map for project \#4.

G.5 $1000 \mathrm{~m}$ land use map for project \#5a...........................................................................71

G.6 $1000 \mathrm{~m}$ land use map for project \#5b.............................................................72

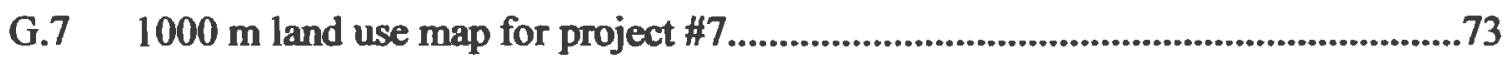

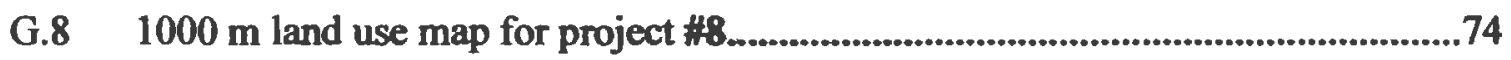




\section{CHAPTER 1}

\section{INTRODUCTION}

In the United States, under Sections 401 and 404 of the Clean Water Act (CWA), unavoidable impacts to wetlands must be mitigated through creation, restoration, enhancement, or preservation of wetlands. In the state of Ohio, the Ohio Environmental Protection Agency (OEPA) is responsible for issuing Section 401 certifications for impacts to wetlands that are connected to "navigable waters." Navigable waters fall under federal jurisdiction, so impacts to these waters require a permit from the federal and state governments. The OEPA also issues Ohio Isolated Wetland permits for impacts to those wetlands that do not fall under federal jurisdiction (i.e., isolated wetlands). When impacts to wetlands are permitted, they must be mitigated through the creation, restoration, enhancement, or preservation of additional wetland area. Wetland creation is the establishment of wetland in an upland area. Wetland restoration is the reestablishment of a wetland that has been previously eliminated by drainage or fill. Wetland enhancement includes any activity which improves the quality of a degraded wetland and wetland preservation is the legal protection of wetlands from future impacts. A host of research papers have been published regarding the success of compensatory wetland mitigation in the United States (e.g., Allen and Feddema 1996, Robb 2000, Brown and Veneman 2001, Cole and Shafer 2002, Morgan and Roberts 2003, Porej 
2003, Kettlewell 2005). Mitigation success is generally measured by evaluating compliance with permit requirements or by comparing mitigation wetlands to natural "reference" wetlands (Mitsch and Wilson 1996, Ambrose 2000, Kentula 2000).

Studies that assess compliance with permit requirements generally evaluate wetland area and to a lesser extent, wetland vegetation. These studies tell us whether a net gain of wetlands is occurring and also what types of wetlands are being successfully constructed (e.g., marsh, floodplain, scrub/shrub). Research that evaluates the function of mitigation wetlands is less common (Ambrose 2000). Functional evaluations have been conducted on a smaller scale by comparing natural reference wetlands with mitigation wetlands (e.g., Simenstad and Thom 1996, Zampella and Laidig 2003). Few assessments have compared the wetlands that were impacted with the mitigation wetlands that replaced them (see Cole and Shafer 2002 and Minkin and Ladd 2003). Such comparisons are the ideal approach to understanding whether or not mitigation policy is effective (Zedler 1996). In order to understand what changes in wetland area, structure, and function have occurred within a region as a result of mitigation efforts, we must compare what is being lost to what is being produced.

Recent publications have also emphasized the need for a watershed-based approach for research and management related to wetlands (Bedford and Preston 1988, Zedler 1996, ELI 2004). Watershed and landscape based approaches are recommended because many wetland functions can be affected by conditions and activities in the surrounding landscape (Mitsch and Gosselink 2000, Amezaga and others 2002). Despite this understanding, few studies of wetland mitigation have taken such an approach (but see Kelly 2001). The lack of studies with a watershed or landscape based approach may 
be due to the fact that many mitigation projects are conducted on a site by site basis, without considering the broader landscape (Bedford and Preston 1988, Race and Fonseca 1996). There is concern that wetland impacts and mitigation efforts are resulting in a spatial re-configuration of wetlands within the landscape (Bedford 1996, Kelly 2001). This re-configuration could include changes in 1) the spatial extent of wetlands including size, number, and location, 2) wetland characteristics such as hydrogeomorphic (HGM; Brinson 1993) class or vegetation type, and 3) land uses surrounding wetlands. HGM is a classification system for wetlands that focuses on hydrologic and geomorphic controls (Brinson 1993). Such re-configuration can be expected to have an impact upon the functions that wetlands are able to provide within the landscape (Tilton 1995, Faulkner 2004). Mitsch and Gosselink (2000) have predicted that wetland value to humans becomes the greatest when the landscape surrounding wetlands is comprised of both natural and human land uses. If human land uses become extremely dense, the impacts upon wetland water quality can be severe and wetland value will suffer as a result of functional decline. However, the use of such generalizations should be done with care. There are undoubtedly many wetland functions that can provide optimal benefit to human society within an urban setting. Other wetland functions, such as providing habitat to certain wetland dependent species, require a more natural setting. For example, research has shown that some amphibian species such as the mole salamanders (Ambystoma spp.) and wood frogs (Rana sylvatica) require large core areas of forest and wetland habitat (Semlitsch and Bodie 2003, Colburn 2004). Amphibians are good indicators of ecosystem health due to their permeable skin, biological, and life history characteristics (Hecnar 2004). The presence of urban land has been shown to have negative correlations 
with these species (Findlay and Houlahan 1996, Knutson and others 1999, Houlahan and Findlay 2003). Many of these species are maintained within metapopulations requiring a heterogeneous forest-wetland landscape for population survival. A metapopulation is a group of subpopulations that are maintained through the active exchange of individuals between subpopulations (Molles 2002). Amphibians serve as one example where landscape composition is important for wetland function. Landscape effects upon other wetland characteristics include exotic plant species (Ehrenfeld and Schneider 1991), bird communities (Croonquist and Brooks 1993), and water quality variables (Houlahan and Findlay 2004).

A complete assessment of wetland mitigation would include an evaluation of compliance with permit requirements and a comparison of wetland functions between impacted wetlands and replacement wetlands. A watershed-based approach should be taken to include an evaluation of the spatial configuration of wetlands in the landscape as well as an evaluation of surrounding land use effects upon wetland characteristics. In review of wetland mitigation literature from 1993 to present, only one publication was found which has taken such an approach (Johnson and others 2002). One difficulty in this type of assessment is the analysis of wetland function, especially for impacted wetlands because they have already been eliminated for development. Instead, we have to rely upon information that has already been collected for these wetlands prior to their destruction. Such information lies mostly within assessment reports that are submitted for Section 401 certifications and Ohio Isolated Wetland permits. Information within these reports is generally limited to structural components, especially vegetation descriptions. Johnson and others (2002) noted that their functional comparison of 
impacted and mitigation wetlands was particularly subjective in nature due to a lack of information about wetlands that had already been destroyed. If subjectivity is to be avoided, the comparison of impacted wetlands and mitigation wetlands is limited to the level of information that is contained within Section 401 and Ohio Isolated Wetland permit files.

The purpose of this study was to conduct an assessment of wetland mitigation using the approach outlined above. The structure of the assessment included an evaluation of permit compliance, a comparison of impacted and mitigation wetlands, an analysis of wetland configuration and situation in the landscape, and a watershed-based approach. The lack of data on impacted wetlands limited the comparison of impacted and mitigation wetlands to strictly structural metrics. The Cuyahoga River watershed (CRW) in northeastern Ohio, USA was chosen as the study area for the assessment. The CRW covers an area of $2,106 \mathrm{~km}^{2}$ of both urban and rural areas including a portion of the Cuyahoga Valley National Park (USEPA 2003). Twenty-three Section 401 and Ohio Isolated wetland permits that were issued between January 1, 1995 and January 1, 2003 were evaluated. More specifically, the objectives of the study were to

1) Assess the level of compliance with permit requirements and net gain/loss of wetland area for each permit and within the watershed

2) Determine whether any changes in wetland structure have occurred as a result of wetland impacts and mitigation efforts

3) Describe the landscape setting of mitigation wetlands with respect to human and natural land uses

4) Assess the potential of mitigation landscapes to support a specific function - amphibian habitat 
Mitigation locations were also compared to a study of wetland restoration potential for the CRW conducted by White and Fennessy (2005) in order to compare site selection with compliance success rates. 


\section{CHAPTER 2}

\section{METHODOLOGY}

\subsection{Wetland and Permit Assessment}

The Section 401 certifications and Ohio Isolated Wetland permits issued by the Ohio Environmental Protection Agency (OEPA) for impacts to surface waters within the Cuyahoga River watershed were reviewed. Only those permits which required mitigation for impacts to wetlands were considered. Additionally, only permits that were issued between January 1, 1995 and January 1, 2003 were selected. In order to allow sufficient time for wetland characteristics to develop, the permits for which mitigation wetland construction was not completed before January 1, 2003 were excluded. Twenty-six permits fit these criteria. Two permits were excluded because only temporary impacts were permitted and mitigation requirements were constrained to the re-establishment of wetland within the impacted area. One additional permit was excluded because existing wetlands adjacent to the mitigation wetland made it impossible to determine the location of the mitigation boundary. The remaining twenty-three permits provided the basis for this study (Figure 2.1; Appendix A). 


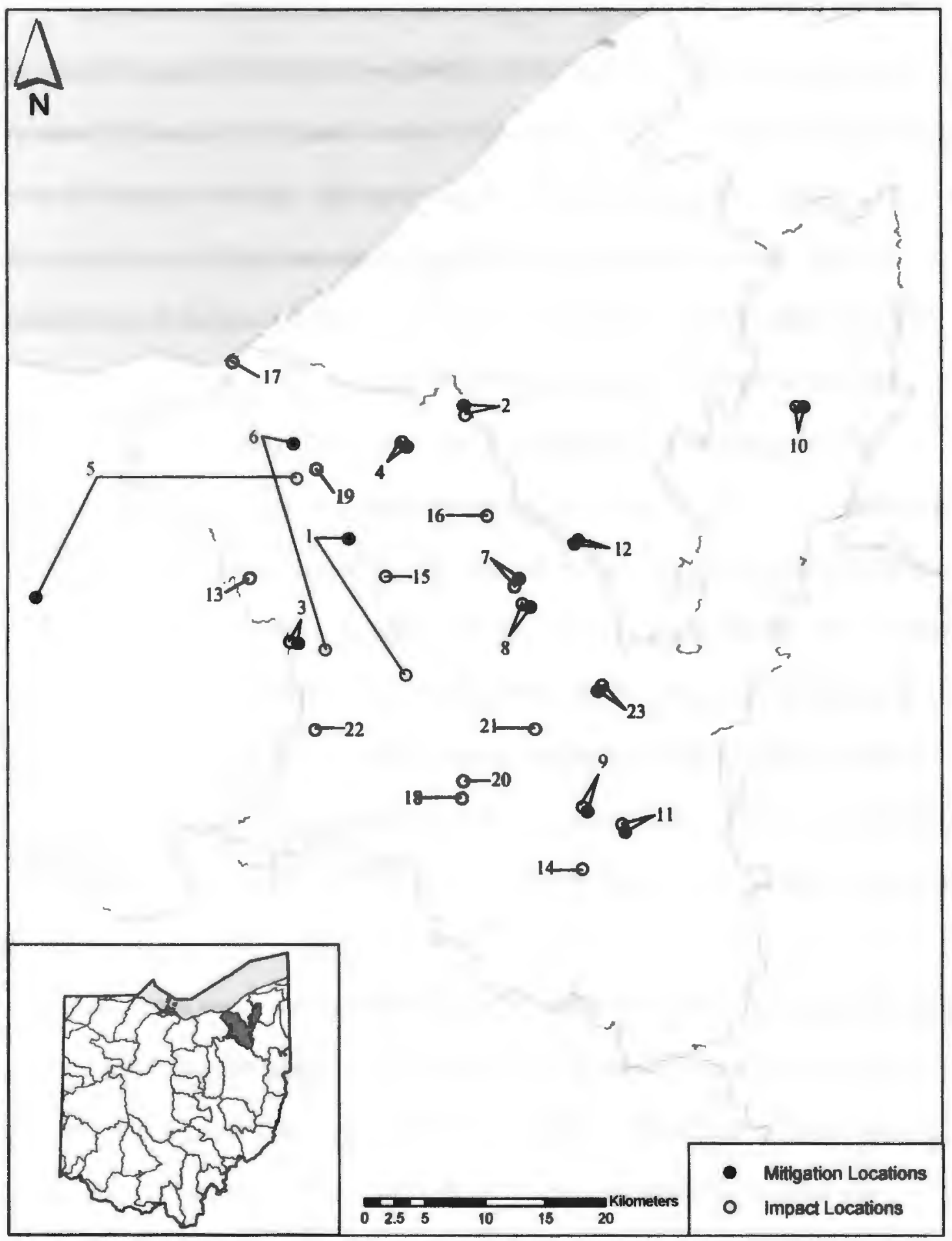

Figure 2.1 Map of study area and locations of impacted and mitigation wetlands associated with the 23 Section 401 certifications and Ohio Isolated Wetland permits. 
Information regarding the area and the type of vegetation of impacted wetlands was taken from permit files made available to me by the OEPA. These permits also contained the amount of required wetland mitigation and maps showing the location and extent of impacted wetlands. Information provided by the applicant was used to determine the area of open water/submergent, emergent, scrub/shrub, and forested wetland for each impacted wetland. Open water/submergent vegetation was defined as wetland area where there was no vegetation emerging above the surface of the water. Emergent vegetation wetland was dominated by herbaceous plants that were either emerging above the surface of the water or growing directly out of the soil. Scrub/shrub vegetation wetland was dominated by shrub species that were either emerging above the surface of the water or growing directly out of the soil. Forested vegetation wetland was dominated by tree species that were either emerging above the surface of the water or growing directly out of the soil. Many applicants failed to discriminate between open water/submergent and emergent wetland area, so these two categories were combined for analysis. Applicants and consultants were contacted in order to gain access to mitigation wetland sites.

Field work was conducted between June 1, 2004 and October 1, 2004 to delineate areas and assess vegetation type for each mitigation wetland. These data were then compared with the data concerning impacted wetlands to 1) calculate net gain or loss of wetland area 2) determine compliance with permit requirements and 3) assess any changes in vegetation types as a result of mitigation efforts. Percentage of vegetation types (open water/submergent, emergent, scrub/shrub, and forest) were visually estimated in the field for each mitigation wetland. Even with previous experience ( 3 years) in 
estimating wetland vegetation percentages, it is possible that some error may have been introduced by using this method. In order to verify that estimations were acceptable measures, aerial photographs were consulted and compared with vegetation estimates for two wetlands. Nonetheless, this measurement is subjective and should be treated as an estimate of wetland vegetation. Additionally, vegetation types could change over time as wetlands evolve. Mitigation wetlands were delineated using the United States Army Corps of Engineers 1987 wetland delineation procedure (USACOE 1987). Wetland boundaries were mapped using the Trimble ${ }^{\circ}$ GeoXT handheld Global Positioning System (GPS). To standardize coordinate data collection, a point was taken at each location where the wetland boundary turned $10^{\circ}$ or more (based upon visual estimation). Point data were later processed and differential correction was conducted using stationary files from the nearest base station. Boundary data were then imported into ArcGIS ${ }^{\circ}$ software (ESRI, Inc.) and converted to polygons in order to calculate wetland area. A portion of the mitigation wetlands for one project - project \#12 - was created as 23 forested vernal pools. GPS data for these 23 created vernal pools could not be collected due to heavy forest canopy. The areas of these wetlands were calculated by scanning and geo-referencing an as-built survey within ArcGIS. The as-built survey was created by the applicant using standard surveying techniques to map the outline of the vernal pools. Polygons were then created for each vernal pool and area was calculated. The vernal pools accounted for 0.299 ha while other wetlands for project \#12 which were calculated with GPS accounted for 1.221 ha. A list of the analyses that were conducted for each project along with any special considerations that were necessary is located in Appendix B. 
During delineation of mitigation wetlands, two problems were encountered which resulted in an over-estimation of wetland area: 1) presence of deep open water habitat and 2) wetlands that were present on the mitigation site before wetland construction began. Two mitigation sites contained deep open water habitat which was fringed by emergent and submergent vegetation wetland. It was impractical to delineate the open waterwetland boundary given time and methodological constraints. Although the open water areas would not normally be counted for wetland mitigation credit by OEPA, they were included in this study. Additionally, at three other sites, project maps revealed wetlands that were located adjacent to or within mitigation wetland boundaries. Essentially, existing wetlands were expanded during the mitigation construction process. Because the boundary between the natural and mitigation wetlands was not clear, these areas were also included with mitigation area. Although rough estimates of these areas were possible, they would have introduced unwanted assumptions and inconsistencies in the scale of data collection. A mitigation inventory prepared for OEPA includes estimates of the open water areas and existing wetlands that were not considered in this study (Kettlewell 2005).

\subsection{Landscape Analyses}

Landscapes were analyzed with the intention of answering three questions: 1) has mitigation caused a shift in wetland spatial configuration, 2) what is the general composition of the landscape, and 3) based upon the landscape composition, what is the potential of mitigation sites to support certain amphibian species? Wetland spatial configuration was defined as the number, size, and distance between wetlands on a 
project site. Landscape composition was defined as the amount of different land uses that were present surrounding mitigation wetlands. The FRAGSTATS Spatial Pattern Analysis Program, Version 3.3 (McGarigal and others 2002) was used to assess wetland spatial configuration and landscape composition. FRAGSTATS calculates a suite of metrics for landscape data that are represented in raster form.

For each of the three questions listed above, generic landscapes were created in order to analyze the behavior of different landscape metrics provided by FRAGSTATS. Results from the generic landscapes along with a review of the literature were used to select several class-level metrics for each portion of landscape analysis. Class-level metrics are calculated by averaging the metric values of each patch for a specific land use. All generic landscapes were created using a landscape area of 4.16 ha and cell size of $3.048 \mathrm{~m}$. The landscape area (4.16 ha) reflects the size of a landscape around the average size of mitigation wetlands ( $0.4 \mathrm{ha})$ using a $300 \mathrm{~m}$ buffer to create the landscape boundary. A cell size of $3.048 \mathrm{~m}$ was used to remain consistent with the average minimum width of patches in actual landscapes. For comparison of wetland spatial configuration of impacted versus mitigation wetlands (Question 1 above), 12 indices were analyzed using four different wetland configurations (Appendix C). Of these 12 indices, patch density (\# wetlands/100 ha) was chosen because it distinguished between many, clustered wetlands and few, scattered wetlands well. For questions 2 and 3 above, 12 indices were analyzed using five different landscapes (Appendix C). For general landscape description (Question 2 above), percent of landscape was chosen because it gave a direct description of the amount of land uses within landscape. The percent of landscape metric is found by taking the sum of the area of all patches of a particular land 
use and calculating what percentage of the landscape that land use comprises. For amphibian potential (Question 3 above), percent of landscape for each land use, radius of gyration, and proximity index were selected. Radius of gyration can be interpreted by visualizing an organism that is placed and travels randomly within a patch (Neel and others 2004). The radius of gyration is the average distance that the organism can travel and remain within the focal patch. The proximity index, developed by Gustafson and Parker (1992), is an index that measures both the size and proximity of patches of the same land use that are within a specified search distance of the focal patch (McGarigal and others 2002). The index is measured for each patch (focal patch) of a certain land use and then averaged, giving a single value for each land use. Proximity increases as the distance to other patches of the same land use decreases and as the contiguity of those patches increases. For this study, a search distance of $300 \mathrm{~m}$ was used for proximity index so that all patches of the same land use would be considered by FRAGSTATS. The equations for landscape metrics that were used are located in Appendix D.

Landscapes were created by using the buffer tool within ArcGIS ${ }^{\circ}$ (ESRI, Inc.) to measure a distance of $300 \mathrm{~m}$ and $1000 \mathrm{~m}$ from the edge of mitigation wetlands. As a result, there were two landscapes for each mitigation wetland. The availability of high resolution aerial photographs proved to be the limiting resource for digitizing land uses (used for Questions 2 and 3). This was not a factor for Question 1 because only wetland land uses (impacted and mitigation wetlands) were used for the calculation of wetland spatial configuration. Aerial photographs were only available for recent years. Since wetland impacts occurred 2 to 8 years ago, these photographs were not a reliable source of landscape composition around impacted wetlands. As a result, it was impossible to 
make a comparison impacted and mitigation landscapes. County level aerial photos with six inch $(15.24 \mathrm{~cm})$ cell sizes were used to digitize land uses into thirteen different classes: agriculture, construction, forest, industrial, mitigation wetland, mowed, oldfield, park, pond, residential, road, waterway, and wetland. Oldfield was defined as early successional, upland, herbaceous vegetation which was generally present in areas that were human land use and recently abandoned. Six inch $(15.24 \mathrm{~cm})$ resolution, county level aerial photos taken between 2000 and 2002 were. Appendix E contains a list of different land uses which were included within each class. Some wetlands, especially small, forested wetlands, may have been inadvertently excluded due to low visibility in aerial photos. Land uses were digitized using ArcGIS ${ }^{\circ}$ (ESRI, Inc.) at a map scale of 1:2000-1:4000. Ten feet $(3.048 \mathrm{~m})$ was the approximate average minimum width of digitized land uses. Land use areas were converted from vector to raster format using a $3.048 \mathrm{~m}$ cell size in order to remain consistent with the minimum width of land use polygons. Raster files were then converted to ASCII text files for use within FRAGSTATS. Raster and ASCII files were reviewed in order to remove stray cells which would be treated as a single patch by the FRAGSTATS software.

\subsubsection{Wetland Spatial Configuration}

The number and size of impacted wetlands were compared with mitigation wetlands using information from permit files (for impacted wetlands) and GPS data (for mitigation wetlands) for all 23 projects (Question 1). Comparisons were made for the sum of all impacted and mitigation wetlands as well as for impacted versus mitigation wetlands for each project. Although some mitigation banks sell wetland credits for more 
than one wetland, they do not specify exactly where these credits are located within the bank. For the 8 projects in this study that utilized a mitigation bank, it was assumed that wetland credits were located within a single wetland. For independent projects $(n=12)$, the spatial configuration of impacted wetlands was compared to that of mitigation wetlands on a per-project basis using patch density (\# wetlands/100 ha) within FRAGSTATS. This analysis did not include any land uses other than impacted and mitigation wetlands. Impacted wetland polygons were created by scanning and georeferencing projects maps supplied by the permit holder. The scale and quality of these maps were variable. However, the sizes of wetlands were verified by the Army Corps of Engineers during field investigations before impacts were allowed. The ACOE - verified wetland sizes were compared with digitized wetland sizes to ensure that maps were accurate. Any error that was introduced by using the project maps would have been small and had very minimal effects upon the results of this study. Mitigation polygons were created using GPS data collected in the field (and digitized vernal pool polygons for project \#12 as described above). Landscapes (with only impacted and mitigation wetland land uses) were created for each impact and mitigation site using a buffer of $1000 \mathrm{~m}$ from wetland edges for all twelve independent projects. The area of $1000 \mathrm{~m}$ landscapes surrounding impacted wetlands varied from 44.3 to 115.8 ha while the area of $1000 \mathrm{~m}$ landscapes surrounding mitigation wetlands varied from 45.6 to 57.4 ha (Appendix F). Mitigation wetlands were constructed at two different locations for project \#5. Patch density for the two mitigation locations associated with this project were combined for this portion of analysis. 


\subsubsection{Composition of the Surrounding Landscape}

For a general description of land uses (Question 2) surrounding mitigation sites (n $=9$ ), landscapes were created using buffers of $300 \mathrm{~m}$ and $1000 \mathrm{~m}$ from the edge of mitigation wetlands (Figure 2.2). The area of $300 \mathrm{~m}$ landscapes surrounding mitigation wetlands varied from 5.55 to 8.88 ha (Appendix F). Analysis was only feasible for eight of the twelve projects because high resolution aerial photographs were not available for Geauga and Portage Counties, where 4 projects were located. During this portion of analysis, the two mitigation locations for project \#5 analyzed separately. Land use classes were collapsed into human, natural, and surface water categories in order to gain an understanding of the overall landscape setting of mitigation wetlands. The number of wetlands located within the landscape was compared between $1000 \mathrm{~m}$ and $300 \mathrm{~m}$ landscapes for each project. 


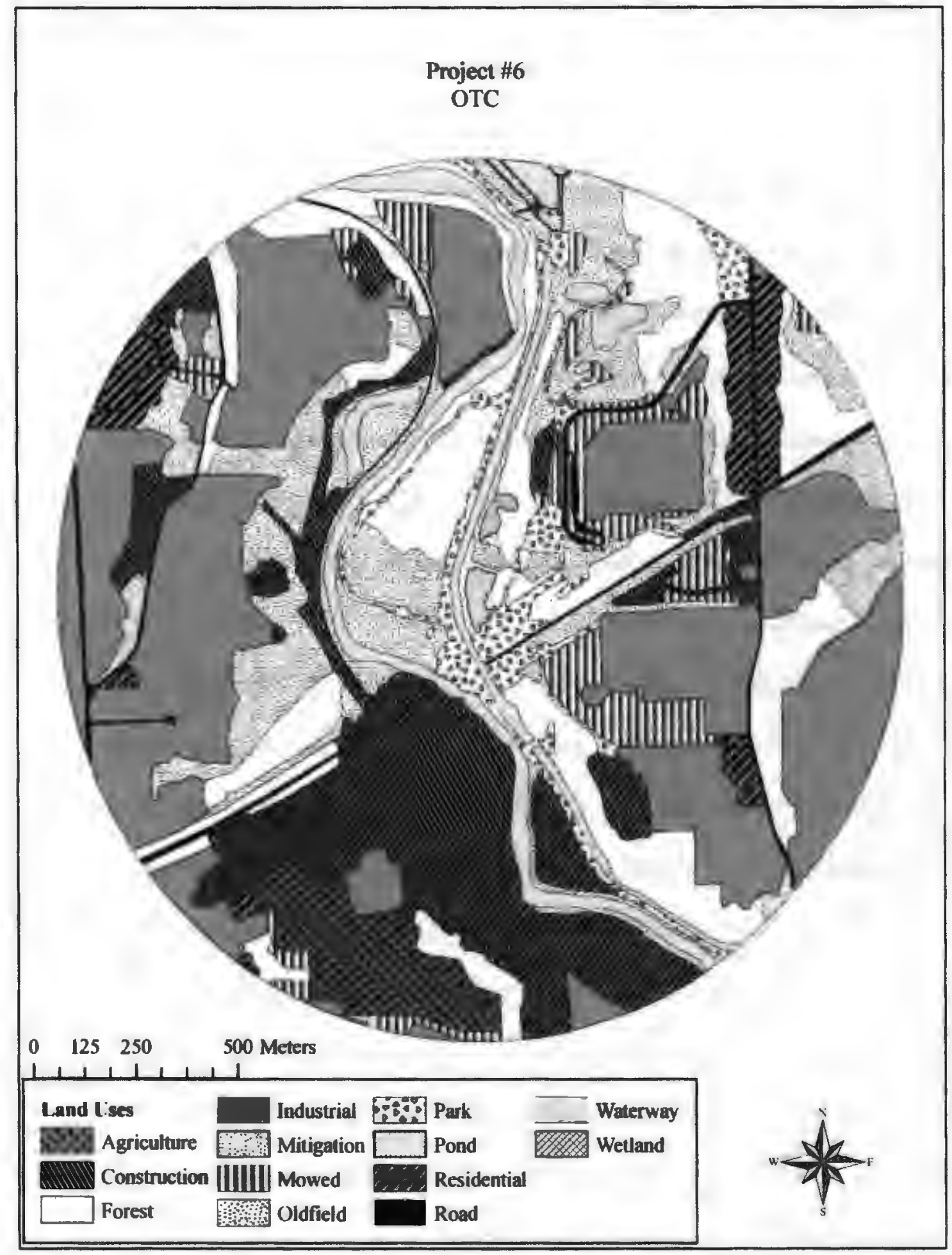

Figure $2.21000 \mathrm{~m}$ land use map for project \#6. Additional land use maps are located in Appendix G. 


\subsubsection{Amphibian Potential}

For amphibian habitat potential analysis (Question 3), $300 \mathrm{~m}$ landscapes were used for those mitigation sites $(n=9)$ where aerial photos were available. Information from the literature regarding landscape effects upon amphibian communities was used to select appropriate metrics for this portion of analysis. Amphibians have been shown to utilize a core habitat of 159 to $290 \mathrm{~m}$ from the edge of aquatic habitats (Semlitsch and Bodie 2003). A $300 \mathrm{~m}$ buffer from wetland edge was used in order to include the amount of area that would be required by amphibians. Amphibians have been shown to be positively correlated with area of forest, number of wetlands, and area of wetlands and negatively correlated with area of urban land use and road density (Findlay and Houlahan 1996, Knutson and others 1999, Houlahan and Findlay 2003, Porej and others 2004).

Amphibian habitat information extracted from the literature was used to create three amphibian potential scenarios (Table 2.1) which were applied to each mitigation site. Some of the landscape metrics that were used for amphibian potential analysis had a wide range of values and had to be standardized for comparison. For each scenario, landscape indices were standardized in two different ways. Set A was created by normalizing landscape indices using Minitab and assigning each site a value of 1 to 9. Values were transformed linearly by assigning the lowest value to 1 and the highest value to 9. Set B was created by plotting histograms for each index with five even break-points and assigning each site a value of 1 to 5 . Due to correlations between landscape indices (Appendix H), variables for amphibian potential analysis were reduced to percentage of landscape (forest, wetland, road, and urban land uses were used) and radius of gyration 
(forest and road land uses were used). The urban land use was created by adding the percentages for industrial and residential land uses.

\begin{tabular}{lll}
\hline Scenario 1 & Scenario 2 & Scenario 3 \\
\hline \%forest & \%forest & forest_gyrate \\
\%wetland & \%wetland & \%wetland \\
\%road & & road_gyrate \\
\%urban* & & \%urban* \\
\hline \%urban = \%residential + \%industrial
\end{tabular}

Table 2.1 Landscape metrics that were used for each amphibian potential scenario. Each scenario was standardized in two different ways, creating two datasets (Set A and Set B).

\subsection{Data Analysis and Interpretation}

Minitab statistical software Version 12.23 was used for all statistical analysis. Descriptive statistics, Pearson's correlations, normalization, histograms, two sample ttests, and paired t-tests were used. Pearson's correlations were used to select landscape indices for various portions of land use analysis. Correlations were also used to test whether variance in landscape area affected metric values. A Pearson's coefficient of $r>$ 0.700 or $r<-0.700$ was used to indicate metrics that were significantly correlated. Normalization and histograms were used to create standardized values for amphibian habitat potential analysis. Two sample t-tests were used to compare impacted and mitigation wetland characteristics when all projects were combined. Paired t-tests were used to compare impacted and mitigation characteristics on a per-project basis. A $95 \%$ confidence level was used to test significance. Several articles regarding the use of landscape metrics were consulted during the interpretation of FRAGSTATS output 
(Gustafson 1998, Moilanen and Nieminen 2002, Brooks 2003, Li and Wu 2004, Neel and others 2004) along with the FRAGSTATS users manual (McGarigal and others 2002).

\subsection{Wetland Restoration Potential}

To determine whether site selection was a factor in permit compliance success, locations of the mitigation wetlands were compared with data from a study of wetland restoration potential for the Cuyahoga River watershed (White and Fennessy 2005). White and Fennessy (2005) developed a GIS-based model using soils information, land use, topography, stream order, slope, and flow accumulation to create three different versions of wetland restoration potential for the Cuyahoga River watershed (Base Model, Alternative Weights Variation, and the Transmissivity Variation). The Transmissivity Variation (White and Fennessy 2005), which includes soil drainage potential within the topography factor, was used for this study. Each mitigation wetland project in the Cuyahoga River watershed $(n=11)$ was compared to the restoration potential map using ArcGIS and given a value of 0-100 as specified by White and Fennessy (2005). Mitigation wetlands were converted to raster form with a $3.048 \mathrm{~m}$ cell size. Each cell within the mitigation wetland was then assigned a value based upon the restoration potential map ( $25 \mathrm{~m}$ cell size). The mean of all cells for each mitigation project was used as the restoration potential value. Wetland restoration potential values were then compared with permit compliance. 


\section{CHAPTER 3}

\section{RESULTS}

\subsection{Permit Compliance}

Eight of the 23 projects purchased "wetland credits" at various pooled mitigation banks within the Ohio portion of the Lake Erie basin. None of these mitigation banks were located within the Cuyahoga River watershed. One project was mitigated at a bank owned by the applicant within the watershed. Two projects that impacted wetlands within the watershed were mitigated entirely through wetland preservation. Twelve projects relied upon independent creation or restoration efforts to mitigate for wetland losses (i.e., not at a bank). Of these 12 projects, 11 were located within the Cuyahoga River watershed. Nine of the 12 independent mitigation projects were constructed "onsite" while 3 sites were constructed at a location other than the impact site. A total of sixty-five wetlands were constructed as mitigation for 134 impacted wetlands. Because several wetlands can be impacted or constructed for each permit, the number of projects does not reflect the number of wetlands that were impacted.

For the 23 permits, 14.95 ha of wetland were lost, 27.78 ha of created or restored wetland were required, and 26.27 ha of mitigation wetlands were constructed. The 26.27 ha of mitigation wetlands assumes that requirements for the 8 mitigation bank projects 
were adequately met. The result is a net gain of 11.32 ha of wetlands at a replacement ratio of 1.76:1. A total of 5.24 ha (10 projects) of wetlands were purchased from a pooled mitigation bank and 0.77 ha (1 project) of wetlands were created within a private mitigation bank. Another 20.26 ha (12 projects) of wetlands were either created or restored by the applicant independently. An additional 2.11 ha of wetland enhancement and 21.30 ha of wetland preservation were proposed, although these areas were not evaluated for compliance.

Within the Cuyahoga River watershed, 14.58 ha of wetlands were lost and only 11.36 ha of wetlands were created of restored. The remaining 14.91 ha of wetland mitigation were exported from the watershed (Figure 3.1). Two independently constructed projects were responsible for 9.67 ha of exported wetland area and 5.24 ha of exported wetland area were the result of purchasing mitigation bank credits. The majority of the 12 independent projects $(n=8)$ did not achieve the required wetland area (Figure 3.2). 


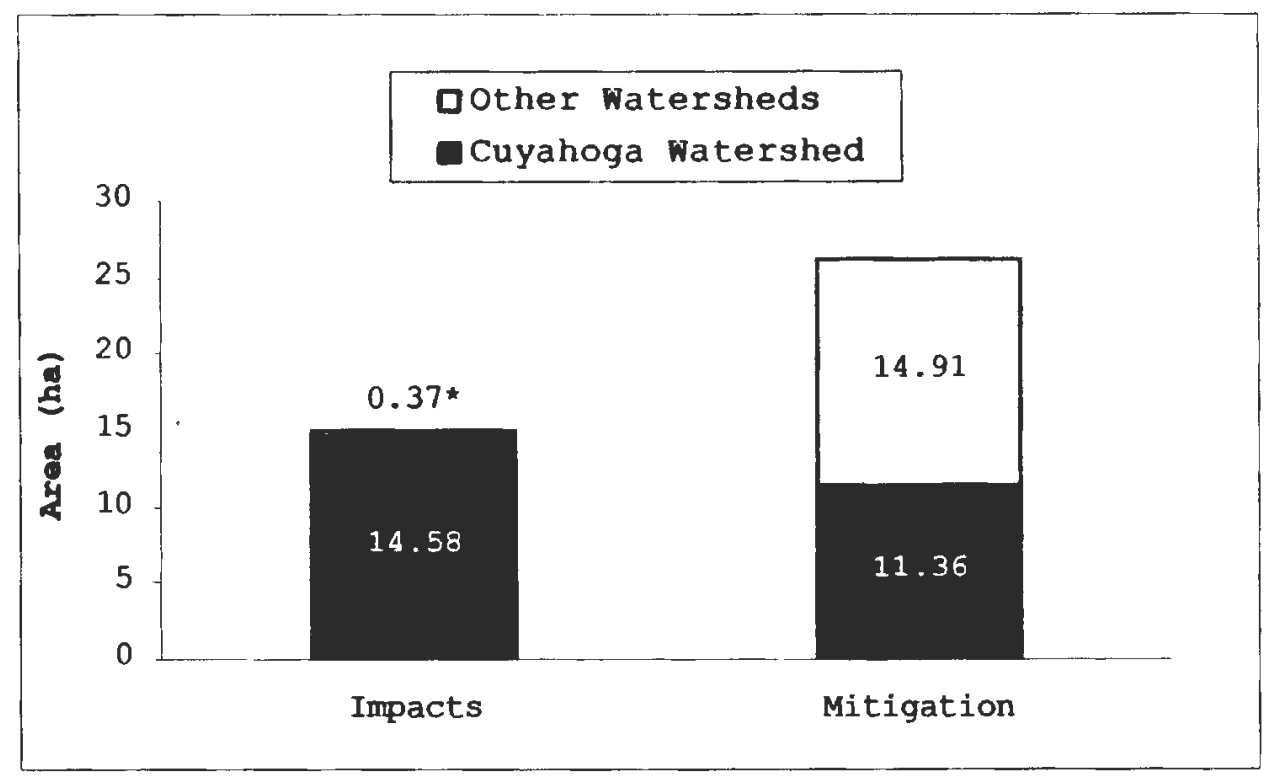

Figure 3.1 Area of wetlands that were mitigated in the Cuyahoga River watershed and wetland area that was exported from the watershed.

* A small portion of wetland associated with project \#12 was located outside of the Cuyahoga River watershed.

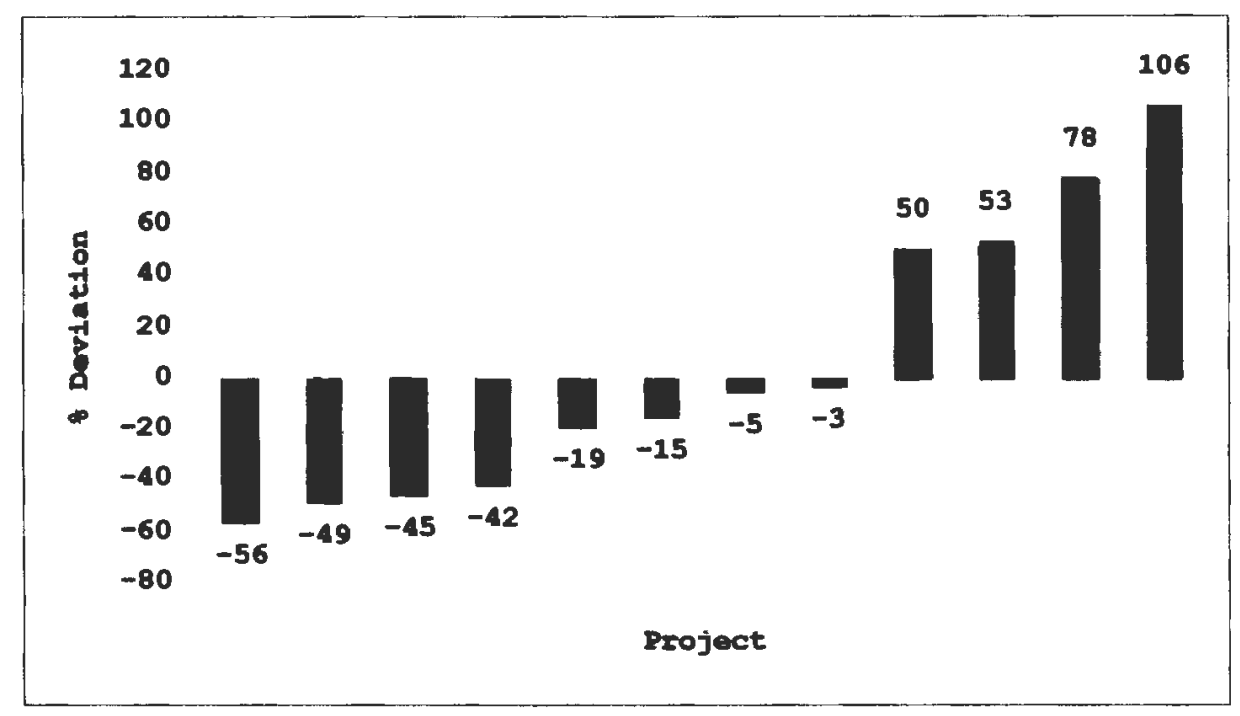

Figure 3.2 Percent deviation from the required mitigation wetland area. Projects with bars above the zero line constructed more wetland than necessary while those below the zero line failed to meet mitigation requirements. 


\subsection{Vegetation Types}

The vegetation types of wetlands that were impacted and constructed for the 12 independent projects were assessed (Figure 3.3). The majority of mitigation wetlands were comprised of open water/emergent vegetation ( $82.8 \%$ ) followed by scrub/shrub vegetation (14.7\%) and then forested vegetation (2.5\%). Based on information contained in permit files, impacted wetlands were also dominated by open water/emergent vegetation (42.5\%), followed by scrub/shrub (41.0\%) and then forested (16.5\%). Emergent wetlands were replaced at a ratio of 3.6:1 (constructed:impacted), scrub/shrub wetlands were replaced at a ratio of $0.65: 1$, and forested wetlands were replaced at a ratio of 0.28:1. If only the wetland impacts and mitigation in the Cuyahoga River watershed are considered, emergent wetlands were replaced at a ratio of 2.3:1 and scrub/shrub wetlands were replaced at a ratio of 0.03:1 (all forested wetland impacts were mitigated within the CRW). Vegetation types were analyzed on a per-project basis for wetland area for each vegetation type and also for presence/absence of vegetation types (Table 3.1). There was a significant increase in open water/emergent wetland area per project $(p=$ $0.014, \mathrm{df}=11, \mathrm{t}=-2.91)$ and a significant decrease in scrub/shrub wetland area $(\mathrm{p}=$ $0.019, \mathrm{df}=11, \mathrm{t}=2.75)$. The change in forested wetland area was not significant at a $95 \%$ confidence level $(p=0.088, d f=11, t=1.87)$. For the presence/absence analysis of vegetation types, forested vegetation was present more often in impacted wetlands than mitigation wetlands $(p=0.017, \mathrm{df}=11, t=2.80)$. Changes in the presence/absence of open water/emergent and scrub/shrub wetlands were not significant $(p=0.082, \mathrm{df}=11, t$ $=-1.91$ and $\mathrm{p}=0.191, \mathrm{df}=11, \mathrm{t}=1.39$, respectively). 


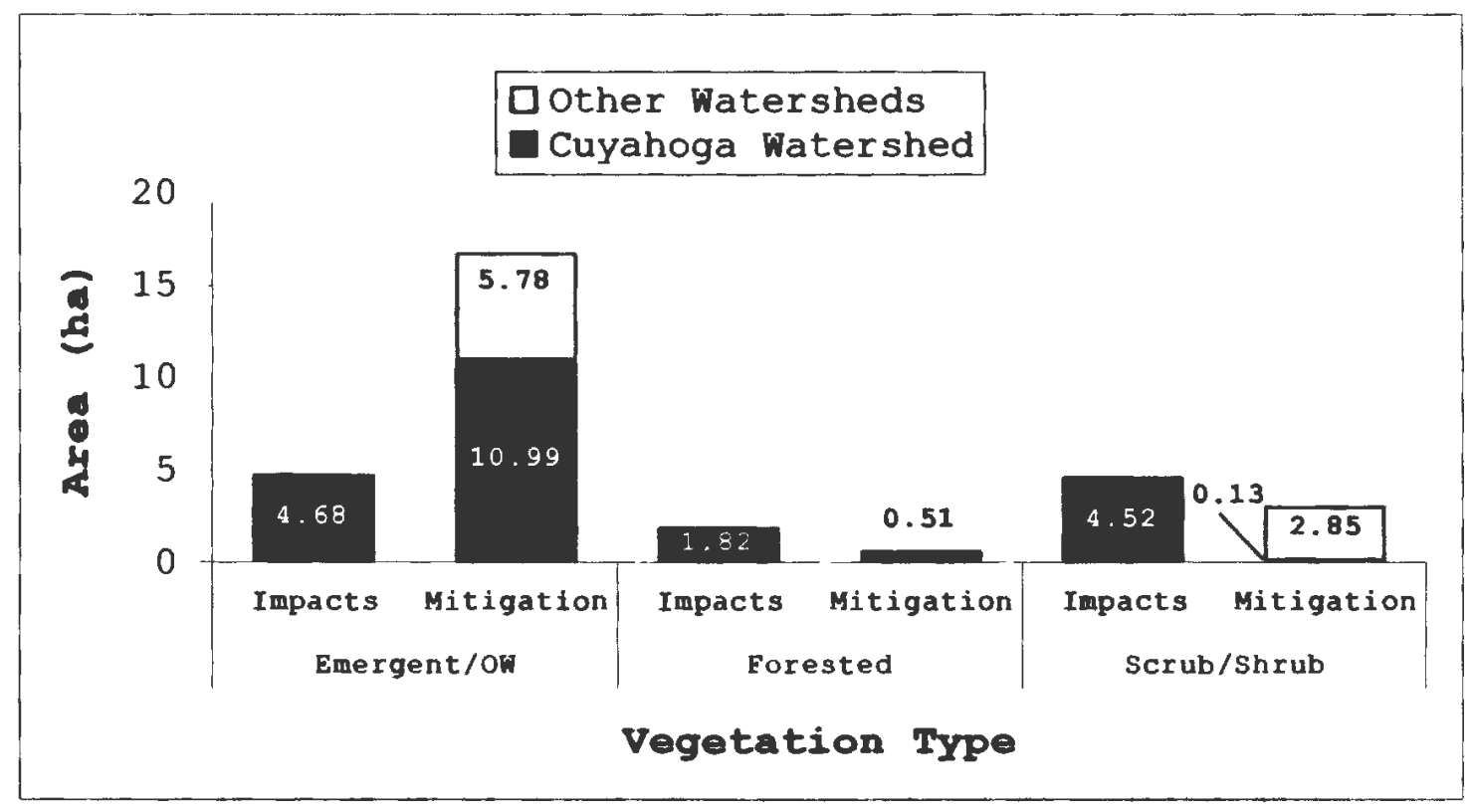

Figure 3.3 Vegetation types of impacted and mitigation wetlands. The wetland areas shown in white were exported to other watersheds.

\begin{tabular}{c|ccc|ccc}
\hline & & Impacts & & \multicolumn{2}{c}{ Mitigation } & \\
Project \# & Emergent/OW & Forested & Scrub/Shrub & Emergent/OW & Forested & Scrub/Shrub \\
\hline 1 & 1.125 & 0.313 & 0 & 1.372 & 0 & 0 \\
2 & 0 & 0.567 & 0 & 0.931 & 0.052 & 0.052 \\
3 & 0.291 & 0.101 & 0.170 & 1.424 & 0 & 0 \\
4 & 0 & 0 & 0.371 & 1.587 & 0 & 0.084 \\
5 & 1.576 & 0.310 & 3.096 & 5.780 & 0 & 2.847 \\
6 & 0.121 & 0.134 & 0.178 & 0.617 & 0.154 & 0 \\
7 & 0.295 & 0.202 & 0 & 2.440 & 0 & 0 \\
8 & 0.745 & 0.146 & 0 & 0.771 & 0 & 0 \\
9 & 0.069 & 0 & 0 & 0.108 & 0 & 0 \\
10 & 0.024 & 0 & 0 & 0.277 & 0 & 0 \\
11 & 0 & 0 & 0.231 & 0.243 & 0 & 0 \\
12 & 0.437 & 0.045 & 0.473 & 1.216 & 0.304 & 0 \\
\hline Totals & 4.684 & 1.818 & 4.519 & 16.766 & 0.510 & 2.982 \\
\hline
\end{tabular}

Table 3.1 Vegetation types by wetland area for impacted and mitigation wetlands. 


\subsection{Landscape Analyses}

\subsubsection{Generic Versus Actual Landscapes}

Generic landscapes were designed to be excessively simple in order to understand the behavior of landscape metrics. As a result, the metric values for generic landscapes were often quite different from those of actual landscapes. For example, the average percent of landscape for land use classes in generic landscapes was $21.8 \%$ and ranged from $0.09 \%$ to $73.8 \%$. The values for $300 \mathrm{~m}$ actual landscapes averaged $8.2 \%$ and ranged from $0.04 \%$ to $44.7 \%$. Interspersion and Juxtaposition Index (III) values for generic landscapes averaged 13.6 and ranged from 0 to 62.7 while II values for $300 \mathrm{~m}$ actual landscapes averaged 49.4 and ranged from 0 to 87.3. The $300 \mathrm{~m}$ actual landscapes also differed from $1000 \mathrm{~m}$ landscapes for some metrics. For example, due simply to the difference in landscape size, the $1000 \mathrm{~m}$ landscapes had more patches per landscape than did $300 \mathrm{~m}$ landscapes.

The landscape metrics for the actual landscapes in this study were also compared to those in other studies that have used FRAGSTATS to assess landscape composition and configuration. Other studies that used the same landscape metrics generally assessed large regions (macro-scale) while this study was conducted at a micro-scale. One study that assessed landscape structure in northwest China used IJ, among other landscape metrics ( $\mathrm{Li}$ and others 2001). IJI values for this region tended to be smaller $(\bar{x}=44.2)$ than in the smaller landscapes used for this study $(\bar{x}=49.4$ for $300 \mathrm{~m}$ landscapes; $\overline{\mathrm{x}}=$ 54.8 for $1000 \mathrm{~m}$ landscapes). Another study in northwest USA assessed disturbance in riparian areas using variable buffer sizes around streams and rivers (Staus and others 2002). Patch density was smaller $(\bar{x}=0.5$ patches $/ 100 \mathrm{ha})$ in these riparian areas than in 
the mitigation landscapes described herein $(\bar{x}=5.54$ patches $/ 100$ ha for $300 \mathrm{~m}$ landscapes; $\overline{\mathrm{x}}=3.07$ patches $/ 100$ ha for $1000 \mathrm{~m}$ landscapes).

\subsubsection{Wetland Spatial Configuration}

Overall, there was a decrease in the number of wetlands from 134 to 65 . The decrease in the number of wetlands within the CRW was from 134 to 50 . The decrease in number of wetlands on a per-project basis was not significant $(p=0.064, d f=22, t=$ 1.95); however, when one outlier was removed (project \#12) the decrease became significant $(p=0.004, d f=21, t=3.26)$. Project \#12 led to the creation of 25 of 65 mitigation wetlands. Mitigation wetlands $(n=65)$ for all projects were significantly larger than impacted wetlands $(n=134)(p=0.027, d f=74, t=2.26$; Figure 3.4). If two outliers were removed, the significance became greater $(p=0.002, \mathrm{df}=66, t=3.21)$. There was a decrease in the number of wetlands as a result of impacts and mitigation efforts for the majority of projects $(n=17)$. Wetland density (\# of wetlands/100 ha) was calculated for the 12 independent projects using FRAGSTATS. Although there was a slight decrease in wetland density, the difference was not significant $(p=0.723, \mathrm{df}=11, \mathrm{t}$ $=0.36$ ). 


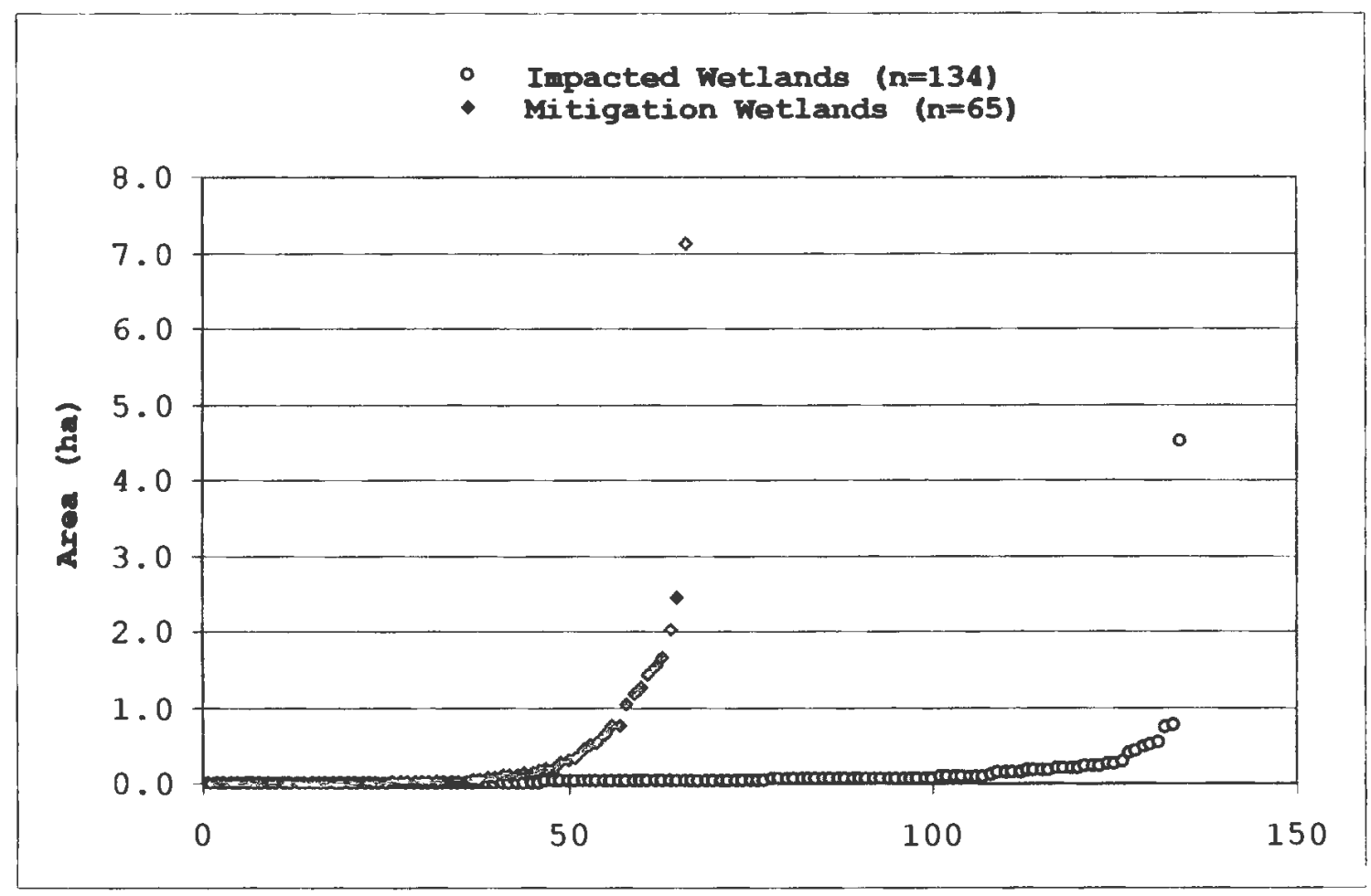

Figure 3.4 Size-ranked display of all impacted (open white) and mitigation (gray) wetlands. The $y$-axis shows the area of each wetland. The $x$-axis ranks each wetland by size showing 65 mitigation and 134 impacted wetlands.

\subsubsection{Composition of the Surrounding Landscape}

Land uses within $300 \mathrm{~m}$ and $1000 \mathrm{~m}$ landscapes were analyzed based upon the percent of landscape for each land use. The land uses that were located immediately adjacent to the mitigation wetland perimeters were also analyzed by measuring the length of edge that was shared by the mitigation wetlands and each land use. Forest was the dominant land use within $300 \mathrm{~m}$ and $1000 \mathrm{~m}$ landscapes surrounding the majority of the 9 mitigation projects that were analyzed (Table 3.2 ). The second and third most common land uses were residential and oldfield for the $300 \mathrm{~m}$ landscapes and residential and industrial for the $1000 \mathrm{~m}$ landscapes (Table 3.2). The most common land uses along 
mitigation wetland edges ( $n=8$ projects) were oldfield, mowed grass, and forest (Table 3.2)

\begin{tabular}{|c|c|c|c|c|c|c|c|c|c|c|c|c|c|}
\hline \multicolumn{14}{|c|}{$1000 \mathrm{~m}$ land uses } \\
\hline Proj \# & $\mathrm{Ag}$ & Const & For & Ind & Mit & Mow & Old & Park & Pond & Res & Road & Wway & Wet \\
\hline 1 & 0 & 4.0 & 44.8 & 1.7 & 0.4 & 6.2 & 14.3 & 0 & 0 & 15.0 & 4.3 & 4.2 & 5.0 \\
\hline 2 & 5.4 & 3.6 & 40.9 & 0 & 0.3 & 7.7 & 5.8 & 0 & 0.3 & 30.3 & 4.2 & 0 & 1.6 \\
\hline 3 & 0 & 6.4 & 19.9 & 23.1 & 0.4 & 7.9 & 12.6 & 0 & 0.3 & 15.2 & 14.1 & $\mathbf{0}$ & 0.1 \\
\hline 4 & 0 & 2.3 & 12.5 & 20.3 & 0.6 & 2.6 & 0.5 & 4.1 & 0 & 41.4 & 15.3 & 0.3 & $\mathbf{0}$ \\
\hline $5 a$ & 15.8 & 0.7 & 37.7 & 0 & 0.4 & 3.0 & 9.2 & 0 & 1.1 & 27.8 & 1.5 & 2.3 & 0.4 \\
\hline $5 b$ & 14.4 & 1.7 & 33.6 & 4.0 & 1.6 & 2.4 & 15.1 & 4.7 & 2.0 & 16.7 & 1.5 & 1.4 & 0.9 \\
\hline 6 & 3.4 & 15.2 & 16.8 & 32.7 & 0.2 & 4.8 & 15.0 & 3.9 & 1.0 & $\mathbf{0}$ & 2.9 & 3.9 & 0.1 \\
\hline 7 & 0.9 & 5.7 & 48.1 & 3.9 & 0.6 & 4.4 & 4.1 & 2.0 & 0.5 & 24.4 & 2.8 & 1.4 & 1.1 \\
\hline 8 & 0 & 5.1 & 40.7 & 12.6 & 0.2 & 11.0 & 11.2 & 0.7 & 0.9 & 10.6 & 5.3 & 1.2 & 0.5 \\
\hline \multicolumn{14}{|c|}{$300 \mathrm{~m}$ land uses } \\
\hline Proj \# & $\mathrm{Ag}$ & Const & For & Ind & Mit & Mow & Old & Park & Pond & Res & Road & Wway & Wet \\
\hline 1 & 0 & 1.9 & 36.1 & 0 & 2.7 & 9.3 & 31.9 & 0 & 0 & 1.6 & 5.8 & 0 & 10.8 \\
\hline 2 & 0 & 4.0 & 34.0 & 0 & 1.9 & 7.9 & 1.3 & 0 & 0.1 & 46.0 & 4.3 & ( & 0.3 \\
\hline 3 & 0 & 4.4 & 7.9 & 4.9 & 2.7 & 20.0 & 24.9 & 0 & 0 & $\mathbf{0}$ & 35.3 & 0 & 0 \\
\hline 4 & 0 & 13.7 & 35.7 & 3.2 & 4.0 & 5.3 & 0 & 0 & 0 & 25.7 & 11.7 & 0.6 & 0 \\
\hline $5 a$ & 26.7 & 0 & 45.8 & 0 & 2.4 & 0.5 & 2.8 & 0 & 0.1 & 12.5 & 1.2 & 6.0 & 2.0 \\
\hline $5 b$ & 9.4 & 2.0 & 11.5 & 5.4 & 10.2 & 1.9 & 29.2 & 5.7 & 6.0 & 15.5 & 1.1 & 0 & 2.1 \\
\hline 6 & 0 & 9.3 & 26.3 & 1.8 & 1.9 & 6.7 & 23.4 & 19.0 & 0 & $\mathbf{0}$ & 2.9 & 7.6 & 1.2 \\
\hline 7 & 0 & 2.0 & 59.0 & 0 & 4.4 & 2.5 & 12.2 & 4.4 & 0.4 & 11.0 & 2.2 & 0.1 & 1.8 \\
\hline 8 & 0 & 12.0 & 43.3 & 14.5 & 1.7 & 8.6 & 9.2 & 0 & 0.1 & 5.5 & 2.1 & 3.2 & 0 \\
\hline
\end{tabular}

Land uses along mitigation wetland edges

\begin{tabular}{cccccccccccccc} 
Proj \# & Ag & Const & For & Ind & Mit & Mow & Old & Park & Pond & Res & Road & Wway & Wet \\
\hline 1 & 0 & 0 & 8 & 0 & 0 & 16 & $\mathbf{4 1}$ & 0 & 0 & 0 & 0 & 0 & 34
\end{tabular}

$\begin{array}{llllllllllllll}2 & 0 & 0 & 23 & 0 & 0 & 73 & 0 & 0 & 0 & 4 & 0 & 0 & 0\end{array}$

$\begin{array}{llllllllllllll}3 & 0 & 0 & 0 & 0 & 0 & 34 & 66 & 0 & 0 & 0 & 0 & 0 & 0\end{array}$

$\begin{array}{llllllllllllll}4 & 0 & 33 & 61 & 0 & 0 & 5 & 0 & 0 & 0 & 0 & 0 & 0 & 0\end{array}$

$\begin{array}{llllllllllllll}5 & 57 & 0 & 9 & 0 & 0 & 0 & 26 & 0 & 0 & 0 & 0 & 0 & 8\end{array}$

$\begin{array}{llllllllllllll}6 & 0 & 0 & 82 & 0 & 0 & 0 & 0 & 18 & 0 & 0 & 0 & 0 & 0\end{array}$

$\begin{array}{llllllllllllll}7 & 0 & 2 & 33 & 0 & 0 & 0 & 61 & 0 & 0 & 0 & 4 & 0 & 0\end{array}$

$\begin{array}{cccccccccccc}8 & 0 & 0 & 0 & 0 & 0 & 100 & 0 & 0 & 0 & 0 & 0 \\ \mathrm{Ag}= & \text { Agriculture, } & \text { Const }=\text { Construction, For }=\text { Forest, Ind }=\text { Industrial, } & \text { Mit }=\text { Mitigation wetland }\end{array}$ Mow $=$ Mowed grass, Old $=$ Oldfield, Res $=$ Residential, Wway $=$ Waterway, Wet $=$ Wetland

Table 3.2 Land uses percentages for each project. Bold numbers indicate the dominant land use for each project. 
Within $300 \mathrm{~m}$ landscapes, natural land uses ranged from $33 \%$ to $75 \%$ and human land uses ranged from $18 \%$ to $65 \%$ of total landscape area (Figure 3.5 ). At the $300 \mathrm{~m}$ level, 3 projects were dominated by human land uses and 5 were dominated by natural land uses. Natural land uses within $1000 \mathrm{~m}$ landscapes ranged from $17 \%$ to $59 \%$ of total landscape area and human land uses ranged from $31 \%$ to $82 \%$ (Figure 3.6). At the 1000 $\mathrm{m}$ level, 5 projects were dominated by human land uses and 3 were dominated by natural land uses. Within $300 \mathrm{~m}$ landscapes, projects \#2 and \#3 had the highest amount of human land use and lowest natural land use while projects \#1, \#6, and \#7 had the lowest human land use and highest natural land use. At the $1000 \mathrm{~m}$ level, projects \#3 and \#4 had the highest human land use and lowest natural land use while projects \#1, \#5b, and \#7 had the lowest human land use and highest natural land use.

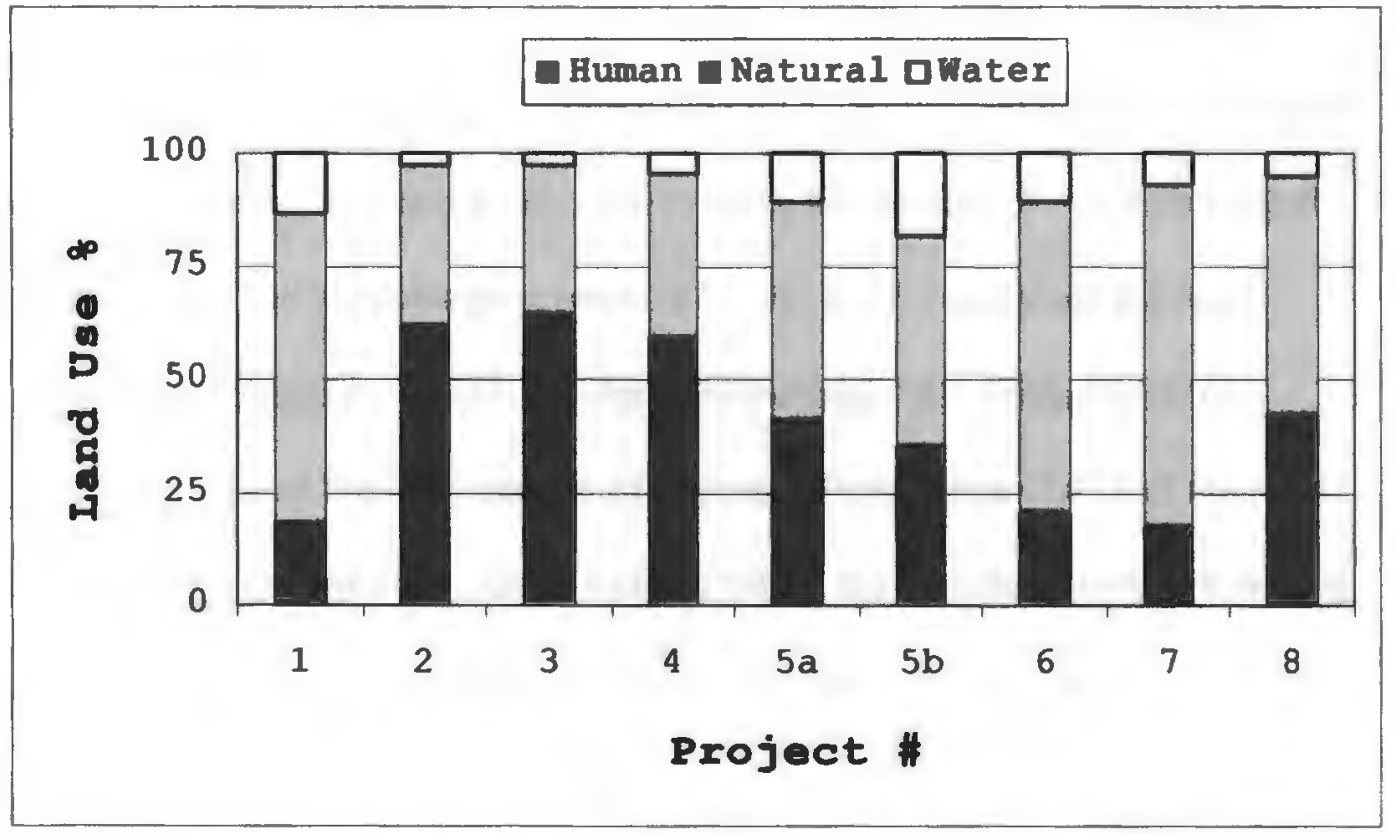

Figure 3.5 Combined land use percentages for $300 \mathrm{~m}$ landscapes. 


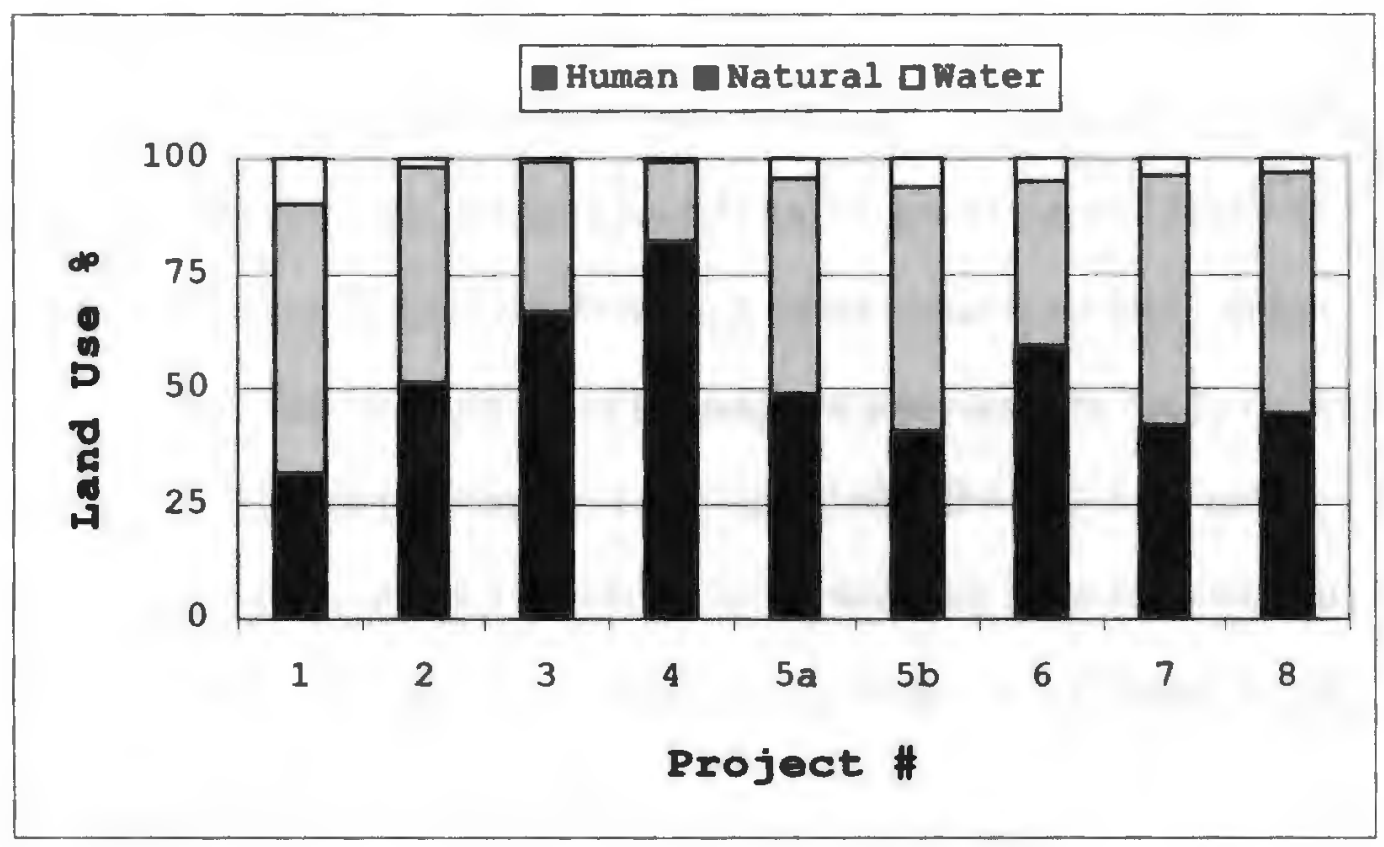

Figure 3.6 Combined land use percentages for $1000 \mathrm{~m}$ landscapes.

The number of wetlands located in $300 \mathrm{~m}$ and $1000 \mathrm{~m}$ landscapes (excluding mitigation wetlands) was calculated using FRAGSTATS. At the $300 \mathrm{~m}$ level, the number of wetlands ranged from 0 to 8 and at the $1000 \mathrm{~m}$ level, the number of wetlands ranged from 0 to 19. Within $300 \mathrm{~m}$ landscapes, projects \#3, \#4, and \#8 contained the least amount of wetlands (0) and project \#1 had the most wetlands (8). Within $1000 \mathrm{~m}$ landscapes, project \#4 had the least amount of wetlands (0) and project \#7 had the most wetlands (19). When mitigation wetlands were included, the number of wetlands ranged from 1 to 10 at the $300 \mathrm{~m}$ level and from 1 to 20 at the $1000 \mathrm{~m}$ level. 


\subsubsection{Amphibian Potential}

Although some variation was present, projects \#1 and \#7 had the highest potential for amphibian communities while projects \#2 and \#3 had the lowest potential (Table 3.3). Most of the variation was associated with Scenario 3, which included radius of gyration and proximity index in addition to percent of landscape for land uses. The results for Set A were significantly different for Scenarios 1 and $2(p<0.001, \mathrm{df}=8, t=6.03)$ and for Scenarios 1 and $3(p=0.011, d f=8, t=3.29)$ but not for Scenarios 2 and $3(p=0.09, d f$ $=8, t=-1.93$ ). The results for Set B were significantly different only for Scenarios 1 and $2(p=0.001, d f=8, t=5.55)$.

\begin{tabular}{c|ccccc}
\hline \multicolumn{1}{l}{$\begin{array}{c}\text { Set A } \\
\text { Project \# }\end{array}$} & Scenario 1 & Scenario 2 & Scenario 3 & Average & Std Dev \\
\hline 1 & 7.8 & 7.2 & 5.3 & 6.8 & 1.3 \\
2 & 3.9 & 3.2 & 3.0 & 3.4 & 0.5 \\
3 & 2.9 & 1.0 & 2.3 & 2.0 & 0.9 \\
4 & 4.2 & 3.2 & 3.8 & 3.7 & 0.5 \\
5a & 6.4 & 4.7 & 5.5 & 5.5 & 0.8 \\
5 b & 4.7 & 2.0 & 3.4 & 3.4 & 1.3 \\
6 & 5.8 & 2.9 & 4.9 & 4.5 & 1.5 \\
7 & 6.8 & 5.7 & 6.5 & 6.3 & 0.6 \\
8 & 5.5 & 3.8 & 5.8 & 5.0 & 1.1 \\
\hline Set B & & & & & \\
Project \# & Scenario 1 & Scenario 2 & Scenario 3 & Average & Std Dev \\
\hline 1 & 4.3 & 4.0 & 3.5 & 3.9 & 0.4 \\
2 & 2.5 & 2.0 & 1.3 & 1.9 & 0.6 \\
3 & 2.0 & 1.0 & 2.8 & 1.9 & 0.9 \\
4 & 2.8 & 2.0 & 3.0 & 2.6 & 0.5 \\
5a & 3.8 & 3.0 & 3.3 & 3.3 & 0.4 \\
5 b & 2.8 & 1.5 & 2.5 & 2.3 & 0.7 \\
6 & 3.3 & 1.5 & 3.3 & 2.7 & 1.0 \\
7 & 4.0 & 3.5 & 2.8 & 3.4 & 0.6 \\
8 & 3.3 & 2.5 & 2.0 & 2.6 & 0.6 \\
\hline
\end{tabular}

Table 3.3 Results for amphibian habitat potential analysis. Shaded cells indicate the two highest values for each scenario and the average. Bolded text indicates the two lowest values for each scenario and the average. 


\subsection{Landscape Area Variability}

The area of landscapes was variable (Appendix F) because they were created using a buffer distance $(300 \mathrm{~m}$ and $1000 \mathrm{~m})$ from the edge of mitigation wetlands which were of different sizes and shapes. This variability has the potential to affect landscape metrics calculated by FRAGSTATS (McGarigal and others 2002). Correlations were calculated for wetland spatial configuration metrics, land use percentages, and amphibian potential metrics to determine if landscape area affected results. According to Pearson's correlations, construction percent of landscape and residential percent of landscape for $1000 \mathrm{~m}$ landscapes were the only metrics that were affected by variability in landscape area (Appendix I). The only analysis that would be affected by these metrics is the general description of landscape setting (Section 3.3.2). Although construction percent of landscape did not comprise a large portion of landscapes $(\bar{x}=5.0 \%)$, residential percent of landscape was responsible for a substantial amount of landscape area $(\bar{x}=22.7 \%)$. Since these metrics were combined with other land uses, the effects of landscape area should be diminished. Nonetheless, interpretation of the results in Section 3.3 should be done with the effects of landscape area in mind.

\subsection{Restoration Potential}

The average restoration potential (as calculated following White \& Fennessy (2005)) for the 11 mitigation sites in the Cuyahoga River watershed ranged from 0 to 44.6. The four projects that constructed at least the required wetland area had four of the five lowest restoration potential values. The relationship between restoration potential and compliance was not significant $(p=.735, \mathrm{df}=10, t=0.35)$. 


\section{CHAPTER 4}

\section{DISCUSSION}

\subsection{Permit Compliance}

Recent studies of wetland permit compliance have re-enforced uncertainties about our abilities to create wetland ecosystems. Some reports have found most permit-holders to be in compliance with permit conditions (e.g., Cole and Shafer 2002, Minkin and Ladd 2003). Others have found that the majority of permit-holders were unable to successfully meet permit requirements (e.g., Johnson and others 2000, Brown and Veneman 2001). A net-gain of wetland area has been reported by some studies (e.g., Johnson and others 2000, Breaux and others 2005) and a net-loss has been reported by others (e.g., Sudol and Ambrose 2002, Morgan and Roberts 2003). The majority of the CRW projects that were evaluated did not meet wetland area requirements. Although there has been a net gain in wetland area overall as a result of these projects, the CRW experienced a net loss of wetland area. Only $77.9 \%$ of the area of wetlands impacted is now present as mitigation wetlands within the watershed. These results highlight one of the problems associated with "off-site" mitigation

Nine of the 21 projects that created or restored wetlands for mitigation did so entirely within a watershed other than the CRW. Eight of these projects mitigated for impacts by purchasing wetland credits at a mitigation bank. Mitigation banks have been 
designed to allow permit-holders who are impacting small areas of wetland to mitigate for impacts by purchasing "wetland credits" instead of creating or restoring wetlands "onsite" (Reppert 1992). The question then, is to what extent we should allow wetland functions to be trans-located geographically. Within Ohio, permit-holders are restricted to using mitigation banks that are located within the United States Army Corps of Engineers (USACOE) district (i.e., Buffalo or Huntington) but are permitted to mitigate in different watersheds for lower quality wetlands (Ohio Administrative Code 3745-154). Such authorization of wetland exportation should consider the function and context of the impacted wetlands and the mitigation bank. If the impacted wetlands are functionally inferior and located within intensive urban settings, then their replacement with a higher quality mitigation bank may be justified. However, a portion of the lower Cuyahoga River has been declared by the Unites States EPA as an area of concern (USEPA 2003). Areas of concern are designed to focus efforts to clean up the most polluted areas of the Great Lakes region. The exportation of wetland mitigation from the CRW has resulted in a net loss of wetland functions (Faulkner 2004) which potentially could have had a positive impact upon the pollution problem in the Cuyahoga River.

\subsection{Wetland Structure}

Impacted and mitigation wetlands were both dominated by emergent vegetation and open water. However, the percentage of wetlands that were emergent/open water nearly doubled as a result of mitigation efforts. The amount of forested and scrub/shrub wetlands both decreased in area as a result of mitigation policy. A shift from forested and scrub/shrub wetlands to emergent/open water dominated systems has been reported 
by many wetland mitigation studies (e.g., Brown and Veneman 2001, Cole and Shafer 2002, Minkin and Ladd 2003). It has been hypothesized that this shift is occurring because emergent/open water wetlands are easier to construct than forested or scrub/shrub wetlands (Cole and Shafer 2002, Porej 2003). Construction of a deep open water/emergent depression also seems to be the most reliable way (Porej 2003) to meet the hydrology, soil, and vegetation requirements set forth by the USACOE wetland definition (USACOE 1987). Such a shift in wetland types is likely to cause a regional shift in biodiversity (Gwin and others 1999) and will probably also indicate a shift in wetland function (Minkin and Ladd 2003).

In addition to changes in wetland type, there has also been a change in wetland spatial structure in the CRW. A total of 134 wetlands were impacted and only 50 replacement wetlands were constructed in the CRW. The average size of impacted wetlands was 0.11 ha and the average size of CRW replacement wetlands was 0.23 ha. Essentially, the landscape is experiencing a consolidation of many small wetlands into fewer, larger ecosystems. Amezaga and others (2002) stated that the maintenance of a rich distribution of wetlands in the landscape is just as important as maintaining high quality wetlands. The loss of many small wetlands has obvious consequences upon landscape heterogeneity and metapopulation dynamics (Semlitsch and Bodie 1998). Although the impact of such spatial re-configuration upon many ecosystem and landscape functions is still unknown, research has suggested that effects upon organism persistence and nutrient distribution are likely to occur (Kelly 2001 and references therein). 


\subsection{Composition of the Surrounding Landscape}

There was considerable variation in land uses for the nine mitigation projects that were studied as part of the investigation of general landscape composition. Three of the projects were situated within particularly harsh areas, with urban land uses comprising more than $50 \%$ of the landscape (projects $\# 2,3$, and 4). Mitigation wetlands associated with project \#2 were predominantly open water wetlands located within a suburban housing development. Project \#3 was located immediately adjacent to a highway intersection for which wetland impacts associated with this project were necessary. The mitigation wetland associated with project \#4 was a fringe wetland surrounding a stormwater retention basin within a very urban area. In contrast, the two projects that were located in the most natural landscapes (projects \#1 and 5b) were both located within parks. It appears from these results that mitigation wetlands are being constructed in a wide variety of landscape settings. This will allow these wetlands to serve varied functions to society. For example, the wetlands located in park settings will very likely provide wildlife and recreational functions to the surrounding community. The highway wetland will hopefully provide the same filtration for water leaving the interstate that the impacted wetlands did. One concern is that the wetlands located in highly humanimpacted landscapes could become overwhelmed and some functions could be sacrificed (Mitsch and Gosselink 2000). As expected, some of the projects that were located within urban areas also had the lowest number of wetlands present in the surrounding landscape. Three projects (\#3, 4, and 8) did not have any wetlands within $300 \mathrm{~m}$ that were visible in aerial photographs. There were no visible wetlands within the $1000 \mathrm{~m}$ landscape for project \#4. In fact, the only surface water present in the $1000 \mathrm{~m}$ landscape for this project 
was the urban stream and storm-water retention basin within which the mitigation wetlands were constructed. This disconnectedness from other wetlands and water bodies in the landscape can be expected to have effects upon the biodiversity and maintenance of species populations within wetlands (Amezaga and others 2002). The consolidation of impacted wetlands into fewer, larger replacement wetlands has already been discussed. The same issues also need to be scaled to the landscape level. The presence of wetlands and other water bodies in the surrounding landscape needs to be taken into consideration during mitigation planning in order to maintain landscape heterogeneity and species populations.

\subsection{Amphibian Potential}

The two projects with the lowest amphibian potential (projects \#2 and 3) were located within landscapes that were dominated by residential areas and roads, respectively. In contrast, the two projects with the highest amphibian potential (projects \#1 and 7) were both located in landscapes dominated by forest. Even with the documentation of landscape components that are positively (forest, wetlands) and negatively (urban, roads) correlated with amphibians, there are no definite threshold levels (Knutson and others 1999, Houlahan and Findlay 2003, Porej et al. 2004). As a result, it is not possible to specify which of these projects would be able to support certain amphibian species. Additionally, there are other compounding factors, including wetland characteristics that have been shown to be correlated with amphibian populations (e.g., hydroperiod, fish presence; Porej 2004). Consequently, the analysis provided here 
is only useful for ranking wetlands with regards to the potential to provide amphibian habitat.

None of the permits listed amphibian habitat as a goal for the mitigation wetlands. In fact, none of the permits listed any functional requirements at all. The amphibian potential analysis was not designed to determine whether or not projects were successful. Instead, the purpose was to provide a method for considering landscape setting in the planning stages of wetland mitigation. If validated, the amphibian scenarios used here could be used as a tool for locating wetlands that would have the potential to provide amphibian habitat. Such a method is possible for amphibians because there is a wealth of information regarding the terrestrial requirements for such species as mole salamanders and wood frogs. Similar tools could be designed for other wetland functions where land use effects are well understood.

\subsection{Restoration Potential}

Comparing the wetland restoration potential data by White and Fennessy (2005) with permit compliance did not reveal any significant relationships. The lack of correlation is not surprising because site selection is one of many factors that must be considered when creating and restoring wetlands. The inability of some projects to achieve the required wetland area could have been a result of a variety of factors, including poor site engineering or planning, instead of poor site selection. 


\section{CHAPTER 5}

\section{CONCLUSION}

Although the permits studied resulted in an overall net gain of wetlands, the Cuyahoga River watershed has experienced a net loss of wetland area. The functions provided by the majority of mitigation wetlands have been exported to other watersheds in the state. This exportation has occurred as a result of off-site mitigation, including the purchasing of wetland credits from mitigation banks. The net loss of wetland area from the watershed is also partly due to the inability of permit-holders to construct the required amount of mitigation wetland area. The majority of independent mitigation projects (i.e., not at a mitigation bank) did not construct enough wetland area to fulfill permit requirements. More rigorous follow-up and enforcement is necessary to ensure that wetland impacts and permit requirements are being adequately addressed. Also, permitholders and regulatory agencies need to consider the locations of wetland impacts and mitigation instead of relying solely upon a site-by-site review.

The Cuyahoga River watershed has experienced a shift in wetland structural characteristics as a result of wetland mitigation efforts. There is a consolidation of many small wetlands into fewer, larger systems. This shift could indicate an increase in the distance between wetlands and a loss of upland-wetland complexes. Many of the forested and 
scrub/shrub wetlands that are destroyed are being replaced with emergent vegetation and open water wetlands. Although these structural characteristics are not measures of wetland function, they could be indicators that some functional changes are occurring both within wetlands and across the landscape. Incorporating landscape setting into the permitting process would allow for a more comprehensive understanding of any changes that are resulting from mitigation efforts. Additional research is necessary to understand how landscape structure affects the functioning of wetlands themselves and their ability to improve downstream water resources. 


\section{LIST OF REFERENCES}

Allen, A. O., and J. J. Feddema. 1996. Wetland loss and substitution by the Section 404 permit program in Southern California, USA. Environmental Management 20:263-274.

Ambrose, R. F. 2000. Wetland mitigation in the United States: assessing the success of mitigation policies. Wetlands (Australia) 19:1-27.

Amezaga, J. M., L. Santamaria, and A. J. Green. 2002. Biotic wetland connectivity supporting a new approach for wetland policy. Acta Oecologica 23:213-222.

Bedford, B. L. 1996. The need to define hydrologic equivalence at the landscape scale for freshwater wetland mitigation. Ecological Applications 6:57-68.

Bedford, B. L., and E. M. Preston. 1988. Developing the scientific basis for assessing cumulative effects of wetland loss and degradation on landscape functions: status, perspectives, and prospects. Environmental Management 12:751-771.

Breaux, A., S. Cochrane, J. Evens, M. Martindale, B. Pavlik, L. Suer, and D. Benner. 2005. Wetland ecological and compliance assessments in the San Francisco Bay Region, California, USA. Journal of Environmental Management 74:217-237.

Brinson, M. M. 1993. A hydrogeomorphic classification for wetlands. Technical report WRP-DE-4. U.S. Army Corps of Engineer Waterways Experiment Station, Vicksburg, Mississippi, 103 pp.

Brooks, C. P. 2003. A scalar analysis of landscape connectivity. Oikos 102:433-439.

Brown, S. C., and P. L. M. Veneman. 2001. Effectiveness of compensatory wetland mitigation in Massachusetts, USA. Wetlands 21:508-518.

Colburn, E. A. 2004. Vernal pools: natural history and conservation. The McDonald \& Woodward Publishing Company, Blacksburg, Virginia, 426 pp.

Cole, A. C., and D. Shafer. 2002. Section 404 wetland mitigation and permit success criteria in Pennsylvania, USA, 1986-1999. Environmental Management 30:508-515. 
Croonquist, M. J., and R. P. Brooks. 1993. Effects of habitat disturbances on bird communities in riparian corridors. Journal of Soil and Water Conservation 48:65-70.

Ehrenfeld, J. G., and J. P. Schneider. 1991. Chamaecyparis thyoides wetlands and suburbanization: effects on hydrology, water quality and plant community composition. Journal of Applied Ecology 28:467-490.

Environmental Law Institute (ELI). 2004. Pages 80-88 in Proceedings of the national symposium on compensatory mitigation and the watershed approach, 19-21 May 2004. Washington, D.C.

Faulkner, S. 2004. Urbanization impacts on the structure and function of forested wetlands. Urban Ecosystems 7:89-106.

Findlay, C. S., and J. Houlahan. 1996. Anthropogenic correlates of species richness in Southeastern Ontario wetlands. Conservation Biology 11:1000-1009.

Gustafson, E. J. 1997. Quantifying landscape spatial pattern: what is the state of the art? Ecosystems 1:143-156.

Gustafson, E. J., and G. R. Parker. Relationships between landcover proportion and indices of landscape spatial pattern. Landscape Ecology 7:101-110.

Gwin, S. E., M. E. Kentula, and P. W. Shaffer. 1999. Evaluating the effects of wetland regulation through hydrogeomorphic classification and landscape profiles. Wetlands 19:477-489.

Hecnar, S. J. 2004. Great Lakes wetlands as amphibian habitats: a review. Aquatic Ecosystem Health and Management 7:289-304.

Houlahan, J. E., and C. S. Findlay. 2003. The effects of adjacent land use on wetland amphibian species richness and community composition. Canadian Journal of Fisheries and Aquatic Sciences 60:1078-1094.

Houlahan, J. E., and C. S. Findlay. Estimating the critical distance at which adjacent land-use degrades wetland water and sediment quality. Landscape Ecology 19:677-690.

Johnson, P. A., D. L. Mock, A. McMillan, L. Driscoll, and T. Hruby. 2002. Washington State wetland mitigation evaluation study: phase 2: evaluating success. Publication No. 02-06-009. Washington State Department of Ecology, Olympia, Washington, 159 pp.

Johnson, P. A., D. L. Mock, E. J. Teachout, and A. McMillan. 2000. Washington State wetland mitigation evaluation study: phase 1: compliance. Publication No. 00-06-016. Washington State Department of Ecology, Olympia, Washington, 94 pp. 
Kelly, N. M. 2001. Changes to the landscape pattern of coastal North Carolina wetlands under the Clean Water Act, 1984-1992. Landscape Ecology 16:3-15.

Kentula, M. E. 2000. Perspectives on setting success criteria for wetland restoration. Ecological Engineering 15:199-209.

Kettlewell, C. I. 2005. An inventory of Ohio wetland compensatory mitigation: part 2. Final report to U.S. EPA Grant No. CD97576201-0. Ohio Environmental Protection Agency, Division of Surface Water, Wetland Ecology Group, Columbus, Ohio, 25 pp.

Knutson, M. G., J. R. Sauer, D. A. Olsen, M. J. Mossman, L. M. Hemesath, and M. J. Lannoo.1999. Effects of landscape composition and wetland fragmentation on frog and toad abundance and species richness in lowa and Wisconsin, USA. Conservation Biology 13:1437-1446.

Li, H., and J. Wu. 2004. Use and misuse of landscape indices. Landscape Ecology 19:389-399.

Li, X., L. Lu, G. Cheng, and H. Xiro. 2001. Quantifying landscape structure of the Heihe River Basin, north-west China using FRAGSTATS. Journal of Arid Environments 48:521-535.

McGarigal, K., S. A. Cushman, M. C. Neel, and E. Ene. 2002. Fragstats: spatial pattern analysis program for categorical maps. Available: www.umass.edu/landeco/research/ fragstats/fragstats.html.

Minkin, P., and R. Ladd. 2003. Success of corps-required wetland mitigation in New England. U.S. Army Corps of Engineers, New England District, Waltham, Massachusetts, $26 \mathrm{pp}$.

Mitsch, W. J., and J. G. Gosselink. 2000. The value of wetlands: importance of scale and landscape setting. Ecological Economics 35:25-33.

Mitsch, W. J., and R. F. Wilson. 1996. Improving the success of wetland creation and restoration with know-how, time, and self-design. Ecological Applications 6:77-83.

Moilanen, A., and M. Nieminen. 2002. Simple connectivity measures in spatial ecology. Ecology 83:1131-1145.

Molles Jr., Manuel C. 2002. Ecology: concepts and applications, second edition. McGraw-Hill, New York, New York, 586 pp.

Morgan, K. L., and T. H. Roberts. 2003. Characterization of wetland mitigation projects in Tennessee, USA. Wetlands 23:65-69. 
Neel, M. C., K. McGarigal, and S. A. Cushman. 2004. Behavior of class-level landscape metrics across gradients of class aggregation and area. Landscape Ecology 19:435-455.

Porej, D. 2003. An inventory of Ohio wetland compensatory mitigation. Final report to U.S. EPA Grant No. CD97576201-0. Ohio Environmental Protection Agency, Division of Surface Water, Wetland Ecology Group, Columbus, Ohio, 25 pp.

Porej, D. 2004. Faunal aspects of wetland creation and restoration. Ph.D. Dissertation, The Ohio State University, Columbus, Ohio, 117 pp.

Porej, D., M. Micacchion, and T. E. Hetherington. 2004. Core terrestrial habitat for conservation of local populations of salamanders and wood frogs in agricultural landscapes. Biological Conservation 120:399-409.

Race, M. S., and M. S. Fonseca. 1996. Fixing compensatory mitigation: what will it take? Ecological Applications 6:94-101.

Reppert, R. 1992. National wetland mitigation banking study: wetlands mitigation banking concepts. IWR Report 92-WMB-1. U.S. Army Corps of Engineers, Water Resources Support Center, Institute for Water Resources, Alexandria, Virginia, 25 pp.

Robb, J. T. 2000. Indiana wetland compensatory mitigation inventory. Final report to U.S. EPA Grant No. CD985482-010-0. Indiana Department of Environmental Management, Indianapolis, Indiana, 22 pp.

Semlitsch, D. R., and J. R. Bodie. 2003. Biological criteria for buffer zones around wetlands and riparian habitats for amphibians and reptiles. Conservation Biology. 17:1219-1228.

Semlitsch, R. D., and J. R. Bodie. 1998. Are small, isolated wetlands expendable? Conservation Biology 12:1129-1133.

Simenstad, C. A., and R. M. Thom. 1996. Functional equivalency trajectories of the restored Gog-Le-Hi-Te estuarine wetland. Ecological Applications 6:38-56.

Staus, N.L., J.R. Strittholt, D.A. DellaSala, and R. Robinson. 2002. Rate and pattem of forest disturbance in the Klamath-Siskiyou ecoregion, USA between 1972 and 1992. Landscape Ecology 17:455-470.

Sudol, M. F., and R. F. Ambrose. 2002. The US Clean Water Act and habitat replacement: evaluation of mitigation sites in Orange County, California, USA. Environmental Management 30:727-734.

Tilton, D. L. 1995. Integrating wetlands into planned landscapes. Landscape and Urban Planning 32:205-209. 
United States Army Corps of Engineers. 1987. Corps of engineers wetlands delineation manual. Technical report Y-87-1. U.S. Army Corps of Engineer Waterways Experiment Station, Vicksburg, Mississippi, 169 pp.

United States Environmental Protection Agency. 2003. Great Lakes areas of concern: Cuyahoga River. Available: http://www.epa.gov/glnpo/aoc/cuyahoga.html.

White, D. A., and M. S. Fennessy. 2005. Modeling the suitability of wetland restoration potential at the watershed scale. Journal of Ecological Engineering 24:357-375.

Zampella, R. A., and K. J. Laidig. 2003. Functional equivalency of natural and excavated coastal plain ponds. Wetlands 23:860-876.

Zedler, J. B. 1996. Ecological issues in wetland mitigation: an introduction to the forum. Ecological Applications 6:33-37. 
APPENDIX A

PROJECT LOCATION INFORMATION 


\begin{tabular}{|c|c|c|c|c|c|}
\hline Project \# & Project Name & $\begin{array}{l}\text { Impacts } \\
\text { Latitude }\end{array}$ & $\begin{array}{l}\text { Impacts } \\
\text { Longitude }\end{array}$ & $\begin{array}{l}\text { Mitigation } \\
\text { Latitude }\end{array}$ & $\begin{array}{l}\text { Mitigation } \\
\text { Longitude }\end{array}$ \\
\hline 1 & I-80 Bridges & 411526.24 & -81337.46 & 412129.35 & -813629.86 \\
\hline 2 & Four Seasons & 411651.30 & -813952.17 & 411651.30 & -813952.17 \\
\hline 3 & Harvard Road & 41270.96 & -812935.65 & 41270.96 & -812935.65 \\
\hline 4 & Kerruish & 412536.32 & -81339.47 & 412536.32 & -81339.47 \\
\hline $5 a$ & Lombardo North & 412410.25 & -813937.94 & 411922.98 & -815450.34 \\
\hline $5 b$ & Lombardo South & 412410.25 & -813937.94 & 411829.80 & -815530.44 \\
\hline 6 & OTC & 411624.29 & -81383.95 & 412543.86 & -813953.81 \\
\hline 7 & Twinsburg & 411930.40 & -812638.67 & 411930.40 & -812638.67 \\
\hline 8 & Whitlach & 411826.85 & -81262.59 & 411826.85 & -81262.59 \\
\hline 9 & Admore Drive & 410914.02 & -812247.12 & 410914.02 & -812247.12 \\
\hline 10 & Kent State & 410817.27 & -812022.24 & 410817.27 & -812022.24 \\
\hline 11 & Rapids Road & 41275.79 & -810930.49 & 41275.79 & -810930.49 \\
\hline 12 & Geauga Lake & 412118.26 & -81235.29 & 412118.26 & -81235.29 \\
\hline 13 & Whisp Meadows & 411950.45 & -814233.74 & \multicolumn{2}{|c|}{ Mitigation Bank * } \\
\hline 14 & Dayton Freight & 410638.46 & -812259.29 & \multicolumn{2}{|c|}{ Mitigation Bank* } \\
\hline 15 & Nesbitt Road & 411948.80 & -813424.48 & \multicolumn{2}{|c|}{ Mitigation Bank * } \\
\hline 16 & Ambina Road & 412223.50 & -812823.20 & \multicolumn{2}{|c|}{ Preservation Only** } \\
\hline 17 & Old River Bed & 412926.51 & -814325.82 & \multicolumn{2}{|c|}{ Mitigation Bank * } \\
\hline 18 & North Point & 410954.39 & -81306.26 & \multicolumn{2}{|c|}{ Mitigation Bank } \\
\hline 19 & Cameratta & 412434.01 & -813831.76 & \multicolumn{2}{|c|}{ Mitigation Bank } \\
\hline 20 & GOJO & 411039.62 & -812959.43 & \multicolumn{2}{|c|}{ Mitigation Bank* } \\
\hline 21 & Hudson Industrial & 411243.66 & -812542.03 & \multicolumn{2}{|c|}{ Preservation Only** } \\
\hline 22 & Seabreeze & 41135.87 & -813832.80 & \multicolumn{2}{|c|}{ Mitigation Bank * } \\
\hline 23 & Wilcox & 411441.36 & -812145.00 & 41144136 & -812145.00 \\
\hline
\end{tabular}

* Mitigation requirements were met through the purchase of credits at a mitigation bank.

** Mitigation requirements were met entirely by preserving existing wetlands.

Table A.1 Latitude and longitude coordinates for impacted and mitigation wetlands for each project. Projects that mitigated at a bank or through preservation only were not visited and therefore no location is given. 
APPENDIX B

PROJECT ANALYSES AND SPECIAL CONSIDERATIONS 


\begin{tabular}{|c|c|c|c|c|c|}
\hline $\begin{array}{l}\text { Project } \\
\text { Number }\end{array}$ & Project Name & $\begin{array}{c}\text { Permit } \\
\text { Compliance }\end{array}$ & $\begin{array}{c}\text { Wetland Number } \\
\text { and Size }\end{array}$ & $\begin{array}{l}\text { Vegetation } \\
\text { Types }\end{array}$ & $\begin{array}{c}\text { Restoration } \\
\text { Potential } \\
\end{array}$ \\
\hline 1 & I-80 Bridges & $\mathbf{X}$ & $\mathbf{X}$ & $\mathbf{X}$ & $\mathbf{X}$ \\
\hline 2 & Four Seasons & $\mathbf{X}$ & $\mathbf{X}$ & $\mathbf{X}$ & $\mathbf{X}$ \\
\hline 3 & Harvard Road & $\mathbf{X}$ & $\mathbf{X}$ & $\mathbf{X}$ & $\mathbf{X}$ \\
\hline 4 & Kerruish & $\mathbf{x}$ & $\mathbf{X}$ & $\mathbf{X}$ & $\mathbf{X}$ \\
\hline $5 a$ & Lombardo North & $\mathbf{X}$ & $\mathbf{X}$ & $\mathbf{X}$ & \\
\hline $5 b$ & Lombardo South & $\mathbf{X}$ & $\mathbf{X}$ & $\mathbf{X}$ & \\
\hline 6 & OTC & $\mathbf{X}$ & $\mathbf{X}$ & $\mathbf{X}$ & $\mathbf{X}$ \\
\hline 7 & Twinsburg & $\mathbf{X}$ & $\mathbf{X}$ & $\mathbf{X}$ & $\mathbf{X}$ \\
\hline 8 & Whitlach & $\mathbf{X}$ & $\mathbf{X}$ & $\mathbf{X}$ & $\mathbf{X}$ \\
\hline 9 & Admore Drive & $\mathbf{X}$ & $\mathbf{X}$ & $\mathbf{X}$ & $\mathbf{X}$ \\
\hline 10 & Kent State & $\mathbf{x}$ & $\mathbf{x}$ & $\mathbf{x}$ & $\mathbf{X}$ \\
\hline 11 & Rapids Road & $\mathbf{x}$ & $\mathbf{X}$ & $\mathbf{X}$ & $\mathbf{X}$ \\
\hline 12 & Geauga Lake & $\mathbf{X}$ & $\mathbf{x}$ & $\mathbf{X}$ & $\mathbf{X}$ \\
\hline 13 & Whisp Meadows & $\mathbf{X}$ & $\mathbf{X}^{*}$ & & \\
\hline 14 & Dayton Freight & $\mathbf{X}$ & $\mathbf{X}^{*}$ & & \\
\hline 15 & Nesbitt Road & $\mathbf{X}$ & $X^{*}$ & & \\
\hline 16 & Ambina Road & $\mathbf{X}$ & $X^{*}$ & & \\
\hline 17 & Old River Bed & $\mathbf{X}$ & $X^{*}$ & & \\
\hline 18 & North Point & $\mathbf{X}$ & $\mathbf{X}^{*}$ & & \\
\hline 19 & Cameratta & $\mathbf{X}$ & $X^{*}$ & & \\
\hline 20 & GOJO & $\mathbf{X}$ & $\mathbf{X}^{*}$ & & \\
\hline 21 & Hudson Industrial & $\mathbf{X}$ & $\mathbf{X}^{*}$ & & \\
\hline 22 & Seabreeze & $\mathbf{X}$ & $\mathbf{X}^{*}$ & & \\
\hline 23 & Wilcox & $\mathbf{X}$ & $X^{*}$ & & \\
\hline
\end{tabular}

* For comparison of number and size of impacted versus mitigation wetlands, it was assumed that wetland credits purchased at a mitigation bank were located within a single wetland.

** These two projects were combined for the calculation of mitigation wetland perimeter land uses

Continued

Table B.1 Analyses that were conducted for each project. 
Table B. 1 continued

\begin{tabular}{c|lccc}
\hline $\begin{array}{c}\text { Project } \\
\text { Number }\end{array}$ & Project Name & $\begin{array}{c}\text { Land Use } \\
\text { Analysis }\end{array}$ & $\begin{array}{c}\text { Wetland Perimeter } \\
\text { Land Uses }\end{array}$ & $\begin{array}{c}\text { Amphibian } \\
\text { Potential }\end{array}$ \\
\hline 1 & I-80 Bridges & $\mathbf{X}$ & $\mathbf{X}$ & $\mathbf{X}$ \\
2 & Four Seasons & $\mathbf{X}$ & $\mathbf{X}$ & $\mathbf{X}$ \\
3 & Harvard Road & $\mathbf{X}$ & $\mathbf{X}$ & $\mathbf{X}$ \\
4 & Kerruish & $\mathbf{X}$ & $\mathbf{X}$ & $\mathbf{X}$ \\
$5 \mathrm{a}$ & Lombardo North & $\mathbf{X}$ & $\mathbf{X}$ & $\mathbf{X}$ \\
$5 \mathrm{~b}$ & Lombardo South & $\mathbf{X}$ & $\mathbf{X}$ & $\mathbf{X}$ \\
6 & OTC & $\mathbf{X}$ & $\mathbf{X}$ & $\mathbf{X}$ \\
7 & Twinsburg & $\mathbf{X}$ & $\mathbf{X}$ & \\
8 & Whitlach & $\mathbf{X}$ & & \\
9 & Admore Drive & & & \\
10 & Kent State & & & \\
11 & Rapids Road & & & \\
12 & Geauga Lake & & & \\
13 & Whisp Meadows & & & \\
14 & Dayton Freight & & & \\
15 & Nesbitt Raad & & & \\
16 & Ambina Road & & & \\
17 & Old River Bed & & & \\
18 & North Point & & & \\
19 & Cameratta & & & \\
20 & GOJO & & & \\
21 & Hudson Industrial & & & \\
22 & Seabreeze & & & \\
23 & Wilcox & & & \\
\hline
\end{tabular}

* For comparison of number and size of impacted versus mitigation wetlands, it was assumed that wetland credits purchased at a mitigation bank were located within a single wetland.

** These two projects were combined for the calculation of mitigation wetland perimeter land uses 


\begin{tabular}{|c|c|c|c|c|c|}
\hline Project \# & Project Name & Open Water & Wetlands** & GIS*** & Watershed $* * * *$ \\
\hline 1 & I-80 Bridges & & & & \\
\hline 2 & Four Seasons & $\mathbf{X}$ & $\mathbf{X}$ & & \\
\hline 3 & Harvand Road & & & & \\
\hline 4 & Kernish & $\mathbf{X}$ & & & \\
\hline $5 a$ & Lombardo North & & & & \\
\hline $5 b$ & Lombardo South & & & & \\
\hline 6 & OTC & & & & \\
\hline 7 & Twinsburg & & $\mathbf{X}$ & & \\
\hline 8 & Whitlach & & & & \\
\hline 9 & Admore Drive & & & & \\
\hline 10 & Kent State & & & & \\
\hline 11 & Rapids Road & & & & \\
\hline 12 & Geauga Lake & & $\mathbf{X}$ & $\mathbf{X}$ & $\mathbf{X}$ \\
\hline 13 & Whisp Meadows & & & & \\
\hline 14 & Dayton Freight & & & & \\
\hline 15 & Nesbitt Road & & & & \\
\hline 16 & Ambina Road & & & & \\
\hline 17 & Old River Bed & & & & \\
\hline 18 & North Point & & & & \\
\hline 19 & Cameratta & & & & \\
\hline 20 & GOJO & & & & \\
\hline 21 & Hudson Industrial & & & & \\
\hline 22 & Seabreeze & & & & \\
\hline 23 & Wilcox & & & & \\
\hline
\end{tabular}

* Mitigation wetland size was over-estimated because deep open water habitat (non-wetland) was included in wetland delineation

** Mitigation wetland size was over-estimated because natural wetlands located within or adjacent to mitigation wetlands were included in delineation of mitigation area

*** The area of forested vernal pools were estimated using an as-built survey and GIS techniques **** A small portion of wetland associated with this project was located outside of the watershed but was included within compliance calculations

Table B.2 Special circumstances that were noted during delineation of mitigation wetlands and calculation of permit compliance. 
APPENDIX C

ANALYSIS OF GENERIC LANDSCAPES USING FRAGSTATS 


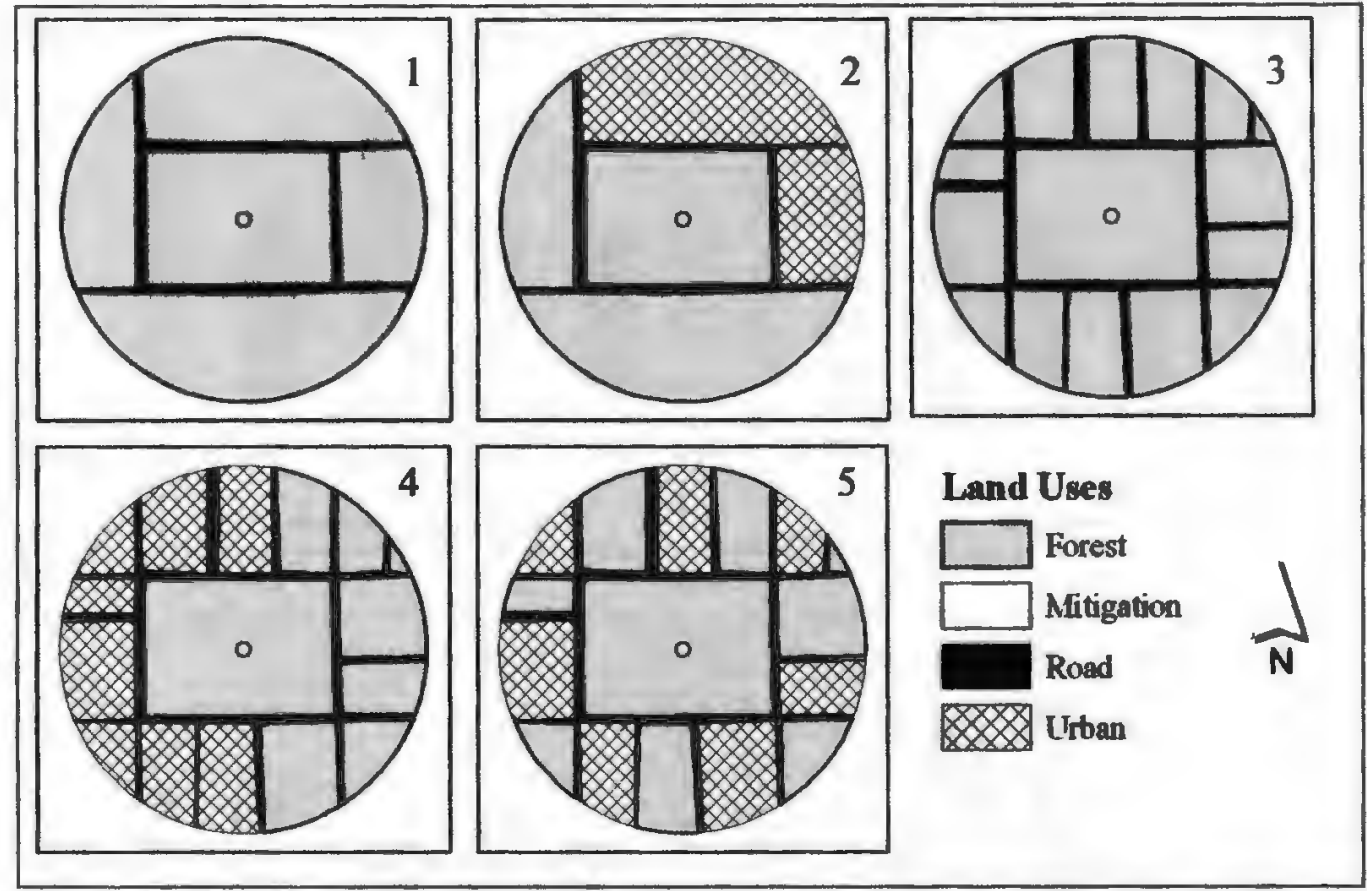

Figure C.1 Generic landscapes that were analyzed using FRAGSTATS to calculate landscape metrics for general landscape composition and amphibian potential analysis (see Figure C.2). 

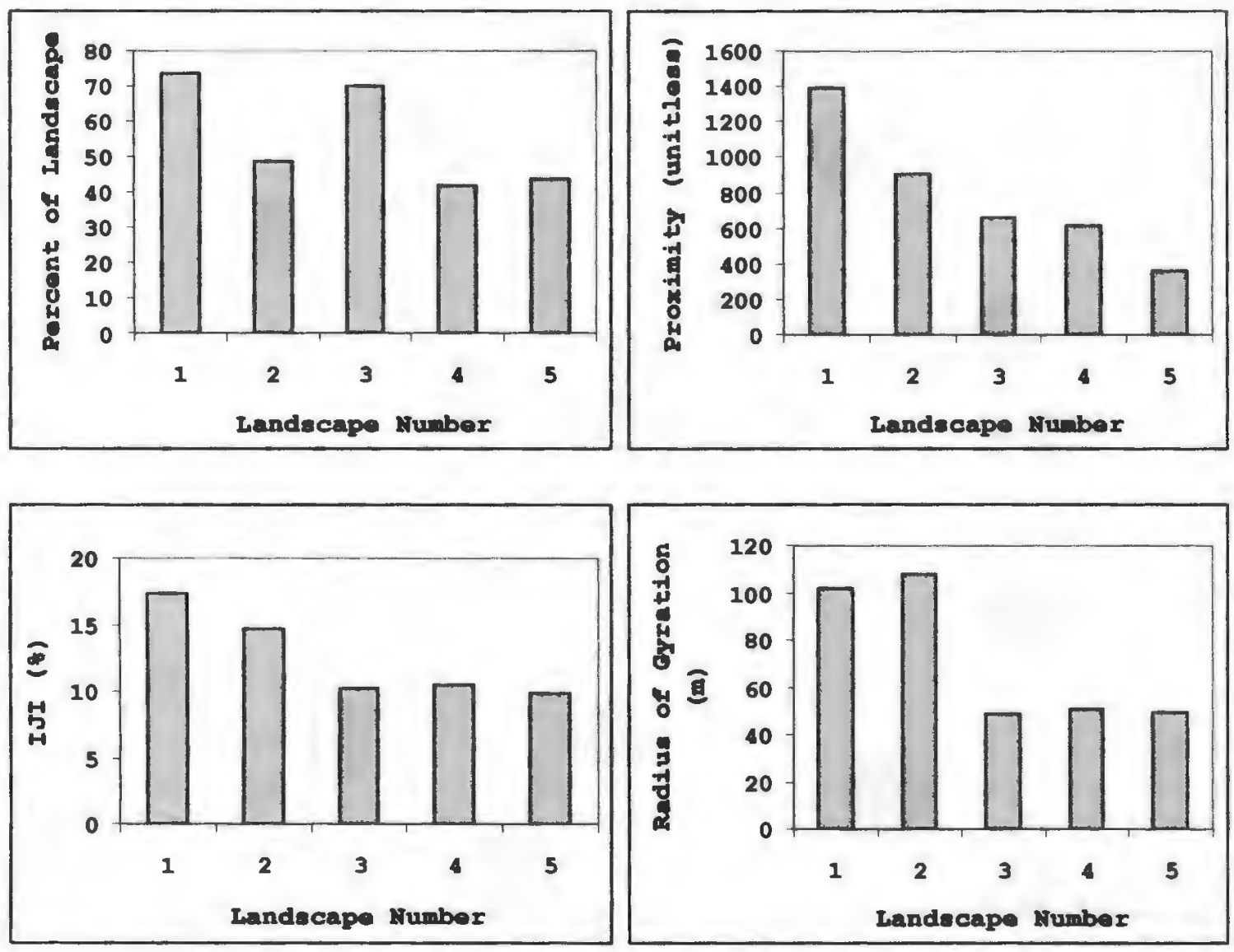

Figure C.2 Results for four different landscape metrics that were calculated by FRAGSTATS using the generic landscapes shown in Figure C.1. 


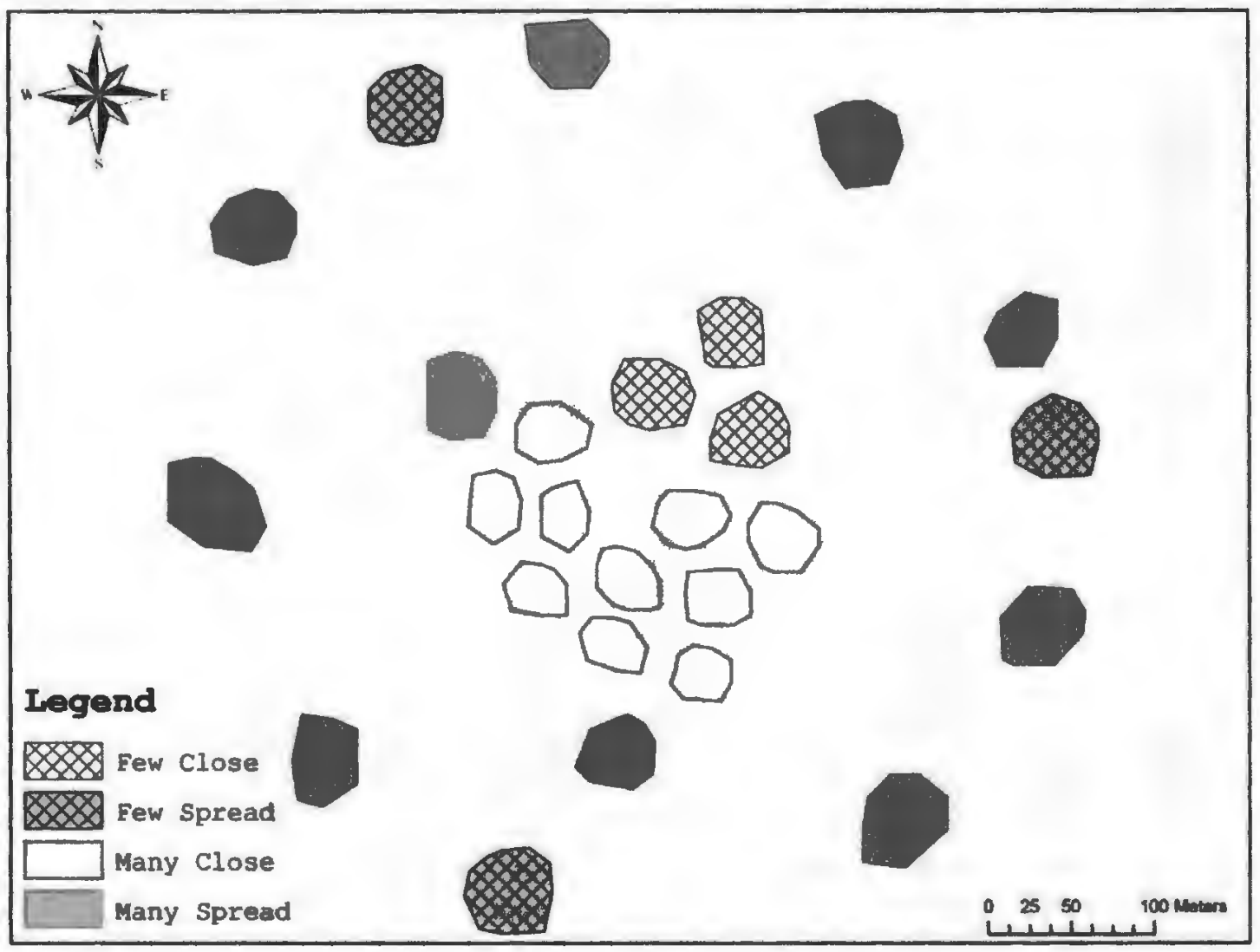

Figure C.3 Generic landscapes that were analyzed using FRAGSTATS to give landscape metrics (see Figure C.4). 

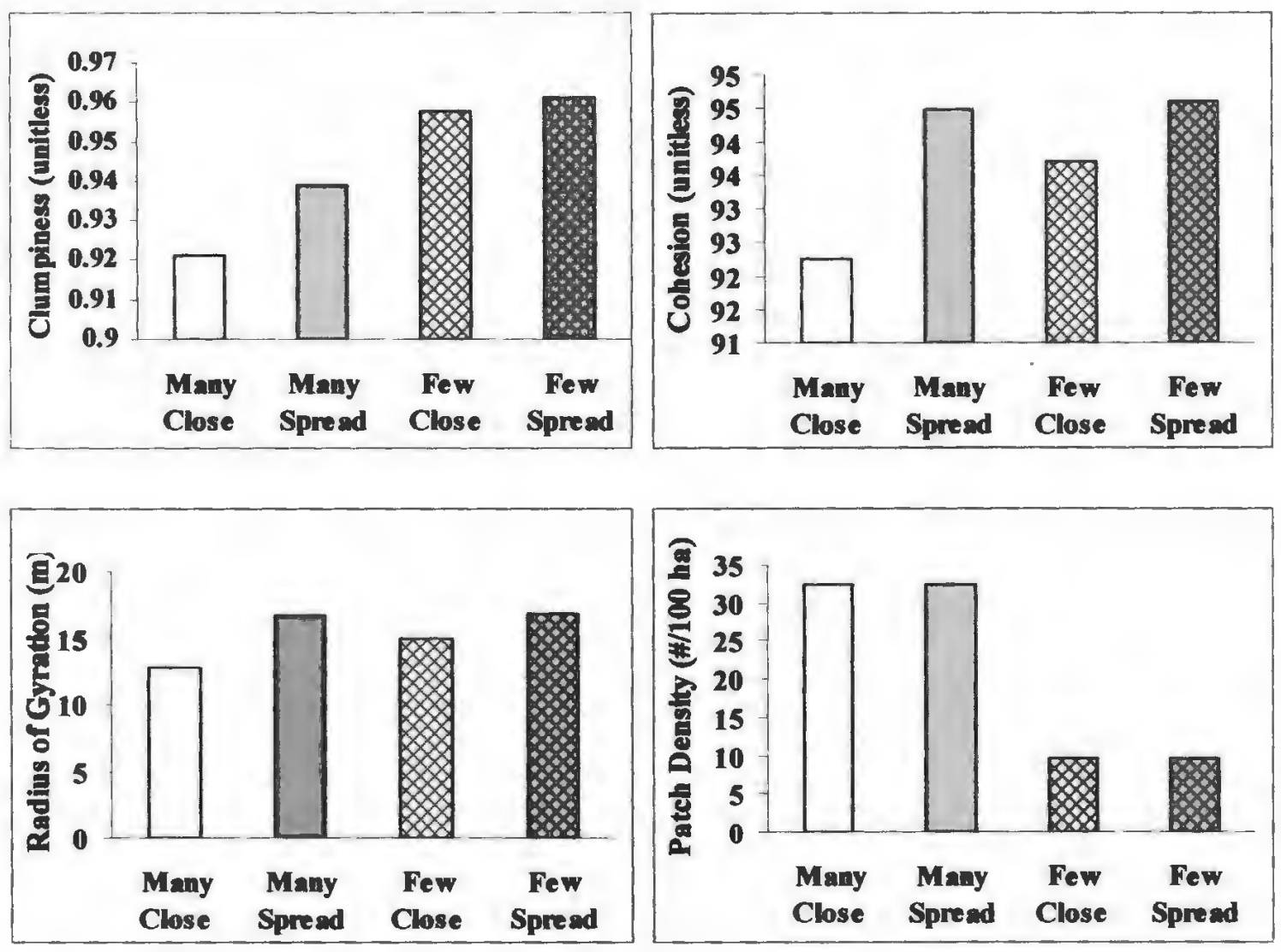

Figure C.4 Results for four different landscape metrics that were calculated by FRAGSTATS using the generic landscapes shown in Figure C.3. 
APPENDIX D

LANDSCAPE METRIC EQUATIONS 
The equations for landscape metrics as calculated by the FRAGSTATS software package are listed below as defined within the FRAGSTATS documentation (McGarigal and others 2002). See McGarigal and others (2002) for a more detailed description of these metrics.

Percent of Landscape $(\%)=\mathrm{P}_{i}=\frac{\sum_{j=1}^{n} a_{i j}}{A}(100)$

where: $\mathrm{P}_{i}=$ proportion of landscape occupied by patch type (land use) $i$

$$
\begin{aligned}
& \mathrm{a}_{i j}=\operatorname{area}\left(\mathrm{m}^{2}\right) \text { of patch } i j \\
& \mathrm{~A}=\text { total landscape area }\left(\mathrm{m}^{2}\right)
\end{aligned}
$$

Patch Density (\# patches $/ 100 \mathrm{ha})=\frac{n_{i}}{A}(10,000)(100)$

where: $\mathrm{n}_{i}=$ number of patches in the landscape of patch type (land use) $i$

$$
A=\text { landscape area }\left(\mathrm{m}^{2}\right)
$$


Radius of Gyration (m) $=\sum_{r=1}^{z} z^{h_{i j r}}$

where: $\boldsymbol{h}_{i j r}=$ distance $(\mathrm{m})$ between cell $i j r$ (located within patch $i j$ ) and the centroid of patch $i j$ (the average location), based on cell center to center distance

$z=$ number of cells in patch $i j$

$r=$ pixel $\mathbf{r}$

Proximity Index (unitless) $=\sum_{s=1}^{n} \frac{a_{i j s}}{h_{i j s}^{2}}$

where: $a_{i j s}=\operatorname{area}(\mathrm{m} 2)$ of patch $i j s$ within specified neighborhood (m) of patch $i j$

$h_{i j s}=$ distance (m) between patch $i j s$ and patch $i j s$, based upon patch edge to edge distance, computed from cell center to cell center

Interspersion and Juxtaposition Index (\%)=IJI $=\frac{\sum_{k=1}^{m}\left[\left(\frac{e_{i k}}{\sum_{k=1}^{m} e_{i k}}\right) \ln \left(\frac{e_{i k}}{\sum_{k=1}^{m} e_{i k}}\right)\right]}{\ln (m-1)}(100)$

where: $\mathrm{e}_{i k}=$ total length (m) of edge in landscape between patch types (land uses) $i$ and $j$ $\mathrm{m}=$ number of patch types (land uses) present in the landscape 
APPENDIX E

LAND USE CLASSES AND DIGITIZATION PROTOCOL 


\begin{tabular}{|c|c|}
\hline Land Use Class & Description \\
\hline Agriculture & $\begin{array}{l}\text { Actively farmed row crops. Included barns and all farm buildings except for } \\
\text { farmhouses which were included within the Residential class. Did not include hay } \\
\text { fields which were included in the Mowed class. }\end{array}$ \\
\hline Construction & $\begin{array}{l}\text { Areas under active construction for which the planned land use was unclear. Included } \\
\text { dirt roads and all areas with exposed, unvegetated soil (excluding plowed agriculture } \\
\text { fields). }\end{array}$ \\
\hline Forest & $\begin{array}{l}\text { All forests. Small groups of trees (1-15) were not delineated as forest but were } \\
\text { included within the nearby land use class. Some ephemeral wetlands and streams } \\
\text { may have been included within the Forest class. }\end{array}$ \\
\hline Industrial & Included all industrial complexes, office buildings, and associated parking lots. \\
\hline $\begin{array}{l}\text { Mitigation } \\
\text { Wetland }\end{array}$ & $\begin{array}{l}\text { Mitigation wetlands that were delineated in the field using the Army Corps of } \\
\text { Engineers protocol (ACOE 1987). }\end{array}$ \\
\hline Mowed & $\begin{array}{l}\text { Included recently abandoned farm fields, hay fields, orchards, roadside grassways, } \\
\text { and all areas that were clearly mowed. Small yards associated with residential areas } \\
\text { were included in the Residential class. }\end{array}$ \\
\hline Oldfield & $\begin{array}{l}\text { Oldfield was defined as early successional, upland, herbaceous vegetation. Oldfield } \\
\text { is generally found on an area that has recently been abandoned by humans. } \\
\text { Oldfield, prairie, scrub/shrub upland, and patchy, very early successional forest. Also } \\
\text { included thin (<10ft wide) strips of trees between other land use classes. }\end{array}$ \\
\hline Park & $\begin{array}{l}\text { Small, paved walkways within parks were included in the Park class. Also included } \\
\text { recreational facilities such as temnis courts and baseball fields. Included cemeteries. }\end{array}$ \\
\hline Pond & Ponds and quarries that were comprised of $>90 \%$ open water. \\
\hline Residential & $\begin{array}{l}\text { All houses, apartment and condominium complexes, and associated yards and parking } \\
\text { lots. }\end{array}$ \\
\hline Road & $\begin{array}{l}\text { All paved and gravel roads that were }>10 \text { ft in width. Roads located within high } \\
\text { density residential areas were digitized at a scale of } 1: 5000 \text { to aid processing speed } \\
\text { (other land use classes were digitized at a scale of } 1: 2000-1: 4000 \text { ). Included } \\
\text { railways. }\end{array}$ \\
\hline Waterway & $\begin{array}{l}\text { All streams, ditches, rivers, and canals greater than } 10 \text { feet in width. Small islands } \\
\text { and sandbars were included in the Waterway class. }\end{array}$ \\
\hline Wetland & $\begin{array}{l}\text { All wetlands that were }<90 \% \text { open water. Some ephemeral wetlands, especially } \\
\text { forested wetlands, may have been excluded. }\end{array}$ \\
\hline
\end{tabular}

Table E.1 Descriptions of land use classes used for landscape analysis. 
APPENDIX F

LANDSCAPE AREAS 


\begin{tabular}{c|lccc}
\hline Project \# & Project Name & Rows & Columns & Area (ha) \\
\hline 1 & I-80 Bridges & 879 & 1317 & 115.8 \\
2 & Four Seasons & 777 & 828 & 64.3 \\
3 & Harvard Road & 907 & 878 & 79.6 \\
4 & Kerruish & 705 & 704 & 49.6 \\
5 & Lombardo & 887 & 774 & 68.7 \\
6 & OTC & 1038 & 1051 & 109.1 \\
7 & Twinsburg & 839 & 803 & 67.4 \\
8 & Whitlach & 754 & 742 & 55.9 \\
9 & Admore Drive & 669 & 665 & 44.5 \\
10 & Kent State & 665 & 666 & 44.3 \\
11 & Rapids Road & 741 & 667 & 49.4 \\
12 & Geauga Lake & 774 & 797 & 61.7 \\
\hline
\end{tabular}

Table F.1 Area of landscapes for impacted wetlands (1000 m). These landscapes were used only for wetland spatial configuration analysis, specifically the calculation of wetland density (\# wetlands/100 ha).

\begin{tabular}{c|lccc}
\hline Project \# & Project Name & Rows & Columns & Area (ha) \\
\hline 1 & I-80 Bridges & 245 & 287 & 7.0 \\
2 & Four Seasons & 243 & 309 & 7.5 \\
3 & Harvard Road & 312 & 250 & 7.8 \\
4 & Kerruish & 273 & 309 & 8.4 \\
$5 \mathrm{a}$ & Lombardo North & 284 & 293 & 8.3 \\
$5 b$ & Lombardo South & 269 & 330 & 8.9 \\
6 & OTC & 249 & 223 & 5.6 \\
7 & Twinsburg & 285 & 296 & 8.4 \\
8 & Whitlach & 261 & 253 & 6.6 \\
\hline
\end{tabular}

Table F.2 Area of landscapes for mitigation wetlands $(300 \mathrm{~m})$. These landscapes were used for wetland spatial configuration, general landscape setting, and amphibian potential analyses. 


\begin{tabular}{c|lccc}
\hline Project \# & Project Name & Rows & Columns & Area (ha) \\
\hline 1 & I-80 Bridges & 704 & 746 & 52.5 \\
2 & Four Seasons & 703 & 769 & 54.1 \\
3 & Harvard Road & 771 & 709 & 54.7 \\
4 & Kerruish & 732 & 768 & 56.2 \\
$5 \mathrm{a}$ & Lombardo North & 743 & 752 & 55.9 \\
$5 \mathrm{~b}$ & Lombardo South & 728 & 789 & 57.4 \\
6 & OTC & 709 & 682 & 48.4 \\
7 & Twinsburg & 744 & 756 & 56.2 \\
8 & Whitlach & 720 & 712 & 51.3 \\
9 & Admore Drive & 671 & 679 & 45.6 \\
10 & Kent State & 788 & 693 & 54.6 \\
11 & Rapids Road & 719 & 666 & 47.9 \\
12 & Geauga Lake & 790 & 709 & 56.0 \\
\hline
\end{tabular}

Table F 3 Area of landscapes for mitigation wetlands $(1000 \mathrm{~m})$. These landscapes were used for wetland spatial configuration and general landscape setting analyses. 
APPENDDX G

LAND USE MAPS 


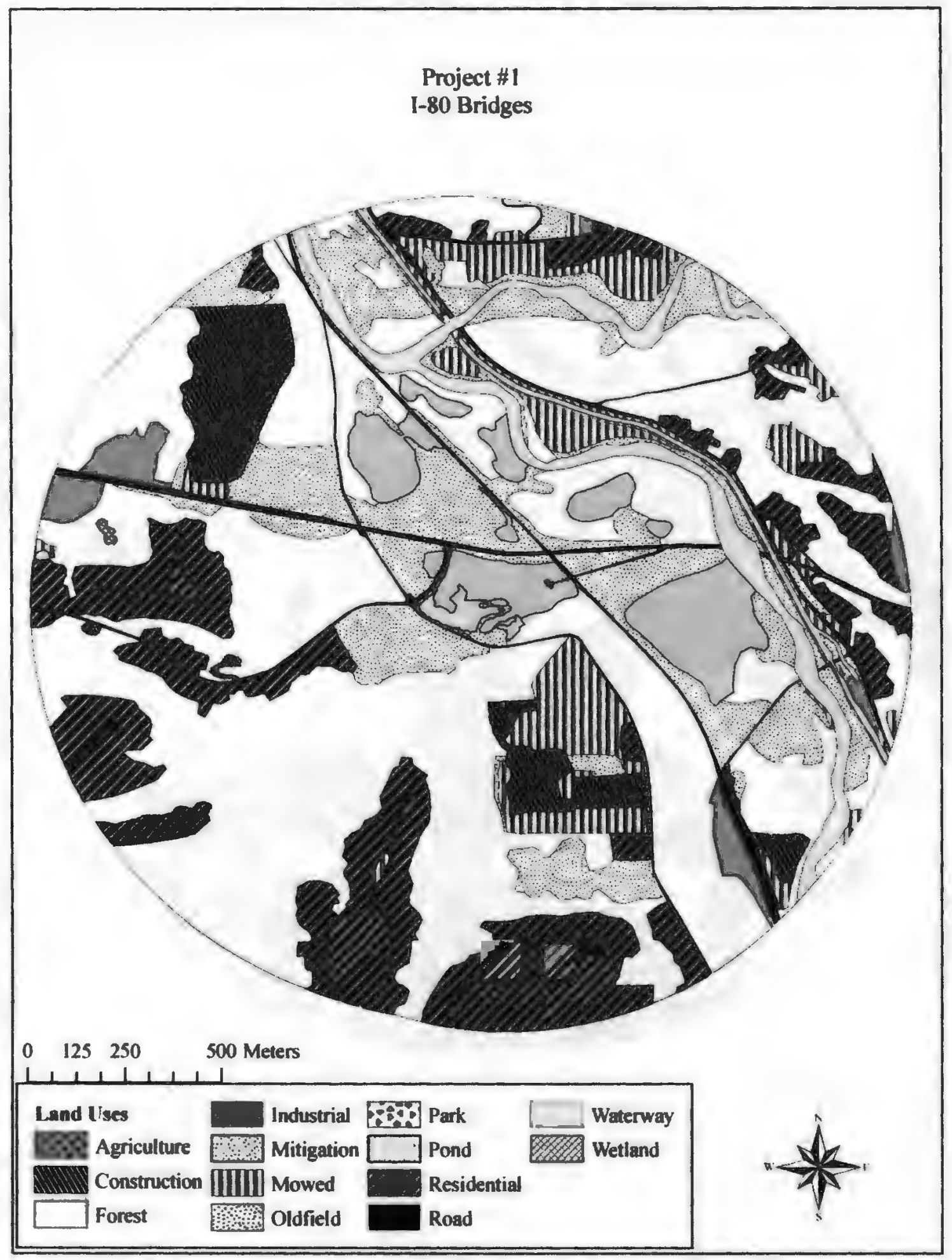

Figure G.1 $1000 \mathrm{~m}$ land use map for project \#1 . 


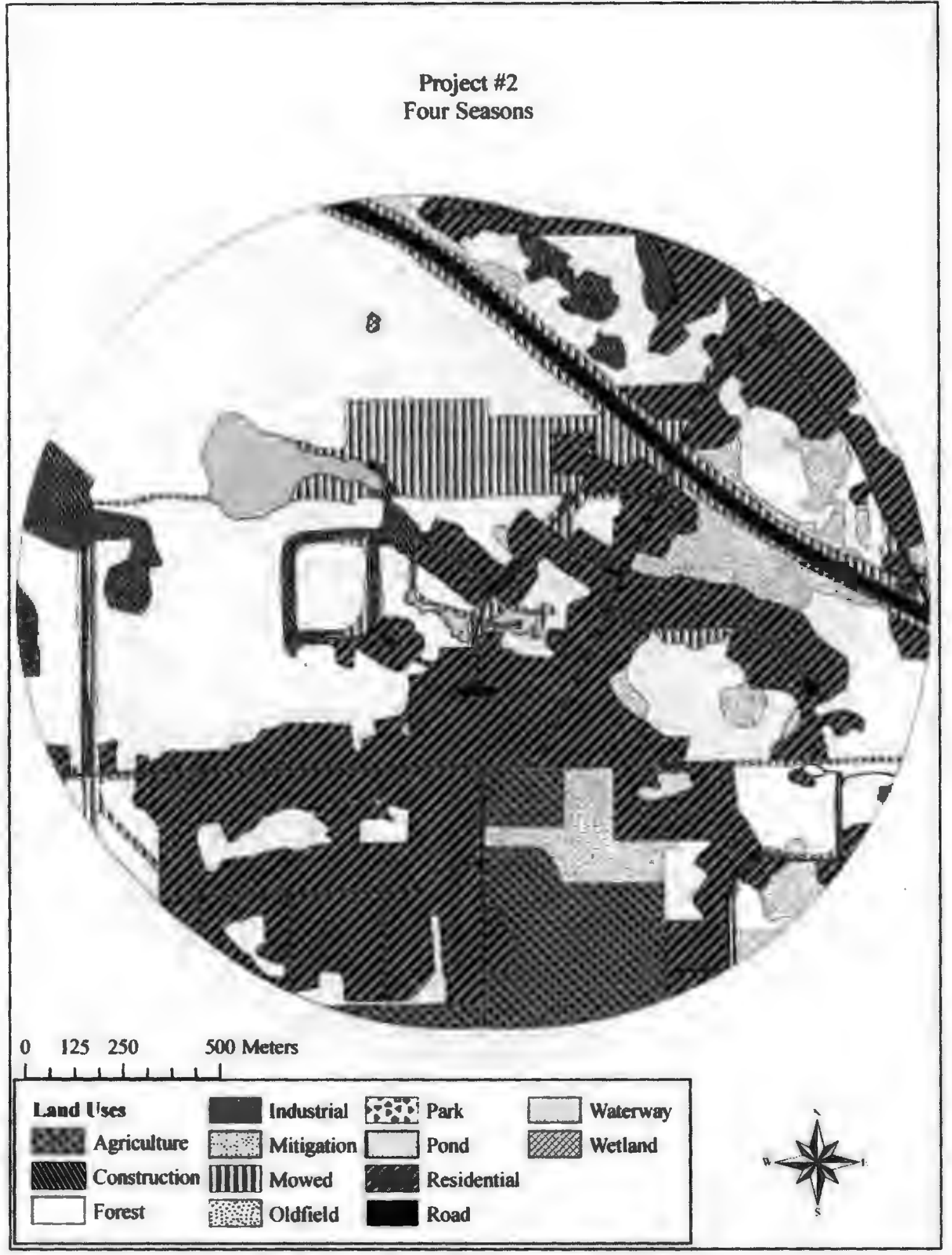

Figure G.2 $1000 \mathrm{~m}$ land use map for project \#2. 


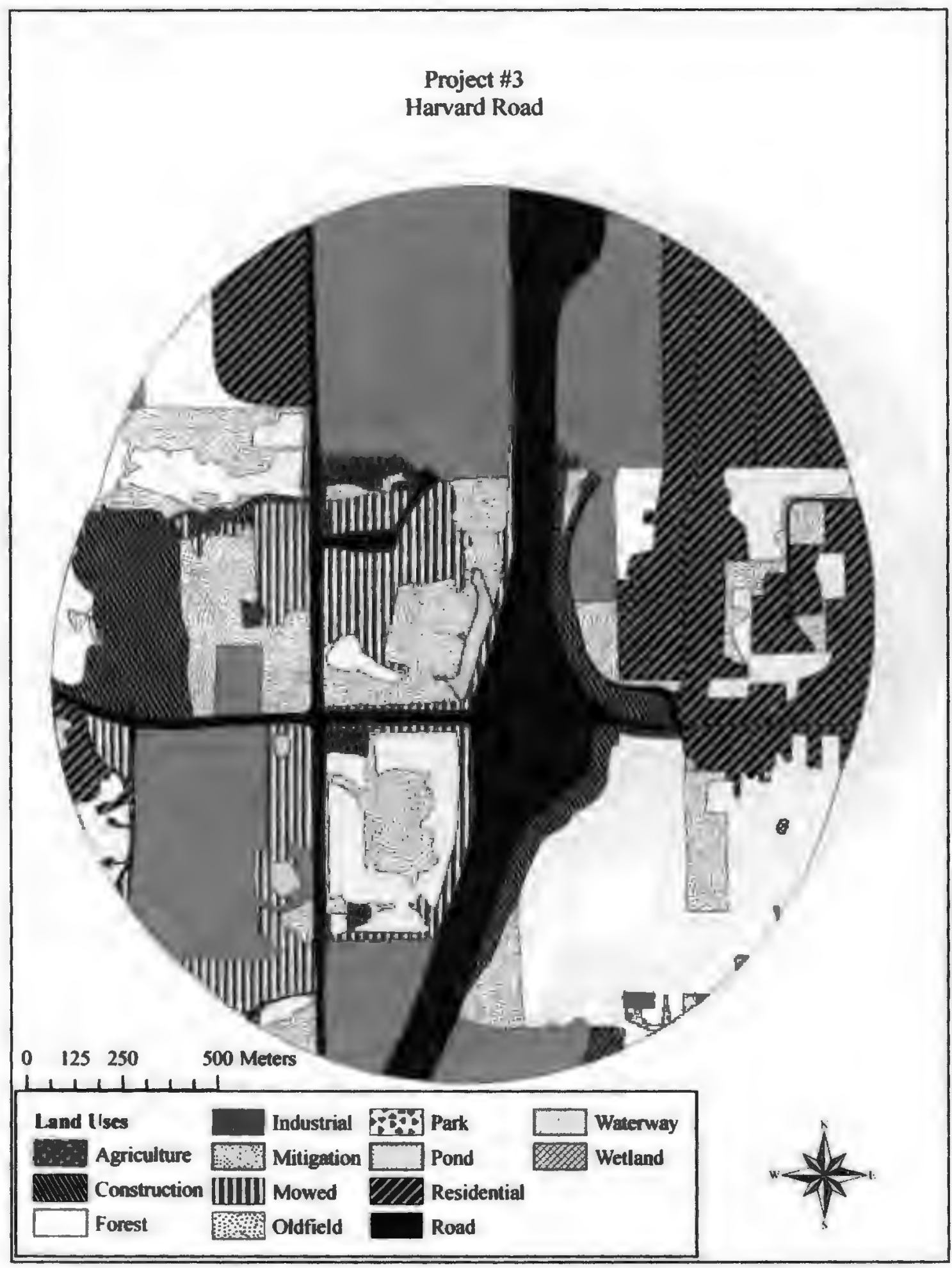

Figure G.3 $1000 \mathrm{~m}$ land use map for project \#3. 


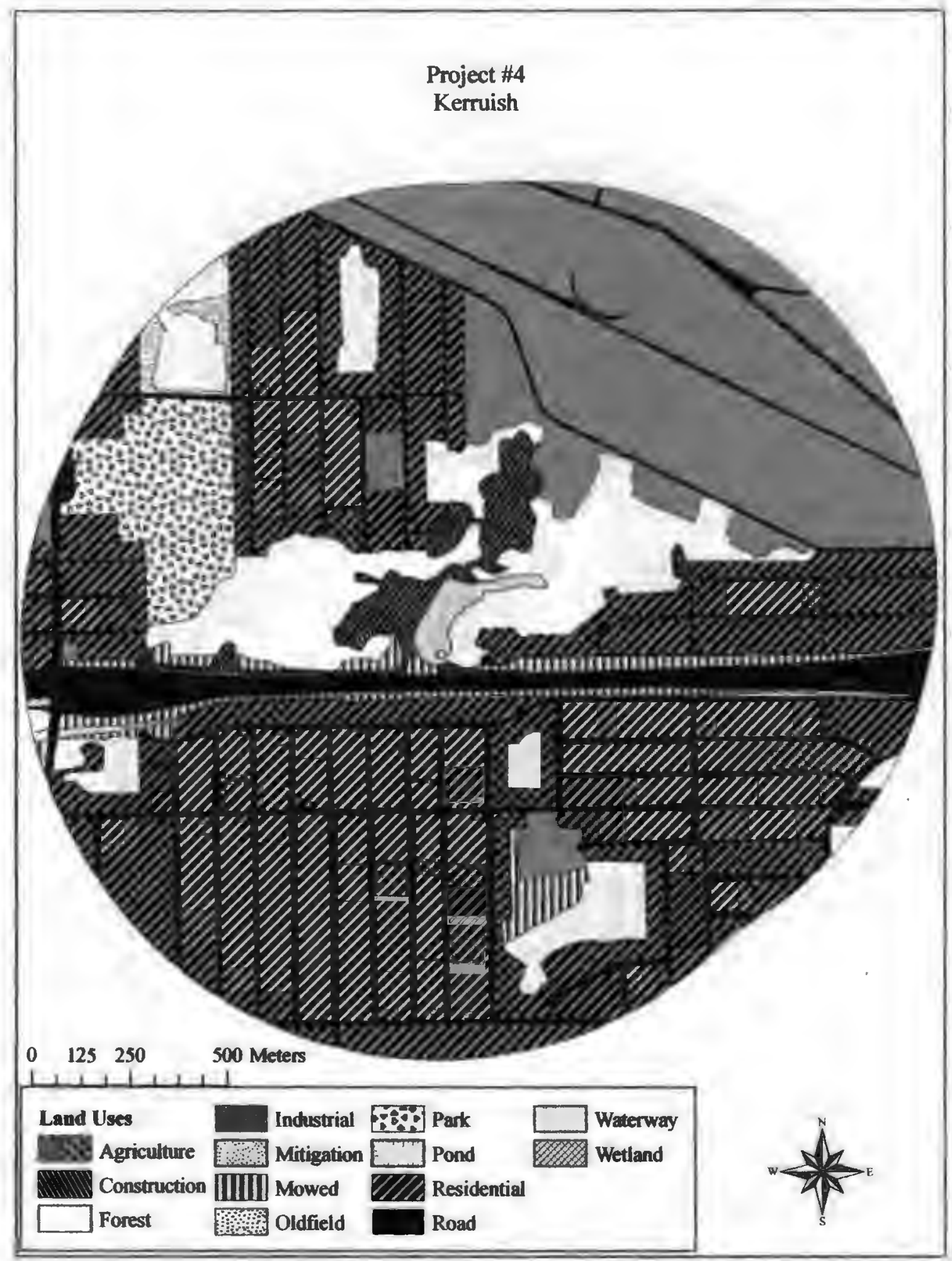

Figure G.4 $1000 \mathrm{~m}$ land use map for project \#4. 


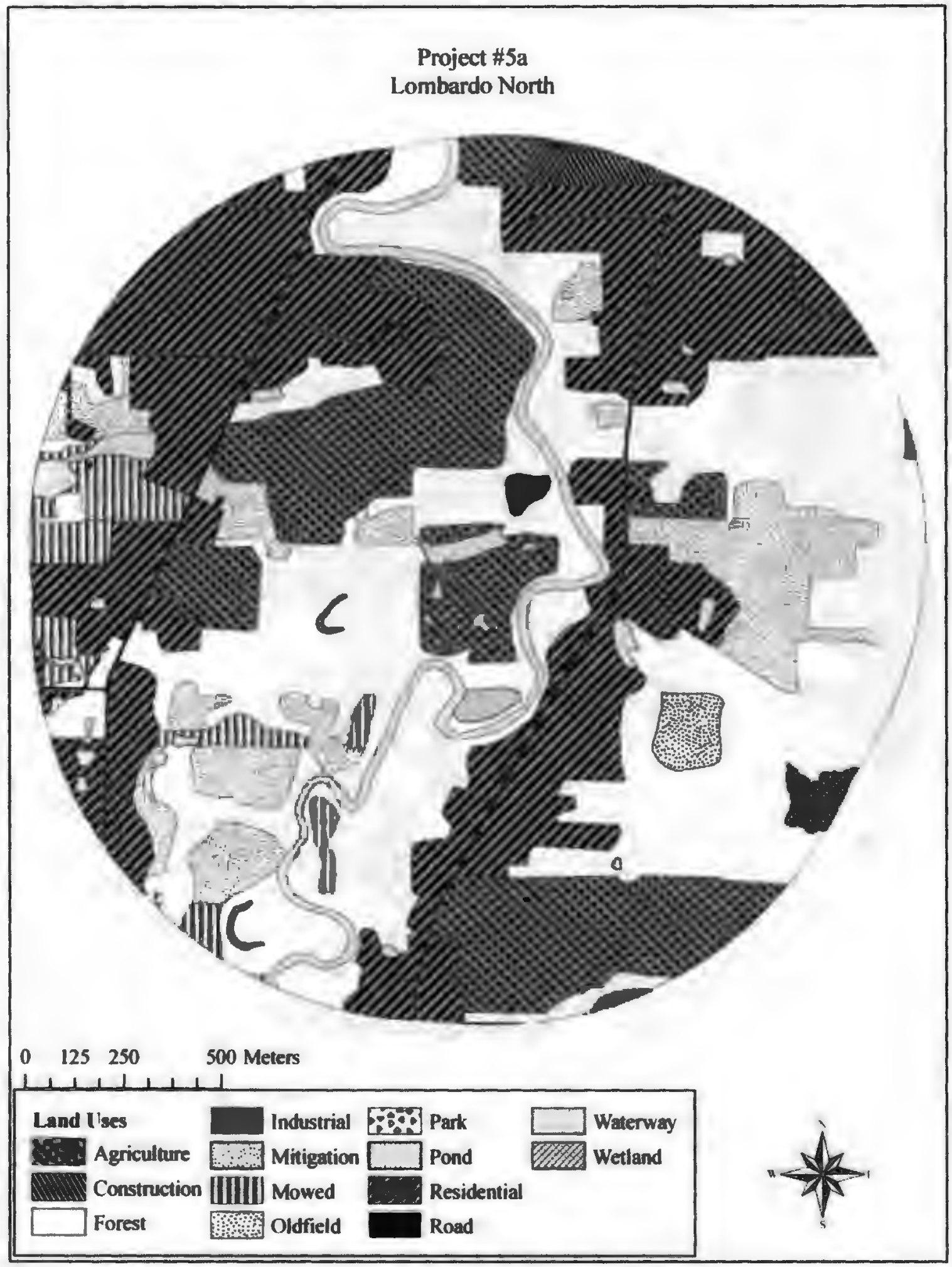

Figure G.5 $1000 \mathrm{~m}$ land use map for project \#5a. 


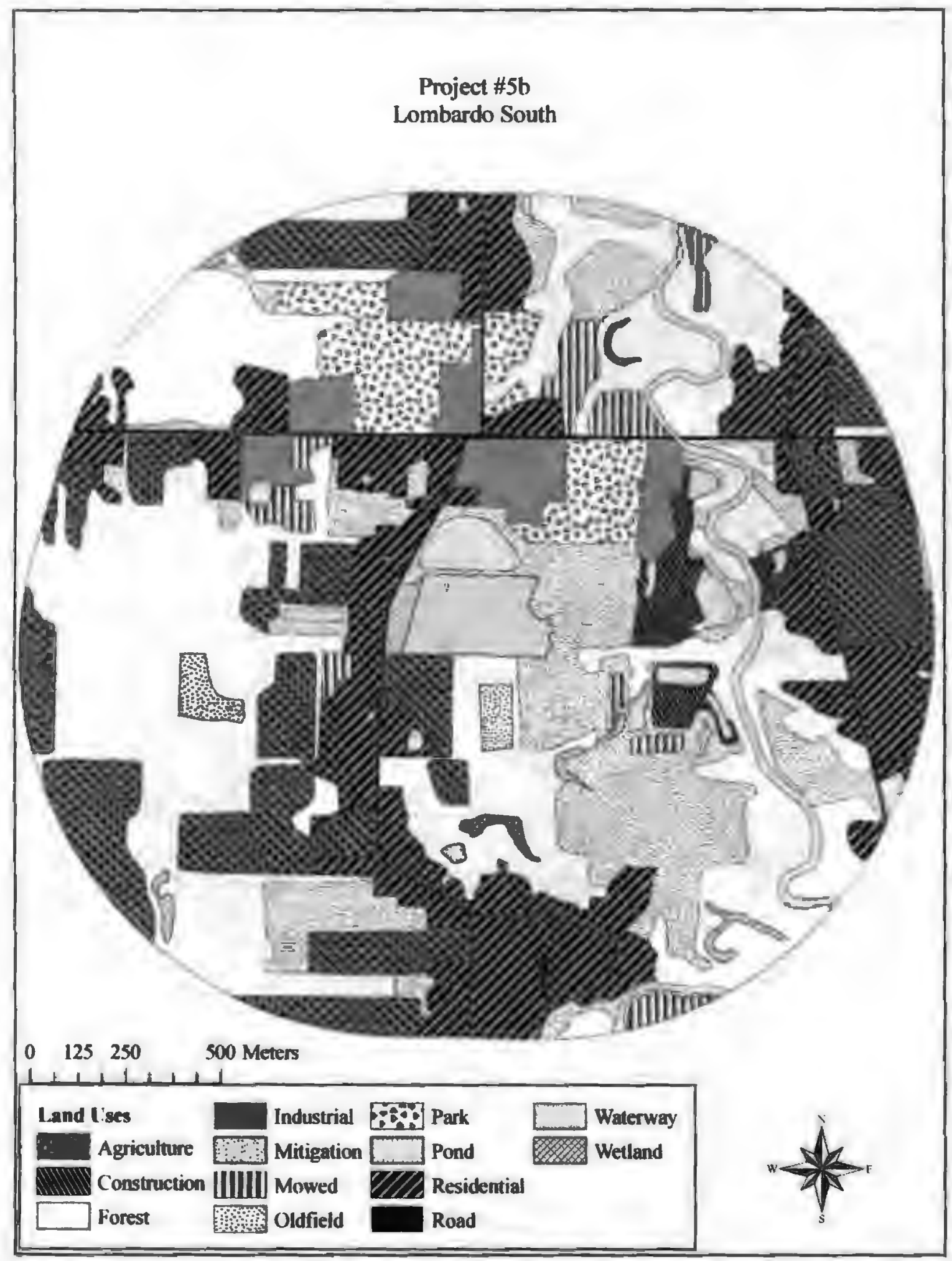

Figure G.6 $1000 \mathrm{~m}$ land use map for project \#5b. 


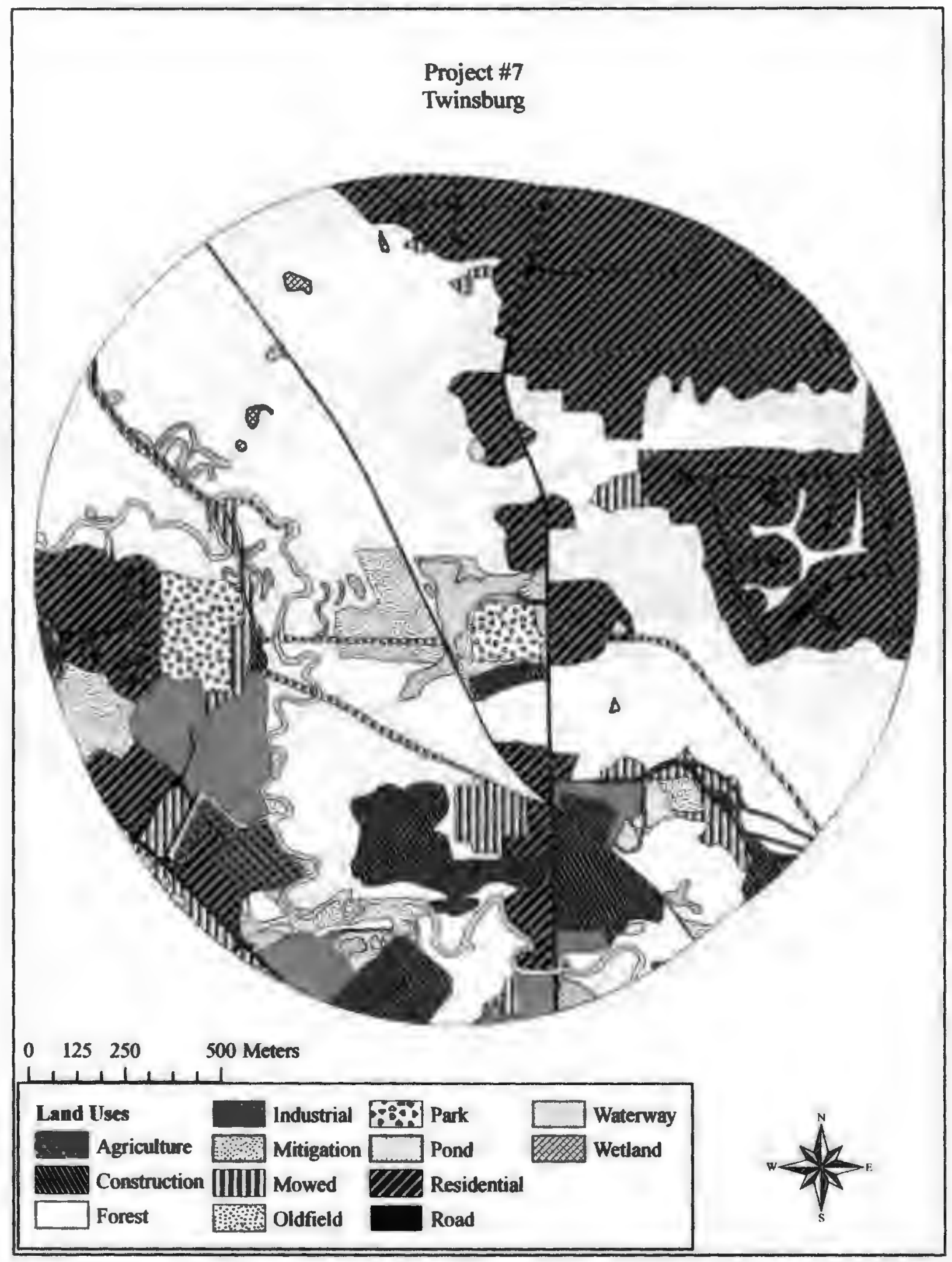

Figure G.7 $1000 \mathrm{~m}$ land use map for project \#7. 


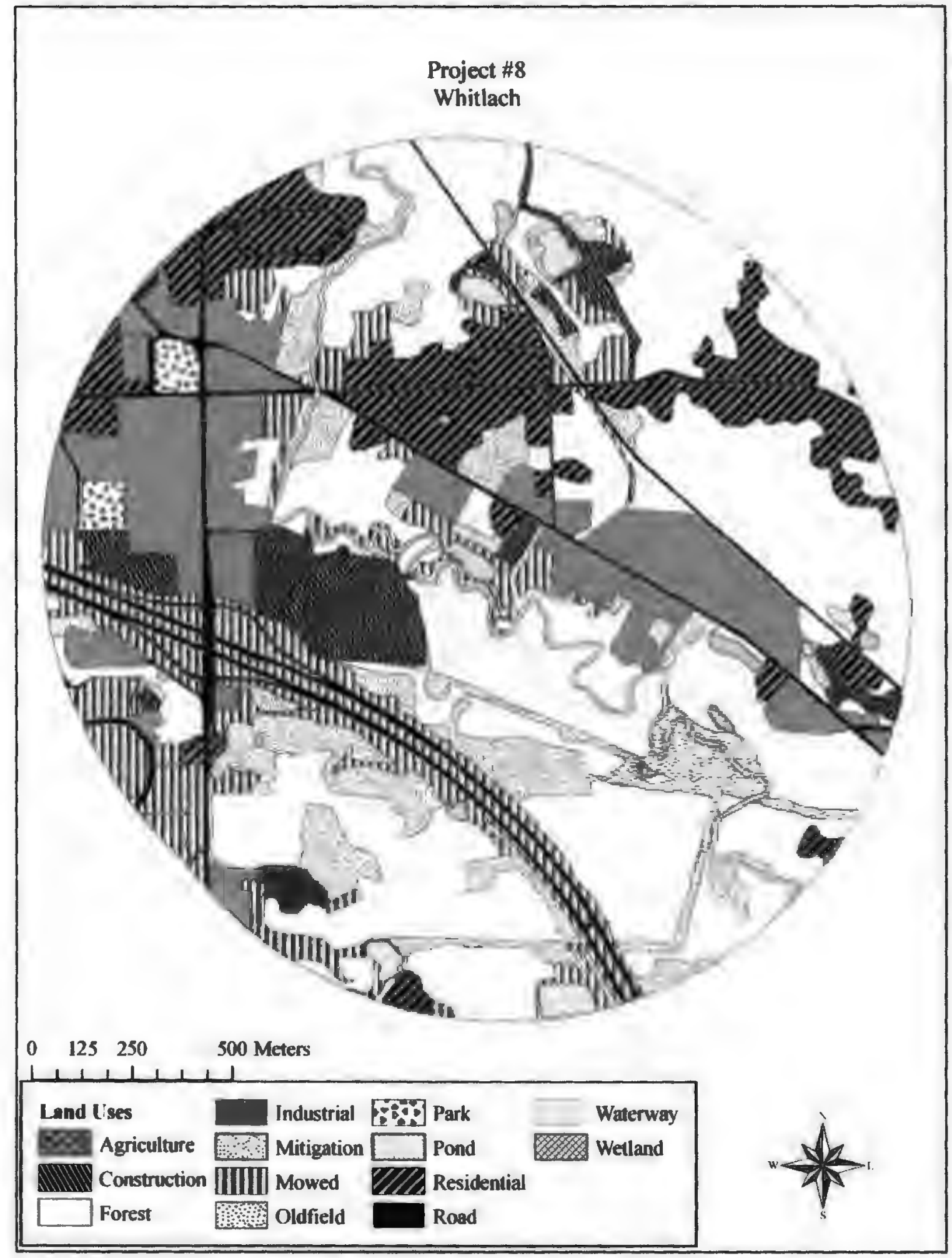

Figure G.8 $1000 \mathrm{~m}$ land use map for project \#8 
APPENDIX H

PEARSON'S CORRELATIONS FOR LANDSCAPE INDICES 


\begin{tabular}{|c|c|c|c|c|c|c|}
\hline & $A_{8}$ & Const & For & Ind & Mit & Mew \\
\hline Const & -0.505 & & & & & \\
\hline For & 0.144 & -0.057 & & & & \\
\hline Ind & -0.186 & 0.531 & -0.223 & & & \\
\hline Mit & 0.207 & -0.268 & -0.374 & 0.083 & & \\
\hline Mow & -0.535 & 0.167 & -0.567 & 0.219 & -0.390 & \\
\hline Old & -0.173 & -0.299 & -0.572 & 0.041 & 0.423 & 0.286 \\
\hline Park & -0.128 & 0.187 & -0.172 & -0.112 & 0.104 & -0.166 \\
\hline Pond & 0.250 & -0.278 & -0.453 & 0.193 & 0.961 & -0.350 \\
\hline Res & 0.025 & 0.002 & 0.125 & -0.249 & 0.103 & -0.285 \\
\hline Road & -0.286 & 0.075 & -0.590 & 0.063 & -0.176 & 0.855 \\
\hline Wway & 0.421 & 0.185 & 0.180 & 0.002 & -0.363 & -0.272 \\
\hline \multirow[t]{2}{*}{ Wet } & 0.010 & -0.446 & 0.102 & -0.359 & 0.043 & -0.041 \\
\hline & Old & Put & Pond & $\mathrm{Res}$ & $\operatorname{Ros}$ & $\nabla \omega y$ \\
\hline Park & 0.392 & & & & & \\
\hline Pond & 0.467 & 0.158 & & & & \\
\hline Res & -0.608 & -0.315 & 0.104 & & & \\
\hline Road & 0.164 & -0.258 & -0.234 & -0.231 & & \\
\hline Wway & -0.112 & 0.594 & -0.254 & -0.336 & -0.330 & \\
\hline Wet & 0.543 & -0.088 & 0.019 & -0.313 & -0.201 & -0.166 \\
\hline
\end{tabular}

Table H.1 Pearson's correlations (r) for $300 \mathrm{~m}$ land use percentages. 


\begin{tabular}{|c|c|c|c|c|c|c|}
\hline & $\mathrm{Ag}$ & Const & For & nd & Min & Mow \\
\hline Const & -0.395 & & & & & \\
\hline For & 0.172 & -0.377 & & & & \\
\hline Ind & -0.430 & 0.749 & -0.854 & & & \\
\hline Mitig & 0.524 & -0.382 & 0.051 & -0.254 & & \\
\hline Mow & -0.522 & 0.207 & 0.231 & 0.072 & -0.568 & \\
\hline Oldf & 0.253 & 0.348 & 0.034 & 0.146 & 0.175 & 0.172 \\
\hline Park & 0.169 & 0.213 & -0.476 & 0.400 & 0.633 & -0.612 \\
\hline Pond & 0.760 & -0.044 & 0.114 & -0.109 & 0.643 & -0.281 \\
\hline Res & 0.117 & -0.721 & 0.011 & -0.418 & 0.117 & -0.385 \\
\hline Rd & -0.564 & -0.055 & -0.673 & 0.505 & -0.190 & 0.110 \\
\hline Water & 0.083 & 0.404 & 0.156 & 0.044 & -0.125 & -0.193 \\
\hline \multirow[t]{2}{*}{ Wet } & -0.172 & -0.171 & 0.563 & -0.514 & -0.048 & 0.113 \\
\hline & Oldi & Par & Poud & $\mathrm{Res}_{\mathrm{s}}$ & Rd & $W$ \\
\hline Park & 0.005 & & & & & \\
\hline Pond & 0.511 & 0.448 & & & & \\
\hline Res & -0.842 & -0.033 & -0.348 & & & \\
\hline Rd & -0.395 & 0.010 & -0.599 & 0.349 & & \\
\hline Water & 0.552 & 0.068 & 0.146 & -0.561 & -0.541 & \\
\hline Wet & 0.247 & -0.359 & -0.319 & -0.086 & -0.283 & 0.505 \\
\hline
\end{tabular}

$\mathbf{A g}=$ Agriculture, Const $=$ Construction, For $=$ Forest, Ind $=$ Industrial, Mit $=$ Mitigation wetland Mow $=$ Mowed grass, Old $=$ Oldfield, Res $=$ Residential, Wway $=$ Waterway, Wet $=$ Wetland

Table H.2 Pearson's correlations (r) for $1000 \mathrm{~m}$ land use percentages. 


\begin{tabular}{|c|c|c|c|c|c|c|}
\hline Construction & \%Land & \#Patch & Density & Area & Gyrate & Proxim \\
\hline \#Patch & 0.153 & & & & & \\
\hline Density & 0.259 & 0.945 & & & & \\
\hline Area & 0.858 & -0.290 & -0.248 & & & \\
\hline Gyrate & 0.659 & -0.236 & -0.302 & 0.893 & & \\
\hline Proxim & 0.242 & 0.841 & 0.912 & -0.187 & -0.209 & \\
\hline IJI & 0.798 & 0.702 & 0.741 & 0.443 & 0.345 & 0.689 \\
\hline Forest & KLand & \#Patch & Density & Area & Gyrate & Proxim \\
\hline \#Patch & 0.474 & & & & & \\
\hline Density & 0.375 & 0.976 & & & & \\
\hline Area & 0.590 & -0.356 & -0.448 & & & \\
\hline Gyrate & 0.434 & -0.459 & -0.545 & 0.938 & & \\
\hline Proxim & 0.882 & 0.333 & 0.245 & 0.576 & 0.402 & \\
\hline IJI & 0.827 & 0.425 & 0.391 & 0.429 & 0.303 & 0.785 \\
\hline Induatrial & \%land & \#Patch & Density & Area & Gyrate & Proxim \\
\hline \#Patch & 0.854 & & & & & \\
\hline Density & 0.736 & 0.979 & & & & \\
\hline Area & 0.322 & -0.206 & -0.376 & & & \\
\hline Gyrate & 0.341 & -0.178 & -0.341 & 0.920 & & \\
\hline Proxim & 0.946 & 0.969 & 0.899 & 0.001 & 0.038 & \\
\hline IJI & 0.620 & 0.185 & -0.018 & 0.742 & 0.768 & 0.420 \\
\hline Mitiontion & $\%$ Land & \#Patch & Density & Area & Gyrate & Proxim \\
\hline \#Patch & -0.339 & & & & & \\
\hline Density & -0.457 & 0.974 & & & & \\
\hline Area & 0.986 & -0.471 & -0.586 & & & \\
\hline Gyrate & 0.752 & -0.687 & -0.823 & 0.835 & & \\
\hline Proxim & -0.366 & 0.463 & 0.576 & -0.417 & -0.600 & \\
\hline IJI & 0.429 & -0.445 & -0.504 & 0.430 & 0.497 & -0.604 \\
\hline Mowed & \%Land & \#Patch & Density & Area & Gyrate & Proxim \\
\hline \#Patch & 0.256 & & & & & \\
\hline Density & 0.269 & 0.973 & & & & \\
\hline Area & 0.798 & -0.290 & -0.293 & & & \\
\hline Gyrate & 0.815 & -0.104 & -0.165 & 0.871 & & \\
\hline
\end{tabular}

$\%$ Land = percent of landscape, \#Patch = number of patches, Density = patch density (\#/100 ha)

Area $=$ area of landscape, Gyrate $=$ radius of gyration, proxim $=$ proximity index

Continued

Table H.3 Pearson's correlations (r) for $300 \mathrm{~m}$ landscape metrics by land use class. 
Table H. 3 continued

\begin{tabular}{|c|c|c|c|c|c|c|}
\hline Mowed (contd) & \%Land & \#Patch & Density & Area & Gyrate & Proxim \\
\hline Proxim & 0.744 & 0.564 & 0.532 & 0.306 & 0.514 & \\
\hline IJI & 0.674 & 0.556 & 0.567 & 0.463 & 0.443 & 0.592 \\
\hline Oldfield & \%Lland & \#Patch & Density & Area & Gyrate & Proxim \\
\hline \#Patch & 0.533 & & & & & \\
\hline Density & 0.456 & 0.976 & & & & \\
\hline Area & 0.684 & -0.178 & -0.255 & & & \\
\hline Gyrate & 0.708 & -0.057 & -0.159 & 0.931 & & \\
\hline Proxim & 0.731 & 0.604 & 0.517 & 0.272 & 0.410 & \\
\hline IJI & 0.742 & 0.198 & 0.114 & 0.731 & 0.830 & 0.271 \\
\hline Part & \%Land & \#Patch & Density & Area & Gyrate & Proxim \\
\hline \#Patch & 0.994 & & & & & \\
\hline Density & 0.993 & 1.000 & & & & \\
\hline Area & -0.796 & -0.859 & -0.862 & & & \\
\hline Gyrate & -0.007 & -0.12 & -0.125 & 0.611 & & \\
\hline Proxim & 0.994 & 1.000 & 1.000 & -0.859 & -0.120 & \\
\hline IJI & 0.967 & 0.932 & 0.930 & -0.615 & 0.249 & 0.932 \\
\hline Pond & \%Land & \#Patch & Density & Area & Gyrate & Proxim \\
\hline \#Patch & 0.997 & & & & & \\
\hline Density & 0.997 & 1.000 & & & & \\
\hline Area & 0.989 & 0.993 & 0.989 & & & \\
\hline Gyrate & 0.959 & 0.969 & 0.962 & 0.991 & & \\
\hline Proxim & 0.999 & 0.992 & 0.993 & 0.982 & 0.947 & \\
\hline IJI & 0.699 & 0.728 & 0.711 & 0.774 & 0.831 & 0.676 \\
\hline Reaideatin & $\%$ Land & \#Patch & Density & Area & Gyrate & Proxim \\
\hline \#Patch & 0.506 & & & & & \\
\hline Density & 0.503 & 0.988 & & & & \\
\hline Area & 0.737 & -0.089 & -0.123 & & & \\
\hline Gyrate & 0.342 & -0.194 & -0.256 & 0.785 & & \\
\hline Proxim & 0.882 & 0.069 & 0.089 & 0.881 & 0.454 & \\
\hline III & -0.211 & -0.119 & -0.049 & -0.094 & -0.123 & -0.015 \\
\hline
\end{tabular}

Continued 
Table H.3 continued

\begin{tabular}{|c|c|c|c|c|c|c|}
\hline Rood & $\%$ Land & \#Patch & Density & Area & Gyrate & Proxim \\
\hline \#Patch & 0.643 & & & & & \\
\hline Density & 0.577 & 0.959 & & & & \\
\hline Area & 0.856 & 0.270 & 0.201 & & & \\
\hline Gyrate & -0.387 & -0.741 & -0.854 & 0.058 & & \\
\hline Proxim & 0.966 & 0.500 & 0.456 & 0.817 & -0.364 & \\
\hline IJI & 0.282 & 0.400 & 0.520 & 0.163 & -0.523 & 0.239 \\
\hline Waterway & $\%$ and & \#Patch & Density & Area & Gyrate & Proxim \\
\hline \#Patch & 0.702 & & & & & \\
\hline Density & 0.710 & 0.997 & & & & \\
\hline Area & 0.625 & -0.111 & -0.106 & & & \\
\hline Gyrate & 0.363 & -0.260 & -0.239 & 0.770 & & \\
\hline Proxim & 0.702 & 1.000 & 0.997 & -0.111 & -0.260 & \\
\hline ІЛI & 0.351 & 0.630 & 0.632 & -0.205 & 0.187 & 0.630 \\
\hline Wetlingd & \%Land & \#Patch & Density & Area & Gyrate & Proxim \\
\hline \#Patch & 0.935 & & & & & \\
\hline Density & 0.968 & 0.990 & & & & \\
\hline Area & 0.663 & 0.489 & 0.523 & & & \\
\hline Gyrate & 0.019 & -0.013 & -0.034 & 0.678 & & \\
\hline Proxim & 0.969 & 0.955 & 0.985 & 0.482 & -0.140 & \\
\hline IJI & 0.617 & 0.507 & 0.547 & 0.410 & -0.053 & 0.542 \\
\hline
\end{tabular}

\%Land = percent of landscape, \#Patch = number of patches, Density = patch density (\#/100 ha)

Area $=$ area of landscape, Gyrate $=$ radius of gyration, proxim $=$ proximity index 
APPENDIX I

PEARSON'S CORRELATIONS FOR LANDSCAPE AREA 


\begin{tabular}{|c|c|c|c|}
\hline \multicolumn{2}{|c|}{300 m Patch Density } & \multicolumn{2}{|c|}{1000 in Patel Denaity } \\
\hline & Landscape Area & & Landscape Area \\
\hline Patch Density & -0.248 & Patch Density & 0.536 \\
\hline \multicolumn{2}{|c|}{300 m Land Use Pereentages } & \multicolumn{2}{|c|}{$1060 \mathrm{~m}$ Land Use Pereenthes } \\
\hline & Landscape Area & & Landacepe Area \\
\hline $\mathrm{Ag}$ & 0.403 & $\mathbf{A g}$ & 0.407 \\
\hline Const & -0.413 & Const & -0.800 \\
\hline For & 0.021 & For & 0.163 \\
\hline Ind & -0.182 & Ind & -0.530 \\
\hline Mit & 0.614 & Mit & 0.635 \\
\hline Mow & -0.336 & Mow & -0.518 \\
\hline Old & -0.193 & Old & -0.429 \\
\hline Park & -0.525 & Park & 0.110 \\
\hline Pond & 0.467 & Pond & 0.131 \\
\hline Res & 0.375 & Res & 0.729 \\
\hline Road & 0.086 & Road & 0.143 \\
\hline Wway & -0.551 & Wway & -0.530 \\
\hline Wet & -0.110 & Wet & -0.102 \\
\hline \multicolumn{2}{|c|}{300 a Combined Land Uses } & \multicolumn{2}{|c|}{100 m Combined Land Uses } \\
\hline \multicolumn{2}{|c|}{ Landscene Area } & \multicolumn{2}{|c|}{ Landocepe Area } \\
\hline Human \%land & 0.416 & Human Yland & 0.149 \\
\hline Natural \%land & -0.514 & Natural \%land & -0.123 \\
\hline Water \%land & 0.108 & Water \%land & -0.229 \\
\hline
\end{tabular}

300 m Amphibian Metries

Landecipe Area

\begin{tabular}{lc}
\hline Forest \%land & 0.015 \\
Wetland \%land & -0.117 \\
Road \%land & 0.087 \\
Urban \%land & 0.313 \\
Forest Gyrate & 0.635 \\
Road Gyrate & 0.383 \\
\hline
\end{tabular}

$\mathrm{Ag}=$ Agriculture, Const $=$ Construction, For $=$ Forest Ind $=$ Industrial, Mit $=$ Mitigation wetland Mow $=$ Mowed grass, Old $=$ Oldfield, Res $=$ Residential, $\mathbf{W}$ way $=$ Waterway, Wet $=$ Wetland $\%$ Land = percent of landscape, Patch Density = \# patches/100 ha

Table I.1 Pearson's correlations (r) for landscape sizes (ha) and all landscape metrics. 
APPENDIX J

PERMIT COMPLIANCE DATA 
Projects that created or restored mitigation wetlands independently

\begin{tabular}{ccccccccc} 
Project \# & Imp & Req & Mit & Compliance & Net Gain & CRW Impacts & CRW Mit & Exp Mit \\
\hline 1 & 1.44 & 1.45 & 1.37 & -0.08 & -0.07 & 1.44 & 1.37 & 0.00 \\
2 & 0.57 & 2.02 & 1.03 & -0.99 & 0.47 & 0.57 & 1.03 & 0.00 \\
3 & 0.56 & 0.93 & 1.42 & 0.49 & 0.86 & 0.56 & 1.42 & 0.00 \\
4 & 0.37 & 0.81 & 1.67 & 0.86 & 1.30 & 0.37 & 1.67 & 0.00 \\
5 & 4.98 & 10.12 & 8.63 & -1.49 & 3.65 & 4.98 & 0.00 & 8.63 \\
6 & 0.43 & 0.43 & 0.77 & 0.34 & 0.34 & 0.43 & 0.77 & 0.00 \\
7 & 0.50 & 1.63 & 2.44 & 0.81 & 1.94 & 0.50 & 2.44 & 0.00 \\
8 & 0.89 & 1.75 & 0.77 & -0.98 & -0.12 & 0.89 & 0.77 & 0.00 \\
9 & 0.07 & 0.13 & 0.11 & -0.03 & 0.04 & 0.07 & 0.11 & 0.00 \\
10 & 0.02 & 0.51 & 0.28 & -0.23 & 0.25 & 0.02 & 0.28 & 0.00 \\
11 & 0.23 & 0.42 & 0.24 & -0.17 & 0.01 & 0.23 & 0.24 & 0.00 \\
12 & 0.96 & 1.57 & $1.520 *$ & -0.05 & 0.57 & 0.59 & 0.48 & 1.04 \\
Subtotal & 11.02 & 21.77 & 20.26 & -1.51 & 9.24 & 10.65 & 10.59 & 9.67 \\
\hline Projects that purchased mitigation bank credits or preserved wetlands for mitigation & & \\
Project \# & Imp & Req & Mit & Compliance & Net Gain & CRW Impacts & CRW Mit & Exp Mit \\
\hline 13 & 0.16 & 0.35 & 0.35 & 0.00 & 0.19 & 0.16 & 0.00 & 0.35 \\
14 & 0.05 & 0.12 & 0.12 & 0.00 & 0.07 & 0.05 & 0.00 & 0.12 \\
15 & 0.08 & 0.15 & 0.15 & 0.00 & 0.08 & 0.08 & 0.00 & 0.15 \\
16 & 0.27 & 0.00 & 0.00 & 0.00 & -0.27 & 0.27 & 0.00 & 0.00 \\
17 & 0.23 & 0.45 & 0.45 & 0.00 & 0.22 & 0.23 & 0.00 & 0.45 \\
18 & 0.99 & 1.54 & 1.54 & 0.00 & 0.55 & 0.99 & 0.00 & 1.54 \\
19 & 0.17 & 0.32 & 0.32 & 0.00 & 0.16 & 0.17 & 0.00 & 0.32 \\
20 & 0.17 & 0.28 & 0.28 & 0.00 & 0.11 & 0.17 & 0.00 & 0.28 \\
21 & 0.36 & 0.00 & 0.00 & 0.00 & -0.36 & 0.36 & 0.00 & 0.00 \\
22 & 1.08 & 2.02 & 2.02 & 0.00 & 0.94 & 1.08 & 0.00 & 2.02 \\
23 & 0.37 & 0.77 & 0.77 & 0.00 & 0.40 & 0.37 & 0.77 & 0.00 \\
Subtotal & $\mathbf{3 . 9 3}$ & $\mathbf{6 . 0 1}$ & $\mathbf{6 . 0 1}$ & $\mathbf{0 . 0 0}$ & 2.08 & 3.93 & $\mathbf{0 . 7 7}$ & $\mathbf{5 . 2 4}$ \\
TOTAL & 14.95 & 27.78 & 26.27 & -1.51 & 11.31 & 1458 & 11.36 & 14.91 \\
\hline
\end{tabular}

Imp = area (ha) of impacted wetlands, $R$ eq $=$ area (ha) of required mitigation

Mit = area (ha) of constructed mitigation, Compliance $=$ deviation (ha) from required mitigation area

Net Gain = gain or loss of wetland area

CRW Impacts = area (ha) of impacts that occurred in the Cuyahoga River watershed

CRW Mit = area (ha) of mitigation that was constructed in the Cuyahoga River watershed

Exp Mit = area (ha) of mitigation that was exported from the Cuyahoga River watershed

Table J.1 Data for wetland impacts and mitigation used for calculation of permit compliance and net gain/loss of wetland area. 
APPENDIX K

WETLAND STRUCTURE DATA 


\begin{tabular}{clcccccc}
\hline Project \# & Project Name & $\begin{array}{c}\text { Impacts } \\
\text { Emerg/OW }\end{array}$ & $\begin{array}{c}\text { Impacts } \\
\text { Forested }\end{array}$ & $\begin{array}{c}\text { Impacts } \\
\text { Scrub/Shrub }\end{array}$ & $\begin{array}{c}\text { Mitigation } \\
\text { Emerg/OW }\end{array}$ & $\begin{array}{c}\text { Mitigation } \\
\text { Forested }\end{array}$ & $\begin{array}{c}\text { Mitigation } \\
\text { Scrub/Shrub }\end{array}$ \\
\hline 1 & I-80 Bridges & 1.13 & 0.31 & 0.00 & 1.37 & 0.00 & 0.00 \\
2 & Four Seasons & 0.00 & 0.57 & 0.00 & 0.93 & 0.05 & 0.05 \\
3 & Harvard Road & 0.29 & 0.10 & 0.17 & 1.42 & 0.00 & 0.00 \\
4 & Kerruish & 0.00 & 0.00 & 0.37 & 1.59 & 0.00 & 0.08 \\
5 & Lombardo & 1.58 & 0.31 & 3.10 & 5.78 & 0.00 & 2.85 \\
6 & OTC & 0.12 & 0.13 & 0.18 & 0.62 & 0.15 & 0.00 \\
7 & Twinsburg & 0.30 & 0.20 & 0.00 & 2.44 & 0.00 & 0.00 \\
8 & Whitlach & 0.74 & 0.15 & 0.00 & 0.77 & 0.00 & 0.00 \\
9 & Admore Drive & 0.07 & 0.00 & 0.00 & 0.11 & 0.00 & 0.00 \\
10 & Kent State & 0.02 & 0.00 & 0.00 & 0.28 & 0.00 & 0.00 \\
11 & Rapids Road & 0.00 & 0.00 & 0.23 & 0.24 & 0.00 & 0.00 \\
12 & Geauga Lake & 0.44 & 0.05 & 0.47 & 1.22 & 0.30 & 0.00 \\
TOTAL & & 4.63 & 1.82 & 4.52 & 16.77 & 0.51 & 2.98 \\
\hline
\end{tabular}

All vegetation areas are in hectares (ha)

Emerg/OW = Emergent and open water

Table K.1 Area of vegetation types for wetland impacts and mitigation for all projects that created or restored mitigation wetlands independently. 


\begin{tabular}{|c|c|c|c|c|c|}
\hline Project \# & Project Name & Wetland Size (ha) & Project \# & Project Name & Wetland Size (ha) \\
\hline 1 & I-80 Bridges & 0.048 & 5 & Lombardo & 0.478 \\
\hline 1 & I-80 Bridges & 0.045 & 5 & Lombardo & 4.504 \\
\hline 1 & I-80 Bridges & 0.013 & 6 & OTC & 0.004 \\
\hline 1 & I-80 Bridges & 0.062 & 6 & OTC & 0.012 \\
\hline 1 & I-80 Bridges & 0.160 & 6 & OTC & 0.016 \\
\hline 1 & I-80 Bridges & 0.417 & 6 & OTC & 0.016 \\
\hline 1 & I-80 Bridges & 0.504 & 6 & OTC & 0.004 \\
\hline 1 & I-80 Bridges & 0.013 & 6 & OTC & 0.004 \\
\hline 1 & I-80 Bridges & 0.002 & 6 & OTC & 0.016 \\
\hline 1 & I-80 Bridges & 0.012 & 6 & OTC & 0.008 \\
\hline 1 & I-80 Bridges & 0.002 & 6 & OTC & 0.004 \\
\hline 1 & I-80 Bridges & 0.003 & 6 & OTC & 0.073 \\
\hline 1 & I-80 Bridges & 0.049 & 6 & OTC & 0.174 \\
\hline 1 & I-80 Bridges & 0.007 & 6 & OTC & 0.057 \\
\hline 1 & I-80 Bridges & 0.016 & 6 & OTC & 0.032 \\
\hline 1 & I-80 Bridges & 0.013 & 6 & OTC & 0.012 \\
\hline 1 & I-80 Bridges & 0.008 & 7 & Twinsburg & 0.235 \\
\hline 1 & I-80 Bridges & 0.062 & 7 & Twinsburg & 0.008 \\
\hline 2 & Four Seasons & 0.033 & 7 & Twinsburg & 0.154 \\
\hline 2 & Four Seasons & 0.025 & 7 & Twinsburg & 0.040 \\
\hline 2 & Four Seasons & 0.135 & 7 & Twinsburg & 0.061 \\
\hline 2 & Four Seasons & 0.038 & 8 & Whitlach & 0.016 \\
\hline 2 & Four Seasons & 0.197 & 8 & Whitlach & 0.004 \\
\hline 2 & Four Seasons & 0.062 & 8 & Whitlach & 0.004 \\
\hline 2 & Four Seasons & 0.076 & 8 & Whitlach & 0.020 \\
\hline 3 & Harvard Road & 0.028 & 8 & Whitlach & 0.016 \\
\hline 3 & Harvard Road & 0.049 & 8 & Whitlach & 0.036 \\
\hline 3 & Harvard Road & 0.016 & 8 & Whitlach & 0.040 \\
\hline 3 & Harvard Road & 0.045 & 8 & Whitlach & 0.008 \\
\hline 3 & Harvard Road & 0.125 & 8 & Whitlach & 0.745 \\
\hline 3 & Harvard Road & 0.065 & 9 & Admore Drive & 0.069 \\
\hline 3 & Harvard Road & 0.036 & 10 & Kent State & 0.024 \\
\hline 3 & Harvard Road & 0.008 & 11 & Rapids Road & 0.008 \\
\hline 3 & Harvard Road & 0.036 & 11 & Rapids Road & 0.004 \\
\hline 3 & Harvard Road & 0.049 & 11 & Rapids Road & 0.004 \\
\hline 3 & Harvard Road & 0.012 & 11 & Rapids Road & 0.008 \\
\hline 3 & Harvard Road & 0.093 & 11 & Rapids Road & 0.206 \\
\hline 4 & Kerruish & 0.028 & & & \\
\hline 4 & Kernuish & 0.037 & & & \\
\hline 4 & Kernuish & 0.089 & & & \\
\hline 4 & Kerruish & 0.216 & & & \\
\hline
\end{tabular}

Continued

Table K.2 Size (ha) of impacted wetlands. 
Table K.2 continued

\begin{tabular}{|c|c|c|c|c|c|}
\hline Project \# & Project Name & Wetland Size (ha) & Project \# & Project Nane & Wetland Sire (ha) \\
\hline 12 & Geauga Lake & 0.138 & 18 & North Point & 0.397 \\
\hline 12 & Geauga Lake & 0.024 & 18 & North Point & 0.255 \\
\hline 12 & Geauga Lake & 0.012 & 18 & North Point & 0.186 \\
\hline 12 & Geauga Lake & 0.045 & 18 & North Point & 0.036 \\
\hline 12 & Geauga Lake & 0.190 & 18 & North Point & 0.057 \\
\hline 12 & Geauga Lake & 0.546 & 18 & North Point & 0.061 \\
\hline 13 & Whisp Meadows & 0.008 & 19 & Cameratta & 0.020 \\
\hline 13 & Whisp Meadows & 0.015 & 19 & Cameratta & 0.057 \\
\hline 13 & Whisp Meadows & 0.063 & 19 & Cameratta & 0.089 \\
\hline 13 & Whisp Meadows & 0.005 & 20 & GOJO & 0.174 \\
\hline 13 & Whisp Meadows & 0.001 & 21 & Hudson Industrial & 0.049 \\
\hline 13 & Whisp Meadows & 0.006 & 21 & Hudson Industrial & 0.017 \\
\hline 13 & Whisp Meadows & 0.006 & 21 & Hudson Industrial & 0.007 \\
\hline 13 & Whisp Meadows & 0.011 & 21 & Hudson Industrial & 0.275 \\
\hline 13 & Whisp Meadows & 0.002 & 21 & Hudson Industrial & 0.001 \\
\hline 13 & Whisp Meadows & 0.003 & 21 & Hudson Industrial & 0.002 \\
\hline 13 & Whisp Meadows & 0.018 & 21 & Hudson Industrial & 0.007 \\
\hline 13 & Whisp Meadows & 0.004 & 21 & Hudson Industrial & 0.004 \\
\hline 13 & Whisp Meadows & 0.019 & 22 & Seabreeze & 0.252 \\
\hline 14 & Dayton Freight & 0.049 & 22 & Seabreeze & 0.072 \\
\hline 15 & Nesbitt Road & 0.036 & 22 & Seabreeze & 0.760 \\
\hline 15 & Nesbitt Road & 0.012 & 23 & Wilcox & 0.012 \\
\hline 15 & Nesbitt Road & 0.028 & 23 & Wilcox & 0.004 \\
\hline 16 & Ambina Road & 0.170 & 23 & Wilcox & 0.069 \\
\hline 16 & Ambina Road & 0.093 & 23 & Wilcox & 0.053 \\
\hline 16 & Ambina Road & 0.008 & 23 & Wilcox & 0.008 \\
\hline 17 & Old River Bed & 0.154 & 23 & Wilcox & 0.223 \\
\hline 17 & Old River Bed & 0.020 & & & \\
\hline 17 & Old River Bed & 0.053 & & & \\
\hline
\end{tabular}




\begin{tabular}{|c|c|c|c|c|c|}
\hline Project \# & Project Na & Area (ha) & Project \# & Project $\mathrm{Na}$ & Area (ha) \\
\hline 1 & I-80 Bridges & 0.180 & 12 & Geauga Lake & 0.188 \\
\hline 1 & I-80 Bridges & 1.192 & 12 & Geauga Lake & 1.033 \\
\hline 2 & Four Seasons & 0.509 & 12 & Geauga Lake & 0.001 \\
\hline 2 & Four Seasons & 0.525 & 12 & Geauga Lake & 0.002 \\
\hline 3 & Harvard Road & 1.424 & 12 & Geauga Lake & 0.004 \\
\hline 4 & Kerruish & 1.671 & 12 & Geauga Lake & 0.005 \\
\hline 5 & Lombardo & 0.020 & 12 & Geauga Lake & 0.005 \\
\hline 5 & Lombardo & 0.060 & 12 & Geauga Lake & 0.005 \\
\hline 5 & Lombardo & 0.061 & 12 & Geauga Lake & 0.005 \\
\hline 5 & Lombardo & 0.092 & 12 & Geauga Lake & 0.005 \\
\hline 5 & Lombardo & 1.258 & 12 & Geauga Lake & 0.006 \\
\hline 5 & Lombardo & 7.136 & 12 & Geauga Lake & 0.007 \\
\hline 6 & OTC & 0.771 & 12 & Geauga Lake & 0.008 \\
\hline 7 & Twinsburg & 2.440 & 12 & Geauga Lake & 0.009 \\
\hline 8 & Whitlach & 0.134 & 12 & Geauga Lake & 0.010 \\
\hline 8 & Whitlach & 0.637 & 12 & Geauga Lake & 0.010 \\
\hline 9 & Admore Drive & 0.108 & 12 & Geauga Lake & 0.011 \\
\hline 10 & Rapids Road & 0.025 & 12 & Geauga Lake & 0.011 \\
\hline 10 & Rapids Road & 0.209 & 12 & Geauga Lake & 0.012 \\
\hline 10 & Rapids Road & 0.009 & 12 & Geauga Lake & 0.012 \\
\hline 11 & Kent State & 0.009 & 12 & Geauga Lake & 0.014 \\
\hline 11 & Kent State & 0.011 & 12 & Geauga Lake & 0.018 \\
\hline 11 & Kent State & 0.011 & 12 & Geauga Lake & 0.021 \\
\hline 11 & Kent State & 0.012 & 12 & Geauga Lake & 0.021 \\
\hline 11 & Kent State & 0.015 & 12 & Geauga Lake & 0.097 \\
\hline 11 & Kent State & 0.016 & 13 & Whisp Meadows & 0.348 \\
\hline 11 & Kent State & 0.018 & 14 & Dayton Freight & 0.121 \\
\hline 11 & Kent State & 0.020 & 15 & Nesbitt Road & 0.154 \\
\hline 11 & Kent State & 0.021 & 16 & Ambina Road & $0.000^{*}$ \\
\hline 11 & Kent State & 0.023 & 17 & Old River Bed & 0.445 \\
\hline \multirow[t]{6}{*}{11} & Kent State & 0.121 & 18 & North Point & 1.538 \\
\hline & & & 19 & Cameratta & 0.324 \\
\hline & & & 20 & GOJO & 0.283 \\
\hline & & & 21 & Hudson Industrial & $0.000^{*}$ \\
\hline & & & 22 & Seabreeze & 2.024 \\
\hline & & & 23 & Wilcox & 0.769 \\
\hline
\end{tabular}

* Impacts were mitigated entirely through wetland preservation; no wetlands were created or restored for mitigation

Table K.3 Size (ha) of mitigation wetlands. 


\begin{tabular}{clcc}
\hline Project \# & Project Name & \# Impacted Wetlands & \# Mitigation Wetlands \\
\hline 1 & I-80 Bridges & 18 & 2 \\
2 & Four Seasons & 7 & 2 \\
3 & Harvard Road & 12 & 1 \\
4 & Kerruish & 4 & 1 \\
5 & Lombardo & 2 & 6 \\
6 & OTC & 14 & 1 \\
7 & Twinsburg & 5 & 1 \\
8 & Whitlach & 9 & 2 \\
9 & Admore Drive & 1 & 1 \\
10 & Kent State & 1 & 11 \\
11 & Rapids Road & 5 & 3 \\
12 & Geauga Lake & 6 & 25 \\
13 & Whisp Meadows & 13 & 1 \\
14 & Dayton Freight & 1 & 1 \\
15 & Nesbitt Road & 3 & 1 \\
16 & Ambina Road & 3 & $0 *$ \\
17 & Old River Bed & 3 & 1 \\
18 & North Point & 6 & 1 \\
19 & Cameratta & 3 & 1 \\
20 & GOJO & 1 & 1 \\
21 & Hudson Industrial & 8 & $0 *$ \\
22 & Seabreeze & 3 & 1 \\
23 & Wilcox & 6 & 1 \\
TOTAL & & 134 & 65 \\
\hline
\end{tabular}

* Impacts were mitigated entirely through wetland preservation; no wetlands were created or restored for mitigation

Table K.4 Number of impacted and mitigation wetlands for each project. 
APPENDIX L

LANDSCAPE DATA 


\begin{tabular}{|c|c|c|c|c|c|c|}
\hline \multicolumn{7}{|c|}{ Project \#I (I-80 Bridges) } \\
\hline Land Use & \# Patches & PD & $\mathbf{C A}$ & Gyrate & Proxim & IJI \\
\hline $\mathbf{A g}$ & NA & NA & NA & NA & NA & NA \\
\hline Const & 1 & 1.53 & 0.93 & 51.3 & 0.0 & 37.9 \\
\hline For & 6 & 9.18 & 3.01 & 65.7 & 276.0 & 77.8 \\
\hline Ind & NA & NA & NA & NA & NA & NA \\
\hline Mit & 2 & 3.06 & 0.68 & 35.5 & 7.3 & 63.9 \\
\hline Mow & 2 & 3.06 & 2.32 & 75.6 & 0.6 & 80.5 \\
\hline Old & 11 & 16.84 & 1.45 & 52.4 & 348.4 & 65.4 \\
\hline Park & NA & NA & NA & NA & NA & NA \\
\hline Pond & NA & NA & NA & NA & NA & NA \\
\hline Res & 1 & 1.53 & 0.80 & 36.0 & 0.0 & 54.4 \\
\hline Road & 1 & 1.53 & 2.88 & 234.9 & 0.0 & 56.5 \\
\hline Wway & NA & NA & NA & NA & NA & NA \\
\hline Wet & 8 & 1225 & 0.67 & 27.8 & 23.4 & 65.7 \\
\hline \multicolumn{7}{|c|}{ Project \#2 (Four Seasons) } \\
\hline Land Use & \# Patches & PD & CA & Gyrate & Proxim & II \\
\hline $\mathrm{Ag}$ & NA & NA & NA & NA & NA & NA \\
\hline Const & 4 & 5.73 & 0.55 & 52.8 & 51.8 & 60.9 \\
\hline For & 10 & 14.34 & 1.85 & 59.6 & 100.9 & 60.1 \\
\hline Ind & NA & NA & NA & NA & NA & NA \\
\hline Mit & 2 & 2.87 & 0.52 & 42.1 & 3.3 & 30.9 \\
\hline Mow & 10 & 14.34 & 0.43 & 42.9 & 30.3 & 67.0 \\
\hline Old & 3 & 4.30 & 0.24 & 19.7 & 0.0 & 45.0 \\
\hline Park & NA & NA & NA & NA & NA & NA \\
\hline Pond & 1 & 1.43 & 0.07 & 10.8 & 0.0 & 0.0 \\
\hline Res & 7 & 10.03 & 3.58 & 76.6 & 19612 & 51.6 \\
\hline Road & 1 & 1.43 & 2.36 & 261.0 & 0.0 & 39.6 \\
\hline Wway & NA & NA & NA & NA & NA & NA \\
\hline Wet & 1 & 1.43 & 0.16 & 15.8 & 0.0 & 32.4 \\
\hline
\end{tabular}

$\mathrm{Ag}=$ Agriculture, Const $=$ Construction, For $=$ Forest Ind $=$ Industrial, Mit $=$ Mitigation wetland Mow $=$ Mowed grass, Old $=$ Oldfield, Res $=$ Residential, Wway $=$ Waterway, Wet $=$ Wetland \# Patches = number of patches in the landscape, $\mathrm{PD}=$ patch density (\# patches/100 ha)

$\mathrm{CA}=$ mean patch area $\left(\mathrm{m}^{2}\right)$ for land use, Gyrate $=$ radius of gyration $(\mathrm{m})$

Proxim = proximity index (unitless), $\mathrm{IJI}=$ interspersion and juxtaposition index (\%)

Continued

Table L.1 Landscape data for $300 \mathrm{~m}$ landscapes. 


\begin{tabular}{|c|c|c|c|c|c|c|}
\hline \multicolumn{7}{|c|}{ Project \#3 (Harvard Road) } \\
\hline Land Use & \# Putelos & PD & $\mathbf{C A}$ & Gyrate & Proxin & $\mathbf{U}$ \\
\hline $\mathrm{Ag}$ & NA & NA & NA & NA & NA & NA \\
\hline Const & 3 & 4.14 & 0.80 & 55.6 & 0.0 & 53.8 \\
\hline For & 3 & 4.14 & 1.43 & 48.3 & 18.7 & 45.7 \\
\hline Ind & 2 & 2.76 & 1.32 & 53.8 & 0.3 & 57.1 \\
\hline Mit & 1 & 1.38 & 1.45 & 83.8 & 0.0 & 34.6 \\
\hline Mow & 4 & 5.52 & 2.72 & 122.5 & 72.4 & 73.3 \\
\hline Old & 6 & 8.28 & 2.26 & 55.2 & 10.0 & 87.3 \\
\hline Park & NA & NA & NA & NA & NA & NA \\
\hline Pond & NA & NA & NA & NA & NA & NA \\
\hline Res & NA & NA & NA & NA & NA & NA \\
\hline Road & 4 & 5.52 & 4.80 & 111.4 & 1001.3 & 61.6 \\
\hline Wway & NA & NA & NA & NA & NA & NA \\
\hline Wet & NA & NA & NA & NA & NA & NA \\
\hline \multicolumn{7}{|c|}{ Project \#4 (Kerruish) } \\
\hline Land Use & \#Prtehes & PD & $\mathbf{C A}$ & Gyrate & Proxim & III \\
\hline $\mathrm{Ag}$ & NA & NA & NA & NA & NA & NA \\
\hline Const & 2 & 2.55 & 4.05 & 115.3 & 12.3 & 64.1 \\
\hline For & 4 & 5.10 & 5.28 & 96.7 & 483.4 & 70.8 \\
\hline Ind & 2 & 2.55 & 0.96 & 36.9 & 0.0 & 60.1 \\
\hline Mit & 1 & 1.28 & 2.38 & 90.9 & 0.0 & 43.6 \\
\hline Mow & 7 & 8.93 & 0.45 & 55.4 & 54.7 & 74.0 \\
\hline Old & NA & NA & NA & NA & NA & NA \\
\hline Park & NA & NA & NA & NA & NA & NA \\
\hline Pond & NA & NA & NA & NA & NA & NA \\
\hline Res & 14 & 17.86 & 1.09 & 47.9 & 130.3 & 51.4 \\
\hline Road & 5 & 6.38 & 1.38 & 115.4 & 51.5 & 53.5 \\
\hline Wway & 1 & 1.28 & 0.35 & 183.9 & 0.0 & 52.5 \\
\hline Wet & NA & NA & NA & NA & NA & NA \\
\hline
\end{tabular}

$\mathrm{Ag}=$ Agriculture, Const $=$ Construction, For $=$ Forest, Ind $=$ Industrial, Mit $=$ Mitigation wetland Mow $=$ Mowed grass, Old $=$ Oldfield, Res $=$ Residential, $\mathbf{W}$ way $=$ Waterway, Wet $=$ Wetland \# Patches = number of patches in the landscape, $\mathrm{PD}=$ patch density (\# patches $/ 100$ ha)

$C A=$ mean patch area $\left(m^{2}\right)$ for land use, Gyrate $=$ radius of gyration $(m)$

Proxim = proximity index (unitless), $\mathrm{II}=$ interspersion and juxtaposition index (\%) 
Table L. 1 continued

\begin{tabular}{|c|c|c|c|c|c|c|}
\hline \multicolumn{7}{|c|}{ Project \#5a (Lombardo North) } \\
\hline Land Use & \# Punces & PD & CA & Gymate & Proxing & UI \\
\hline $\mathrm{Ag}$ & 6 & 7.76 & 2.74 & 62.0 & 40.6 & 41.2 \\
\hline Const & NA & NA & NA & NA & NA & NA \\
\hline For & 5 & 6.47 & 5.63 & 109.4 & 469.9 & 68.4 \\
\hline Ind & NA & NA & NA & NA & NA & NA \\
\hline Mit & 4 & 5.17 & 0.37 & 27.6 & 8.3 & 10.3 \\
\hline Mow & 1 & 129 & 0.29 & 21.8 & 0.0 & 0.0 \\
\hline Old & 2 & 2.59 & 0.86 & 36.4 & 0.0 & 47.1 \\
\hline Park & NA & NA & NA & NA & NA & NA \\
\hline Pond & 1 & 1.29 & 0.08 & 11.5 & 0.0 & 25.2 \\
\hline Res & 3 & 3.88 & 2.57 & 123.0 & 4032 & 51.8 \\
\hline Road & 1 & 1.29 & 0.73 & 188.8 & 0.0 & 14.3 \\
\hline Wway & 1 & 1.29 & 3.72 & 264.8 & 0.0 & 14.8 \\
\hline Wet & 2 & 2.59 & 0.60 & 38.0 & 0.0 & 13.9 \\
\hline \multicolumn{7}{|c|}{ Project \#5b (Lombardo South) } \\
\hline Land Use & \# Patches & PD & $\mathbf{C A}$ & Gyrate & Proxim & UI \\
\hline Ag & 4 & 4.85 & 1.64 & 51.5 & 109.3 & 60.3 \\
\hline Const & 2 & 2.43 & 0.70 & 38.1 & 3.4 & 46.4 \\
\hline For & 4 & 4.85 & 1.99 & 76.8 & 1.9 & 60.4 \\
\hline Ind & 2 & 2.43 & 1.86 & 51.1 & 0.5 & 58.6 \\
\hline Mit & 1 & 121 & 7.12 & 108.3 & 0.0 & 47.2 \\
\hline Mow & 2 & 2.43 & 0.66 & 35.8 & 0.0 & 45.1 \\
\hline Old & 4 & 4.85 & 5.07 & 92.8 & 144.8 & 86.9 \\
\hline Park & 1 & 121 & 3.93 & 82.9 & 0.0 & 28.9 \\
\hline Pond & 9 & 10.91 & 0.46 & 23.4 & 3.7 & 40.4 \\
\hline Res & 4 & 4.85 & 2.69 & 79.5 & 732.8 & 71.6 \\
\hline Road & 1 & 121 & 0.80 & 202.3 & 0.0 & 51.3 \\
\hline Wway & NA & NA & NA & NA & NA & NA \\
\hline Wet & 3 & 3.64 & 0.48 & 33.8 & 0.6 & 59.5 \\
\hline \multicolumn{7}{|c|}{$\begin{array}{l}\text { Ag = Agriculture, Const = Construction, For = Forest, ind = Industrial, Mit = Mitigation wetland } \\
\text { Mow = Mowed grass, Old = Oldfield, Res = Residential, Wway = Waterway, Wet = Wetland } \\
\text { \# Patches = number of patches in the landscape, PD = patch density (\# patches } 100 \text { ha) } \\
\text { CA = mean patch area }\left(\mathrm{m}^{2} \text { ) for land use, Gyrate = radius of gyration (m) }\right. \\
\text { Proxim = proximity index (unitless), IJI = interspersion and juxtaposition index (\%) }\end{array}$} \\
\hline
\end{tabular}


Table L. 1 continued

\begin{tabular}{|c|c|c|c|c|c|c|}
\hline \multicolumn{7}{|c|}{ Project \#6 (OTC) } \\
\hline Land Use & \# Patches & PD & $\mathbf{C A}$ & Gyrute & Proxin & $\mathbf{U}$ \\
\hline $\mathrm{Ag}$ & NA & NA & NA & NA & NA & NA \\
\hline Const & 4 & 7.75 & 0.96 & 34.2 & 71.6 & 69.7 \\
\hline For & 7 & 13.57 & 1.55 & 58.5 & 241.0 & 68.7 \\
\hline Ind & 3 & 5.82 & 0.24 & 21.0 & 0.8 & 29.1 \\
\hline Mit & 1 & 1.94 & 0.77 & 39.9 & 0.0 & 22.3 \\
\hline Mow & 5 & 9.69 & 0.55 & 35.9 & 29.4 & 64.0 \\
\hline Old & 10 & 19.39 & 0.96 & 41.1 & 133.3 & 71.5 \\
\hline Park & 6 & 11.63 & 1.30 & 70.1 & 186.1 & 72.2 \\
\hline Pond & NA & NA & NA & NA & NA & NA \\
\hline Res & $\mathbf{N A}$ & NA & NA & NA & NA & NA \\
\hline Road & 3 & 5.82 & 0.40 & 62.1 & 0.5 & 71.5 \\
\hline Wway & 3 & 5.82 & 1.04 & 111.3 & 160.1 & 58.2 \\
\hline Wet & 1 & 1.94 & 0.49 & 35.1 & 0.0 & $\mathbf{4 4 . 6}$ \\
\hline \multicolumn{7}{|c|}{ Project \#7 (Twinsburg) } \\
\hline Land Use & \# Patches & PD & $\mathbf{C A}$ & Gyrate & Proxim & UI \\
\hline Ag & NA & NA & NA & NA & NA & NA \\
\hline Const & 2 & 2.55 & 0.60 & 38.6 & 0.2 & 40.5 \\
\hline For & 8 & 10.21 & 4.38 & 84.9 & 1011.5 & 81.6 \\
\hline Ind & NA & NA & NA & NA & NA & NA \\
\hline Mit & 1 & 1.28 & 2.59 & 79.1 & 0.0 & 39.9 \\
\hline Mow & 3 & 3.83 & 0.50 & 64.7 & 0.1 & 31.0 \\
\hline Old & 5 & 6.38 & 1.45 & 64.4 & 101.9 & 80.3 \\
\hline Park & 1 & 1.28 & 2.59 & 61.7 & 0.0 & 3.7 \\
\hline Pond & 2 & 2.55 & 0.12 & 13.4 & 0.0 & 27.8 \\
\hline Res & 5 & 6.38 & 1.31 & 40.9 & 38.2 & 40.2 \\
\hline Road & 2 & 2.55 & 0.67 & 200.2 & 0.4 & 52.1 \\
\hline Wway & 1 & 1.28 & 0.08 & 14.0 & 0.0 & 0.0 \\
\hline Wet & 4 & 5.10 & 0.26 & 29.3 & 5.1 & 19.6 \\
\hline $\begin{array}{l}\text { Ag = Agri } \\
\text { Mow = Mo } \\
\text { \# Patches } \\
\text { CA = mear } \\
\text { Proxim = }\end{array}$ & $\begin{array}{l}\text { nst }=\text { Const } \\
\text { Old = Oldf } \\
\text { f patches in } \\
\text { a }\left(\mathrm{m}^{2}\right) \text { for la } \\
\text { ndex (unitle }\end{array}$ & $\begin{array}{l}\text { For }=\bar{F} \\
\text { es = Res } \\
\text { dscape, } \\
\text { Gyrate } \\
=\text { inters }\end{array}$ & $\begin{array}{l}\text { Ind }=1 \\
\text { al, Wu } \\
\text { patch } \\
\text { us of } g \\
\text { a and } j\end{array}$ & $\begin{array}{l}\text { ial, Mit } \\
\text { Naterway } \\
\text { (\# patch } \\
\text { n (m) } \\
\text { sition in }\end{array}$ & $\begin{array}{l}\text { fion weti } \\
\text { = Wetland } \\
\text { ha) }\end{array}$ & \\
\hline
\end{tabular}


Table L.1 continued

\begin{tabular}{|c|c|c|c|c|c|c|}
\hline \multicolumn{7}{|c|}{ Project \#8 (Whitlach) } \\
\hline Land Use & \# Patches & PD & $\mathrm{CA}$ & Gyrate & Proxin & IJ \\
\hline $\mathbf{A g}$ & NA & NA & NA & NA & NA & NA \\
\hline Const & 2 & 3.26 & 2.74 & 62.3 & 0.6 & 59.8 \\
\hline For & 15 & 24.45 & 1.32 & 45.0 & 534.7 & 75.1 \\
\hline Ind & 6 & 9.78 & 1.10 & 41.9 & 146.1 & 64.6 \\
\hline Mit & 2 & 3.26 & 0.38 & 31.2 & 25.8 & 0.0 \\
\hline Mow & 8 & 13.04 & 0.49 & 35.4 & 37.7 & 74.3 \\
\hline Old & 9 & 14.67 & 0.47 & 32.3 & 6.1 & 59.3 \\
\hline Park & NA & NA & NA & NA & NA & NA \\
\hline Pond & 1 & 1.63 & 0.03 & 8.1 & 0.0 & 0.0 \\
\hline Res & 6 & 9.78 & 0.42 & 21.0 & 13.5 & 73.1 \\
\hline Road & 1 & 1.63 & 0.95 & 158.6 & 0.0 & 61.3 \\
\hline Wway & 1 & 1.63 & 1.45 & 207.3 & 0.0 & 26.3 \\
\hline Wet & NA & NA & NA & NA & NA & NA \\
\hline $\begin{array}{l}\text { Ag = Agri } \\
\text { Mow = M } \\
\text { \# Patches } \\
\text { CA = mea } \\
\text { Proxim = }\end{array}$ & $\begin{array}{l}\text { nst }=\text { Constr } \\
\text { Old = Oldf } \\
\text { f patches in } \\
\left(\mathrm{m}^{2}\right) \text { for las } \\
\text { dex (unitle }\end{array}$ & $\begin{array}{l}\text { For }=1 \\
\text { es = Re } \\
\text { dscape, } \\
\text { Gyrate } \\
=\text { inters }\end{array}$ & $\begin{array}{l}\text { Ind = } \\
\text { al, Wv } \\
\text { patch } \\
\text { us of } 8 \\
n \text { and } j\end{array}$ & $\begin{array}{l}\text { jal, Mit = } \\
\text { Naterway } \\
\text { (\# patch } \\
\text { (m) } \\
\text { sition in }\end{array}$ & $\begin{array}{l}\text { Mow = Mowed grass, Old = Oldfield, Res = Residential, Wway = Waterway, Wet }=\text { Wetland } \\
\text { \# Patches = number of patches in the landscape, } P D=\text { patch density (\# patches } 100 \text { ha) }\end{array}$ & \\
\hline
\end{tabular}




\begin{tabular}{|c|c|c|c|}
\hline \multicolumn{4}{|c|}{ Project \#1 (I-80 Bridges) } \\
\hline Agriculture & NA & NA & NA \\
\hline Construction & 6 & 2.57 & 57.1 \\
\hline Forest & 22 & 7.76 & 78.6 \\
\hline Industrial & 6 & 1.09 & 52.8 \\
\hline Mitigation & 2 & 0.68 & 54.6 \\
\hline Mowed & 42 & 0.56 & 71.6 \\
\hline Oldfield & 43 & 1.27 & 72.6 \\
\hline Park & NA & NA & NA \\
\hline Pond & 1 & 0.08 & 30.3 \\
\hline Residential & 28 & 2.04 & 42.2 \\
\hline Road & 8 & 2.06 & 71.6 \\
\hline Waterway & 4 & 4.00 & 55.2 \\
\hline Wetland & 10 & 1.90 & 56.7 \\
\hline \multicolumn{4}{|c|}{ Project \#2 (Four Seasons) } \\
\hline Land Use & \# Patches & $\mathrm{CA}$ & IJI \\
\hline Agriculture & 3 & 7.14 & 61.1 \\
\hline Construction & 9 & 1.58 & 50.5 \\
\hline Forest & 31 & 5.21 & 70.7 \\
\hline Industrial & NA & NA & NA \\
\hline Mitigation & 2 & 0.52 & 30.8 \\
\hline Mowed & 25 & 1.21 & 72.1 \\
\hline Oldfield & 13 & 1.77 & 63.6 \\
\hline Park & NA & NA & NA \\
\hline Pond & 6 & 0.17 & 17.3 \\
\hline Residential & 31 & 3.87 & 58.3 \\
\hline Road & 5 & 3.32 & 50.6 \\
\hline Waterway & NA & NA & NA \\
\hline Wetland & 2 & 3.10 & 39.9 \\
\hline
\end{tabular}

\# Patches = number of patches in the landscape, $C A=$ mean patch area $\left(m^{2}\right)$ for land use, $I J I=$ interspersion and juxtaposition index (\%)

Continued

Table L.2 Landscape data for $1000 \mathrm{~m}$ landscapes. 
Table L. 2 continued

\begin{tabular}{|c|c|c|c|}
\hline \multicolumn{4}{|c|}{ Project \#3 (Harvard Road) } \\
\hline Agriculture & NA & NA & NA \\
\hline Construction & 11 & 2.32 & 63.6 \\
\hline Forest & 21 & 3.75 & 65.4 \\
\hline Industrial & 7 & 13.07 & 71.2 \\
\hline Mitigation & 1 & 1.45 & 29.1 \\
\hline Mowed & 12 & 2.61 & 76.9 \\
\hline Oldfield & 19 & 2.63 & 76.5 \\
\hline Park & NA & NA & NA \\
\hline Pond & 4 & 0.27 & 49.3 \\
\hline Residential & 9 & 6.69 & 60.2 \\
\hline Road & 5 & 11.16 & 73.7 \\
\hline Waterway & NA & NA & NA \\
\hline Wetland & 5 & 0.06 & 42.0 \\
\hline \multicolumn{4}{|c|}{ Project \#4 (Kerruish) } \\
\hline Land Use & \# Patches & CA & IJI \\
\hline Agriculture & NA & NA & NA \\
\hline Construction & 3 & 3.18 & 58.3 \\
\hline Forest & 11 & 4.64 & 81.3 \\
\hline Industrial & 12 & 6.90 & 33.0 \\
\hline Mitigation & 1 & 2.39 & 37.9 \\
\hline Mowed & 11 & 0.98 & 69.4 \\
\hline Oldfield & 3 & 0.74 & 44.3 \\
\hline Park & 1 & 16.64 & 44.1 \\
\hline Pond & NA & NA & NA \\
\hline Residential & 71 & 2.38 & 31.8 \\
\hline Road & 6 & 10.40 & 44.3 \\
\hline Waterway & 2 & 0.69 & 47.8 \\
\hline Wetland & NA & NA & NA \\
\hline \multicolumn{4}{|c|}{ Project \#5a (Lombardo North) } \\
\hline Land Use & \# Patches & $\mathrm{CA}$ & IJI \\
\hline Agriculture & 12 & 5.44 & 54.0 \\
\hline Construction & 2 & 1.53 & 40.6 \\
\hline Forest & 18 & 8.64 & 76.0 \\
\hline Industrial & NA & NA & NA \\
\hline Mitigation & 5 & 0.30 & 10.3 \\
\hline Mowed & 9 & 1.39 & 63.6 \\
\hline Oldfield & 13 & 2.91 & 49.1 \\
\hline Park & 1 & 0.12 & 5.4 \\
\hline Pond & 19 & 0.24 & 53.9 \\
\hline Residential & 23 & 4.99 & 62.1 \\
\hline Road & 6 & 1.00 & 32.2 \\
\hline Waterway & 1 & 9.56 & 14.0 \\
\hline Wetland & 3 & 0.49 & 9.7 \\
\hline
\end{tabular}

\# Patches $=$ number of patches in the landscape, $\mathrm{CA}=$ mean patch area $\left(\mathrm{m}^{2}\right)$ for land use, $\mathrm{II}=$ interspersion and juxtaposition index (\%) 
Table L. 2 continued

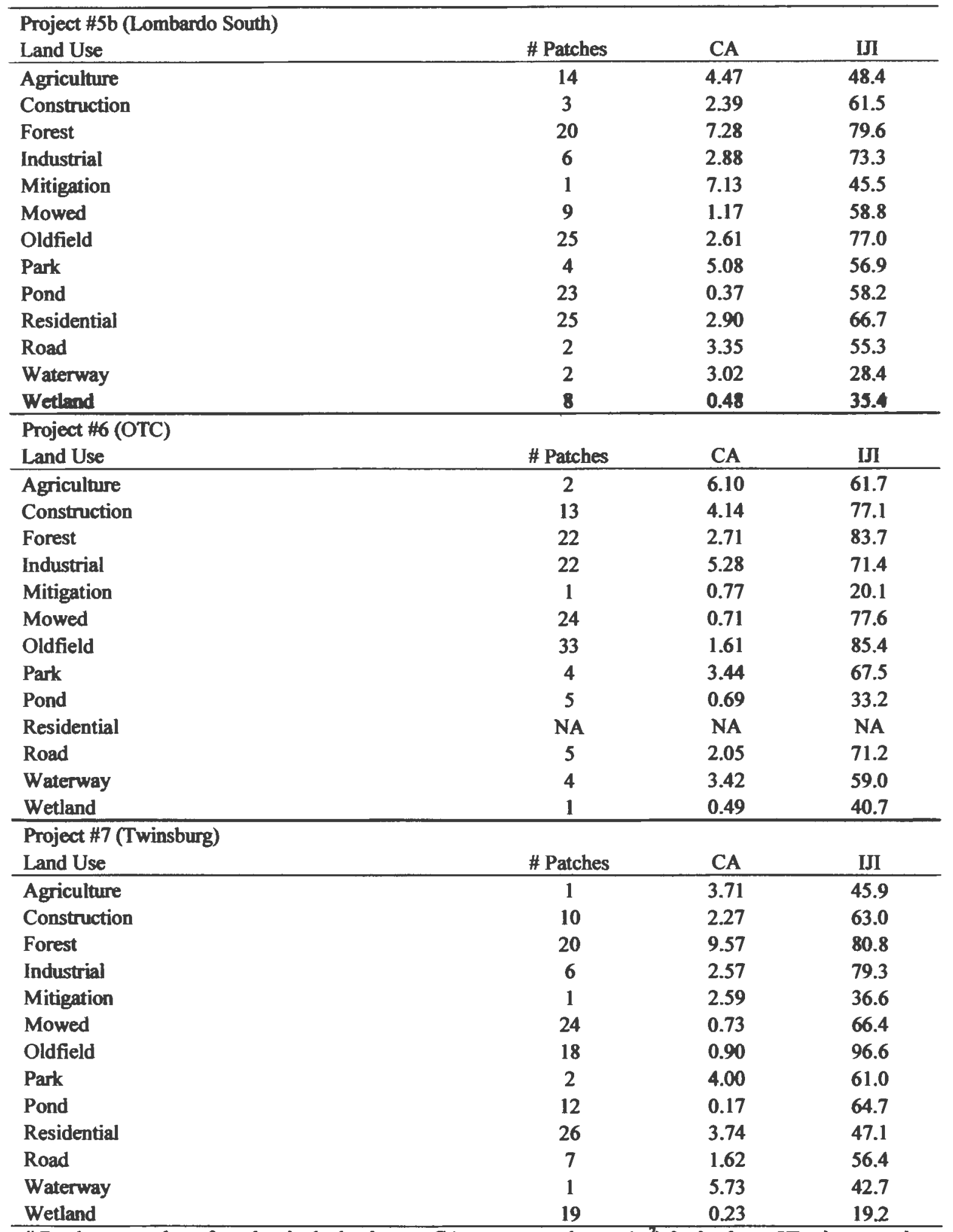

\# Patches = number of patches in the landscape, $\mathbf{C A}=$ mean patch area $\left(\mathrm{m}^{2}\right)$ for land use, $\mathbf{I I}=$ interspersion and juxtaposition index (\%) 
Table L. 2 continued

\begin{tabular}{lccc}
\hline Project \#8 (Whitlach) & \# Patches & CA & IJ \\
Land Use & NA & NA & NA \\
\hline Agriculture & 10 & 1.89 & 71.8 \\
Construction & 42 & 3.58 & 79.1 \\
Forest & 21 & 2.21 & 66.6 \\
Industrial & 2 & 0.39 & 0.0 \\
Mitigation & 46 & 0.88 & 70.2 \\
Mowed & 36 & 1.14 & 66.7 \\
Oldfield & 2 & 1.31 & 50.0 \\
Park & 8 & 0.44 & 56.8 \\
Pond & 26 & 1.50 & 58.4 \\
Residential & 4 & 4.89 & 63.5 \\
Road & 1 & 4.48 & 41.0 \\
Waterway & 10 & 0.17 & 42.0 \\
Wetland & & & \\
\hline
\end{tabular}

\# Patches $=$ number of patches in the landscape, $C A=$ mean patch area $\left(\mathrm{m}^{2}\right)$ for land use, $I J I=$ interspersion and juxtaposition index (\%) 


\begin{tabular}{cccc}
\hline $\begin{array}{c}300 \text { meter landscapes } \\
\text { Project \# }\end{array}$ & Human & Natural & Water \\
\hline 1 & 18.5 & 68.0 & 13.5 \\
2 & 62.3 & 35.4 & 2.4 \\
3 & 64.6 & 32.8 & 2.7 \\
4 & 59.7 & 35.7 & 4.6 \\
$5 \mathrm{a}$ & 40.9 & 48.6 & 10.5 \\
$5 \mathrm{~b}$ & 35.4 & 46.3 & 18.3 \\
6 & 20.6 & 68.7 & 10.7 \\
7 & 17.8 & 75.5 & 6.7 \\
8 & 42.6 & 52.5 & 4.9 \\
\hline 1000 meter landscapes & & & \\
Project \# & Human & Natural & 9.6 \\
\hline 1 & 31.3 & 59.2 & 2.1 \\
2 & 51.2 & 46.7 & 0.7 \\
3 & 66.8 & 32.5 & 0.9 \\
4 & 81.9 & 17.1 & 4.2 \\
$5 \mathrm{a}$ & 48.9 & 46.9 & 5.9 \\
$5 b$ & 40.8 & 53.3 & 5.2 \\
6 & 59.1 & 35.7 & 3.7 \\
7 & 42.2 & 54.1 & 2.8 \\
\hline 8 & 44.5 & 52.6 & \\
\hline
\end{tabular}

Human land uses = agriculture, construction, industrial, mowed, residential, road

Natural land uses $=$ forest, oldfield, park

Water = mitigation wetland, pond, waterway, wetland

Table L.3 Percent of human, natural, and surface water land uses on mitigation landscapes. 
APPENDIX M

RESTORATION POTENTIAL DATA 


\begin{tabular}{ccc}
\hline Project \# & Compliance & Restoration Potential \\
\hline 1 & -5.46 & 33.9 \\
2 & -48.90 & 0 \\
3 & 52.99 & 13.7 \\
4 & 106.45 & 17.2 \\
6 & 78.05 & 10.1 \\
7 & 49.61 & 0 \\
8 & -55.90 & 39.9 \\
9 & -19.13 & 30.6 \\
10 & -45.24 & 24.1 \\
11 & -41.70 & 32.2 \\
12 & -2.95 & 44.6 \\
\hline
\end{tabular}

Table M.1 Compliance (\% deviation from required mitigation) and restoration potential data. 